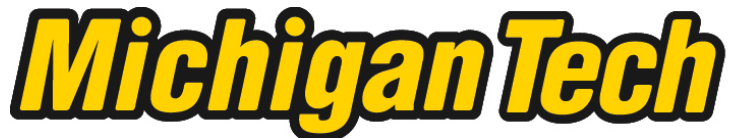 \\ Michigan Technological University Create the Future Digital Commons @ Michigan Tech
}

\section{The impact of balsamo (Myroxylon balsamum L. Harms) on coffee yield and household income in El Balsamar, El Salvador}

Evan A. Anderson

Michigan Technological University

Follow this and additional works at: https://digitalcommons.mtu.edu/etds

Part of the Forest Sciences Commons

Copyright 2012 Evan A. Anderson

\section{Recommended Citation}

Anderson, Evan A., "The impact of balsamo (Myroxylon balsamum L. Harms) on coffee yield and household income in El Balsamar, El Salvador", Master's Thesis, Michigan Technological University, 2012. https://doi.org/10.37099/mtu.dc.etds/158

Follow this and additional works at: https://digitalcommons.mtu.edu/etds

8 Part of the Forest Sciences Commons 
THE IMPACT OF BALSAMO (MYROXYLON BALSAMUM L. Harms) ON COFFEE YIELD AND HOUSEHOLD INCOME IN EL BALSAMAR, EL SALVADOR

\title{
By
}

Evan A. Anderson

\begin{abstract}
A THESIS
Submitted in partial fulfillment of the requirements for the degree of MASTER OF SCIENCE

(Forestry)
\end{abstract}

MICHIGAN TECHNOLOGICAL UNIVERSITY

2012

(C)2012 Evan A. Anderson 
This thesis, "The Impact of Balsamo (Myroxylon Balsamum L. Harms) on Coffee Yield and Household Income in El Balsamar, El Salvador," is hereby approved in partial fulfillment of the requirements of the Degree of MASTER OF SCIENCE IN FORESTRY.

School of Forest Resources and Environmental Science

Signatures:

Thesis Advisor

Dr. Blair Orr

Dean

Dr. Margaret R. Gale

Date 


\section{Table of Contents}

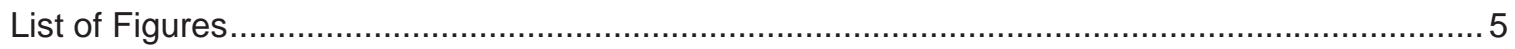

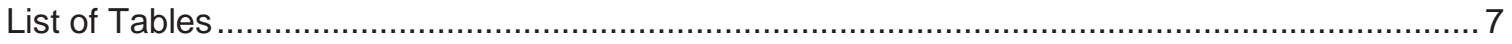

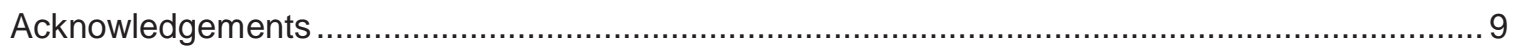

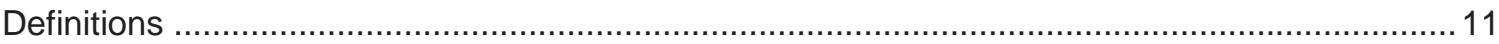

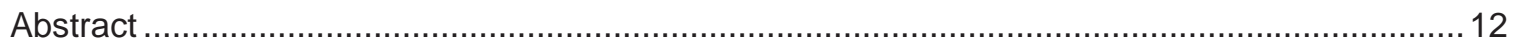

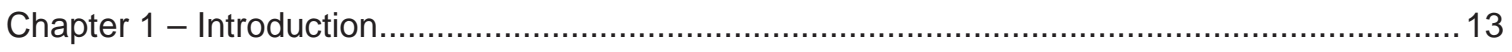

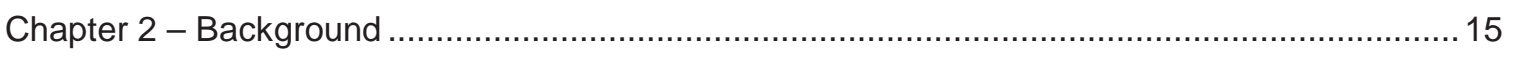

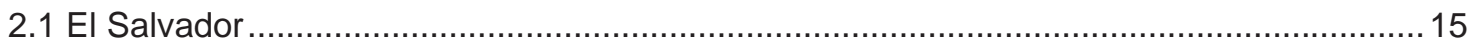

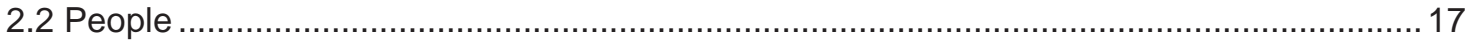

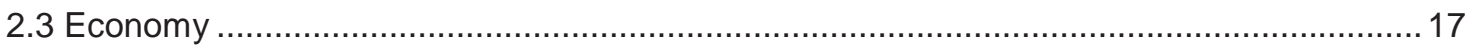

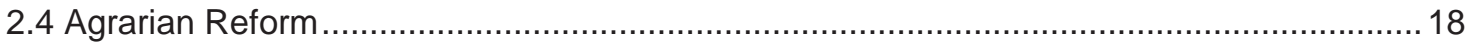

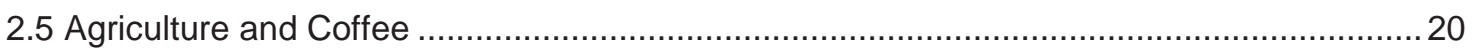

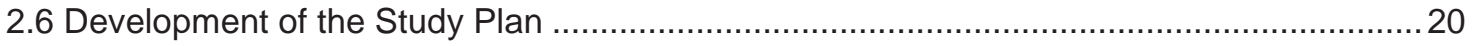

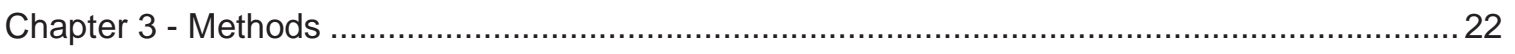

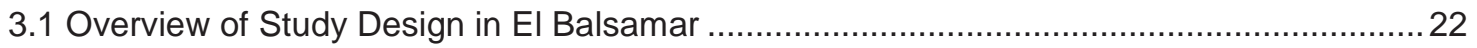

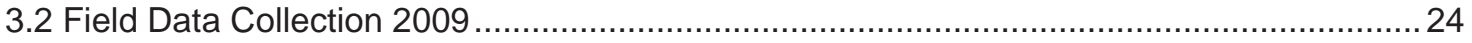

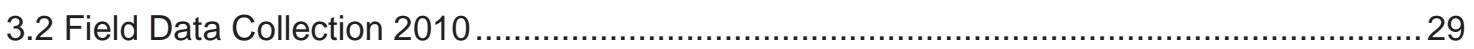

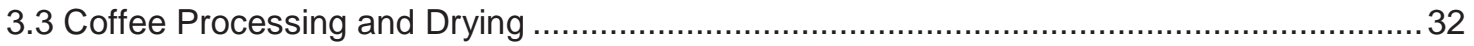

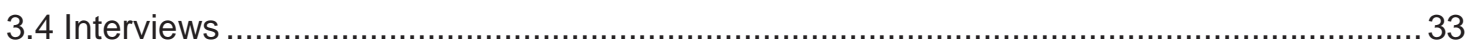

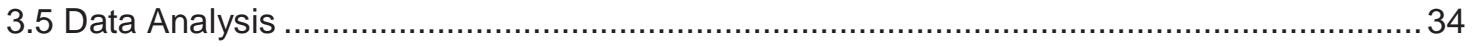

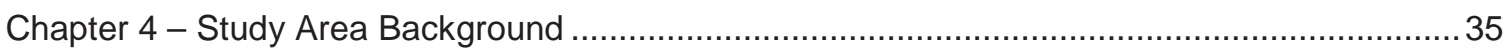

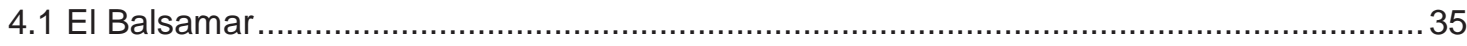

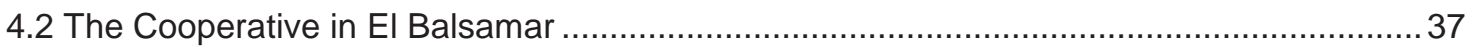

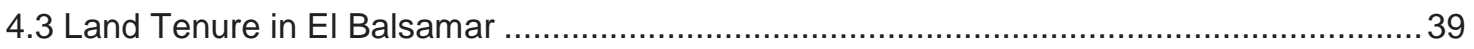

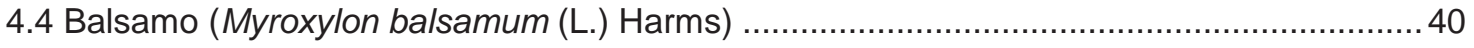

4.5 Management History of the Balsamo Tree in El Balsamar .............................................. 41 


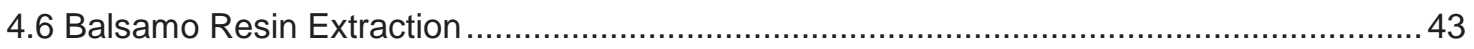

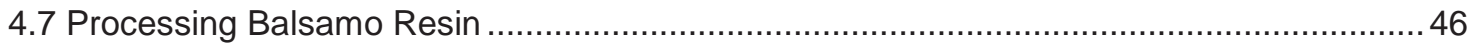

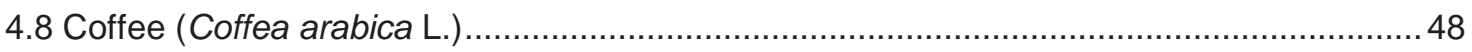

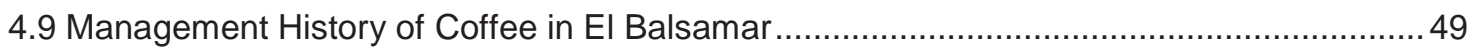

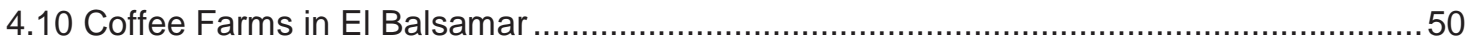

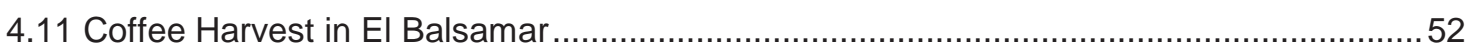

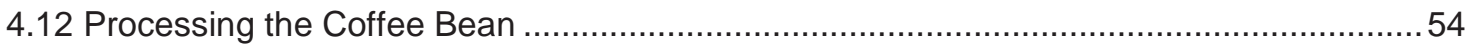

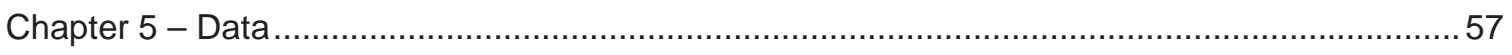

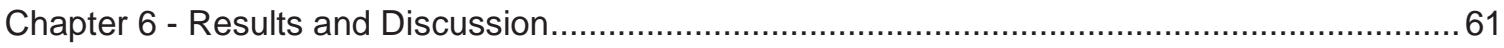

6.1 Coffee Yield Under Balsamo and Non Balsamo Cover Types ......................................... 62

6.2 Differences in Coffee Yield Under Both Cover Types......................................................64

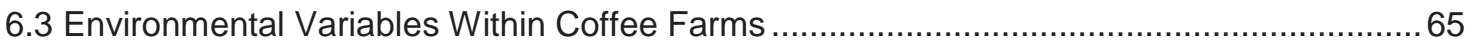

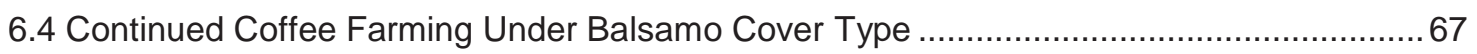

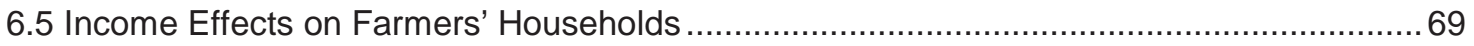

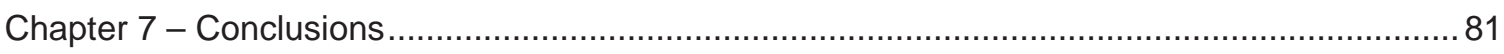

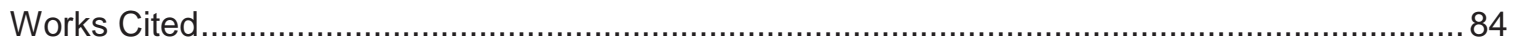

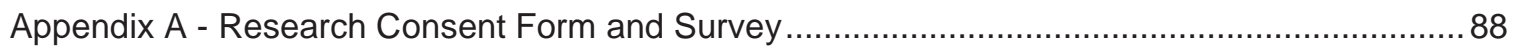

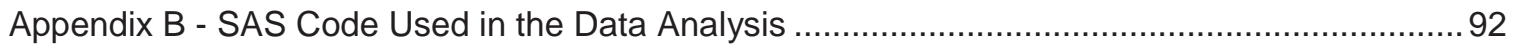

Appendix C - Tabular Data Set of Balsamo/Non Balsamo Cover Type Data Set ........................93

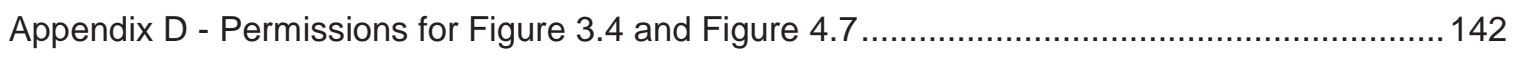

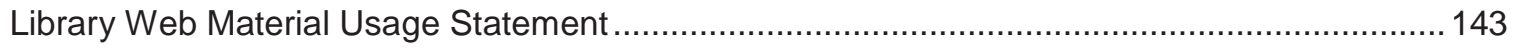

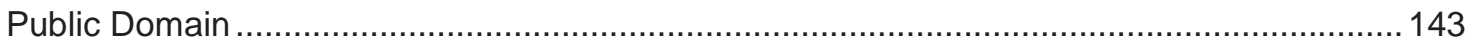




\section{List of Figures}

Figure 2.1. Map of Central America with El Salvador in the center

(University of Texas). 15

Figure 2.2. The administrative departments of El Salvador.

Data Layers by Evan Anderson.

Figure 3.1. Sample design for one coffee farm in the study.

Created by Evan Anderson.

Figure 3.2. Community member harvesting coffee from one

of the coffee trees. Photo by Evan Anderson.

Figure 3.3. Weighing the harvested coffee. Photo by Evan Anderson.

Figure 3.4. Recording coffee tree measurements.

Photo by Steve Anderson.

Figure 3.5. Coffee samples drying on patio. Photo by Evan Anderson 32

Figure 4.1. Farmer with maize and sorghum crops.

Photo by Evan Anderson... 36

Figure 4.2. Bean crop. Photo by Evan Anderson. . . 36

Figure 4.3. Rice crop. Photo by Evan Anderson

Figure 4.4. Coffee farm after the weeds have been cut.

Photo by Evan Anderson. 38

Figure 4.5. Hachon catching fire before used to burn balsamo tree.

Photo by Evan Anderson. 44 
Figure 4.6. Farmer burning balsamo tree for resin extraction.

Photo by Evan Anderson... 45

Figure 4.7. Twisting the sack of bark in the torcedera.

Photo by Steve Anderson.

Figure 4.8. Balsamo resin from the bark shavings draining from a sack after being twisted in the torcedera. Photo by Evan Anderson 47

Figure 4.9. Separating the balsamo resin from water. Photo by Evan Anderson. 48

Figure 4.10. The bourbon variety in the coffee farms.

Photo by Evan Anderson.

Figure 4.11. Canastas with coffee beans. One filled canasta is equal to $25 \mathrm{lbs}$. Photo by Evan Anderson 53

Figure 4.12. Separating coffee skin from the bean in the pulper.

Photo by Evan Anderson... 54

Figure 4.13. Coffee beans with parchment emptied into large concrete tank.

Photo by Evan Anderson.... 55

Figure 4.14. Coffee drying on the patio. Photo by Evan Anderson... 56

Figure 4.15. Coffee in sacks ready to be transported to exporter.

Photo by Evan Anderson....... 56

Figure 6.1. Coffee farm with balsamo tree as dominant overstory species.

Photo by Evan Anderson... 62

Figure 6.2. Large diameter balsamo tree. Photo by Evan Anderson. 63

Figure 6.3. Average annual coffee prices (US cents/lb) from 1998 to

2011 (Data from: International Coffee Organization 2012) 70 


\section{List of Tables}

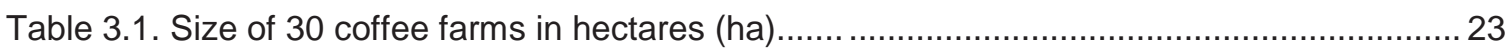

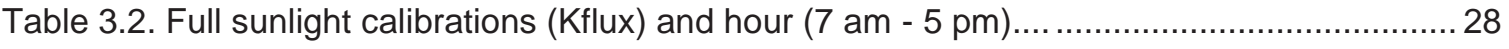

Table 3.3. Number of basal area points recorded in each farm............................................... 31

Table 4.1. Non balsamo cover type trees recorded in the 30 farms sampled

Listed are the common name, genus and species................................................... 51

Table 5.1. Mean and standard deviation of variable measured in balsamo and non balsamo cover types in year 2009. Standard deviations are

in parenthesis 58

Table 5.2. Mean and standard deviation of variables measured in balsamo and non balsamo cover types in year 2010. Standard deviations are in parenthesis. 59

Table 5.3. Mean and standard deviation of variables measured in balsamo and non balsamo cover types in both years. Standard deviations are in parenthesis.

Table 6.1. Monthly rain data $(\mathrm{mm})$ for 2009 and 2010 within a $17 \mathrm{~km}$ radius of El Balsamar.

Table 6.2. Mean coffee prices in El Salvador for 2009 - 2011 68

Table 6.3. Mean basic grain prices (US\$/quintal) in El Salvador in 2009 and 2010.

Standard deviations in parenthesis. Data source: Ministry of

Agriculture El Salvador 
Table 6.4. Total balsamo resin harvest yield (lb) and revenue earned

(price/lb in $2009=$ US $\$ 2.50,2010=$ US $\$ 6.00$ ) by the

cooperative in $2009 / 2010$ and $2010 / 2011$.

Table 6.5. Total coffee harvest yield (quintal $=101.2 \mathrm{lbs}$ ) and revenue

(price/101.2 lbs) the cooperative earned in 2009 and 2010.

.76

Table 6.6. Hypothetical revenue of coffee yield and balsamo resin in

2010 if coffee farms were converted to non balsamo

cover type compared to original revenue of 2010 .

78

Table 6.7. Hypothetical revenue of coffee yield and balsamo resin in

2010 if coffee farms were converted to balsamo cover type

compared to original revenue of $2010 \ldots$

78

Table C.1. Complete data set of field study balsamo

cover type 2009.

Table C.2. Complete data set of field study balsamo

cover type 2010

Table C.3. Complete data set of field study non balsamo

cover type 2009

Table C.4. Complete data set of field study non balsamo cover type 2010 129

Table C.5. Complete data set of basal area in 30 coffee farms 141 


\section{Acknowledgements}

Without the insightfulness, patience and support of my advisor, Dr. Blair Orr, I would not have arrived at this point. I am in great debt for how prepared Blair made me feel when doing my research, writing my thesis and succeeding as a Peace Corps Volunteer. The Master's International Program at Michigan Technological University is a diverse and special program and Blair is what makes it possible giving the opportunity to those who have interest in combining a Master's degree and Peace Corps. I thank you for all of the quick feedback and all of the small knickknacks you sent me while I served in El Salvador. Your guidance has made what seemed like an impossible adventure possible.

I would like to thank my family, especially my father and brother, Steve and Elliott, for your unconditional support during my time in El Salvador and your continued support finishing up my work at Michigan Tech. Your willingness to visit me was some of the most memorable moments during Peace Corps.

Thank you to my committee members, Dr. Jim Pickens, Dr. Andrew Burton and Dr. Alex Mayer. I respect all of you and your input and advice has meant a lot to me.

Thank you Nick Padowski and Dylan Chase for coming to my site to assist me with field work measurements. Without your assistance, field work would have been a longer and more painful process.

I would also like to thank my fellow housemates, who are RPCVs as well. Your mutual support this semester made my time here more productive. Our time up here in Houghton will be just as memorable as Peace Corps. 
Thank you as well Miriam Rios Sanchez who helped tremendously with the cultural barriers when starting my interviews. You helped translate my somewhat forward, uncomfortable questions into more culturally appropriate ones.

Finally I would like to thank all of my friends and family in El Balsamar. You all made three years go by much too quickly with all of your stories, jokes and love. I will never be able to thank you enough for what you have done for me. 


\section{Definitions}

Aroba- Twenty five pounds

Balsamera- Area where balsamo resin is processed

Canasta- Basket used to harvest coffee

Canton- Village

Caporal- Coffee foreman; assigns community members which rows to harvest coffee

Cuadrilla- Measurement of area (1 cuadrilla $=900 \mathrm{~m}^{2}$ plots $)$

Estoraque- Dried bark shavings used as incense to repel insects

Hachon- Bundle of splintered wood

Hacienda- The cooperative's estate

Juntas- different factions forming a single group

Maduro- Ripe

Manzana- Measurement of area $\left(1\right.$ manzana $\left.=7,000 \mathrm{~m}^{2}\right)$

Mozo- Paid assistant

Pañal-Piece of old cloth used to absorb balsamo resin

Patron- Private Landowner

Quincena- Fifteen working days

Raspador- Thick flat metal tool similar to a flat head screwdriver

Socio- Cooperative member

Torcedera- Device for extracting balsamo resin from the bark; located in the balsamera 


\section{Abstract}

El Balsamar is a community that relies upon coffee trees intercropped with the balsamo tree (Myroxylon balsamum L. Harms) for a substantial portion of household income. The balsamo tree is valued for its resin which is used as medicine in the community and sold commercially. Farmers believe that the shade from the balsamo tree decreases coffee yield compared to the shade from non balsamo species. Thirty coffee farms were studied, each set up as a paired plot. When cover type was balsamo, coffee yield was more likely to decrease. Plots with higher basal area were more likely to be balsamo cover type. As basal area increased, coffee yield decreased. Although coffee yield is lower under balsamo cover type, farmers still continue to plant and manage coffee under this cover type. Farmers accept a lower coffee yield because balsamo resin provides an important income source. Farmers rely on the community cooperative to provide them work to support their households. The cooperative relies on the farmers to provide the labor needed to harvest coffee and extract balsamo resin. 


\section{Chapter 1 - Introduction}

I joined Peace Corps in September 2008 as part of the Master's International program at Michigan Technological University. I was interested in doing my service in the Latin American Region because I had language background in Spanish and I thought my forestry skills would be better suited there because of my romanticized view of Latin America being heavily forested. When I found out my placement was in El Salvador, I was not familiar with its location in Central America. I later discovered that it was a heavily deforested country and I would be working more with agriculture and farmers than with forests and farmers. I was pleasantly surprised to find out that my Peace Corps site was forested with many tree varieties, the dominant tree being balsamo (Myroxylon balsamum L. Harms) which I was unfamiliar with at the time. I soon began to understand the cultural and economic importance the balsamo tree had on the community.

Within a year in my site, I realized I wanted my research to be based around the balsamo tree. After talking informally with farmers, I found out their two main sources of income in the community were the coffee harvest and balsamo resin extraction. I then thought to do a study relating to these two sources of income.

The purpose of this study is to determine if balsamo cover type decreases coffee yield compared to the coffee yield under non balsamo cover type. Farmers told me they believed balsamo cover type decreased coffee yield and that non balsamo cover types were better suited for higher coffee yield. 
Chapter Two gives a general background of El Salvador with a brief history of the country, people, economy, agrarian reform, agriculture, and coffee as an agricultural product.

Chapter Three describes the methods used in the study. It addresses field data collection in 2009 , field data collection in 2010, coffee processing and drying, interviews, and data analysis. It precedes the background chapter because some of the descriptive material in the background came from personal observation.

Chapter Four presents the study area background. It gives a general background of the community El Balsamar, the cooperative in El Balsamar, land tenure in El Balsamar, a description of the balsamo tree, management history of the balsamo tree in El Balsamar, balsamo resin extraction, processing balsamo resin, description of the coffee species, management history of coffee in El Balsamar, coffee farms in El Balsamar, coffee harvest in El Balsamar, and processing the coffee bean.

Chapter Five presents the data from this study.

Chapter Six provides the results and discussion of the study. It analyzes coffee yield under balsamo and non balsamo cover types, differences in coffee yield under both cover types, environmental variables within coffee farms, continued coffee farming under balsamo cover type, and income effects on farmers' households.

Chapter Seven presents conclusions that could be drawn from the study. In addition, it presents possible future studies in the community 


\section{Chapter 2 - Background}

\subsection{El Salvador}

Out of all the countries in Central America, El Salvador is the smallest covering an area of $20,041 \mathrm{~km}^{2}$, an area that is slightly smaller than the state of Massachusetts (CIA 2012). The country borders Guatemala to the west and Honduras to the north. El Salvador is the only country in Central America without a Caribbean coast line (Figure 2.1) (CIA 2012).

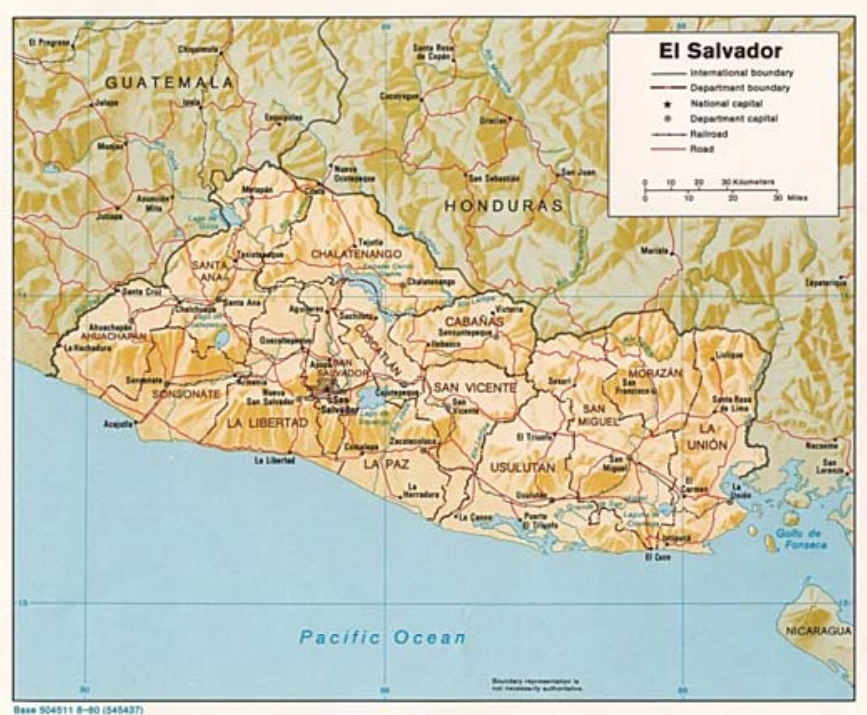

Figure 2.1. Map of Central America with El Salvador in the center (University of Texas 2012) 


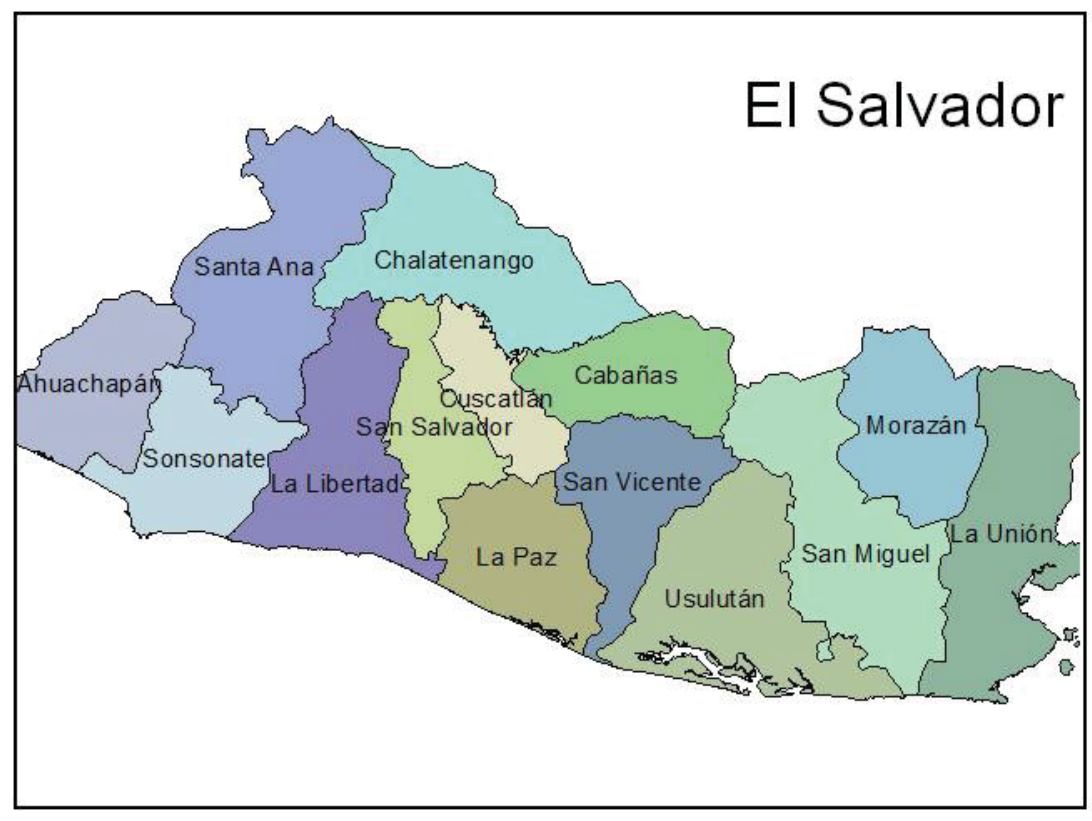

Figure 2.2. The administrative departments of El Salvador. Data Layers by Evan Anderson

The country is a republic made up of fourteen administrative departments:

Ahuachapán, Sonsonate, Santa Ana, Chalatenango, La Libertad, San Salvador, Cuscatlán, San Vicente, La Paz, Morazán, Cabañas, Usulután, San Miguel, and La Union (Figure 2.2). The country's capital is San Salvador (State Department 2012).

Since the country became independent from Spain on September 15, 1821, population growth and limited land availability have caused fighting among El Salvador's people and have affected development (Foley 1995). This culminated in 1980 when the country broke out into a war that lasted twelve years where approximately 75,000 lives were lost. In January 1992, a peace treaty was signed by the government and leftist rebels. The treaty put the military under civilian control and the leftist rebels formed their own political party to be able to participate in elections (State Department 2012). 


\subsection{People}

The original inhabitants of El Salvador were the Pipil, who were descendants of the Aztecs, Pocomames and Lencas (State Department 2012). These tribes inhabited the country for thousands of years before the Spanish invasion. Today, approximately $90 \%$ of the population is mestizo which is a mixed Amerindian and Spanish descent (Foley 1995). The other 9\% is white and $1 \%$ is Amerindian (CIA 2012).

The country is divided into four social classes, the oligarch who control the country's power and wealth, the middle class, landless peasants, and the urban poor (Foley 1995). Spanish is the official language with Nahua still spoken by some indigenous groups. Roman Catholism (57.1\%) and Protestant (21.2\%) are the two dominant religions in the country. Mormon (0.7\%), Jehovah's Witnesses (1.9\%), other religions (2.3\%) and those not affiliated with religious groups (16.8\%) make up the rest of the population (CIA 2012).

\subsection{Economy}

El Salvador has always been a country with an economy based upon agriculture. It changed dramatically after the colonization by the Spanish, who drove the Amerindians off their land to grow cash crops such as cacao, indigo and coffee. Although these cash crops were successful for the Salvadoran economy, they only benefited the wealthy 
landowners. The uneven distribution in wealth resulted in political instability and eventually the civil war (Foley 1995).

The end of the war brought major structural reforms that resulted in a strong economy during the 1990s. Reforms included trade liberalization, financial sector privatization, a comprehensive tax system and improvements in investment. The country converted from the colon to the US dollar in 2001 to help reduce inflation (State Department 2012).

Important export commodities include coffee, textiles and apparel, sugar, offshore assembly exports, ethanol, electricity, gold, chemicals, iron and steel manufacture. Citizens who have formal jobs work in agriculture (11.1\%), industry (30.1\%) and services (58.7\%). The unemployment rate is at 7.2\% (CIA 2012).

In El Salvador, 36.5\% of the population lives below the poverty line (CIA 2012). The number of Salvadorans living in the United States was estimated in 2007 as 1.5 million, 39,000 in Canada, 20,000 in Australia and 12,000 in Italy (MPI 2012). Salvadorans send remittances back home to their families. These remittances make up 17\% of the Salvadoran GDP (CIA 2012).

\subsection{Agrarian Reform}

Prior to the agrarian reform law, El Salvador's land was owned by wealthy landowners who displaced the rest of the population. Many of the displaced were living in extreme poverty. Over one half of the population was forced to migrate to work and search for temporary access to land to grow subsistence crops (Pelupessy 1997). 
Land use was forever changed in El Salvador with the introduction of coffee farming in the late nineteenth century. Coffee farming negatively affected the poor by completely abolishing common land tenure; all land then became privately owned. Large tracts of land were owned by single landowners, and temporary land use was arranged between the owner and the tenant (Browning 1983). A limited land reform was passed in 1976 to alleviate the pressure the landless were putting on the government. Less than $3 \%$ of the land was redistributed by the Institute of Agrarian Transformation to small and medium sized private landowners. Political organizations and the landless did not accept this limited reform and created a mixed military and civilian juntas (in this case two different groups that came together to form a single group). This group came to power and changed the structure of the economy by reducing the power of the wealthy and reallocating income and wealth to reduce the potential for a peasant uprising (Pelupessy 1997).

Agrarian reform was passed into law on March 6, 1980. The law's main objectives were to ease the potential for a peasant uprising. Land was seized from landowners with properties of 500 hectares or more. This land was redistributed among the permanent workers who would then form cooperatives of at least 25 members (Pelupessy 1997). The Institute of Agrarian Transformation compensated the landowners by purchasing the seized land and an "agrarian debt" was issued to cooperatives with interest (Browning 1983). The cooperatives had a 30-year period to repay the debt. Once the debt was paid, the cooperative would own the land.

Cooperatives had problems with this reform. Many members left the cooperatives, apprehensive about what the future might hold. Underemployment was an issue. About a 
quarter of the cooperatives had problems paying off the "agrarian debt" due to the civil war, torrential rains and drought (Pelupessy 1997).

\subsection{Agriculture and Coffee}

After the colonization of El Salvador by the Spanish, cash crops were planted to boost the economy. Three cash crops were planted: cacao, indigo and coffee. With fluctuations in the global economy with trading partners, El Salvador had to diversify its agricultural exports (Foley 1995). Today, the country's agricultural products are coffee, sugar, livestock, corn, poultry, and sorghum. The country has $68 \%$ arable land for cultivation or pasture for livestock (State Department 2012).

Coffee became a main export crop when synthetic dyes made indigo unprofitable during the mid 1800 s, and the country switched to large scale coffee bean production. During the 1990s there was an overproduction of coffee worldwide. El Salvador was involved in the Coffee Retention Plan that took place in 1993. This was an agreement among the world's coffee exporters to reduce the amount of coffee production which would boost prices. Even with reduced production, coffee continues to provide the country with a reliable source of export income (Foley 1995).

\subsection{Development of the Study Plan}

The study plan was developed beginning with an interest in the balsamo (Myroxylon balsamum L. Harms) tree and its relationship to coffee production. 
Community members managed the tree for personal use. In informal conversations farmers discussed the disadvantages of having a high concentration of balsamo trees; believed that the shade from the tree reduced coffee yield.

The study started with two key questions, first, are farmers correct in their belief that balsamo tree shade reduces coffee yield? And if so, why do they continue to plant coffee under the balsamo tree? Some underlying motivation kept farmers continuing to farm this way and it was soon observed that farmers put equal effort into managing balsamo and coffee. Both crops seemed to be of equal importance to the farmers.

Interviews were conducted with community members and the cooperative to understand the importance and the impacts balsamo production and coffee had on the community. The cooperative then started to play a more prominent role in the study. An underlying social-economic structure between the community and cooperative became one of the main aspects of the study along with the impacts balsamo cover type had on coffee yields. From there, an underlying relationship between the community and cooperative was studied. 


\section{Chapter 3 - Methods}

This chapter describes the methods used to perform the field data collection and data analysis for this study. Paired plots were located on coffee farms with each pair of plots on ecologically uniform sites except that one plot had a balsamo cover type and the other plot non balsamo cover type. Coffee trees within the plots were harvested and coffee weighed. Diameter and height of the coffee trees were recorded. Light measurements were recorded next to each tree. Basal area of the entire farm was also measured. Formal interviews were performed on management techniques for coffee and balsamo. Information about the local area was collected.

\subsection{Overview of Study Design in El Balsamar}

El Balsamar consists of forty coffee farms. Thirty were used in the study. Each farm was between 1.5 and 4 hectares (Table 3.1). Some farms were not used because they had already been harvested by community members or did not have both balsamo and non balsamo cover type. All farms were required to contain both balsamo and non balsamo cover types allowing for the paired plots. The study plots all contained the bourbon coffee variety and coffee tree density was the same in all plots.

In 2009, only 15 farms were measured. The small sample size was due to the low coffee yield for that year. In 2010, 30 coffee farms were sampled. More farms could not be sampled because some farms had already been harvested by community members. 
Other farms did not have the balsamo and non balsamo cover type together in the same farm. Figure 3.1 illustrates the sample design for one farm with balsamo and non balsamo cover type.

Table 3.1.

Size of 30 coffee farms in hectares (ha)

\begin{tabular}{|c|c|}
\hline Farm number & Size (ha) \\
\hline 1 & 4.0 \\
\hline 2 & 3.0 \\
\hline 3 & 2.0 \\
\hline 4 & 1.5 \\
\hline 5 & 2.0 \\
\hline 6 & 2.5 \\
\hline 7 & 2.8 \\
\hline 8 & 1.8 \\
\hline 9 & 1.5 \\
\hline 10 & 2.0 \\
\hline 11 & 2.0 \\
\hline 12 & 3.5 \\
\hline 13 & 1.5 \\
\hline 14 & 2.5 \\
\hline 15 & 2.5 \\
\hline 16 & 1.5 \\
\hline 17 & 2.0 \\
\hline 18 & 1.8 \\
\hline 19 & 2.5 \\
\hline 20 & 3.5 \\
\hline 21 & 2.8 \\
\hline 22 & 2.0 \\
\hline 23 & 2.0 \\
\hline 24 & 2.0 \\
\hline 25 & 3.0 \\
\hline 26 & 2.8 \\
\hline 27 & 1.5 \\
\hline 28 & 2.8 \\
\hline 29 & 2.8 \\
\hline 30 & 1.5 \\
\hline
\end{tabular}




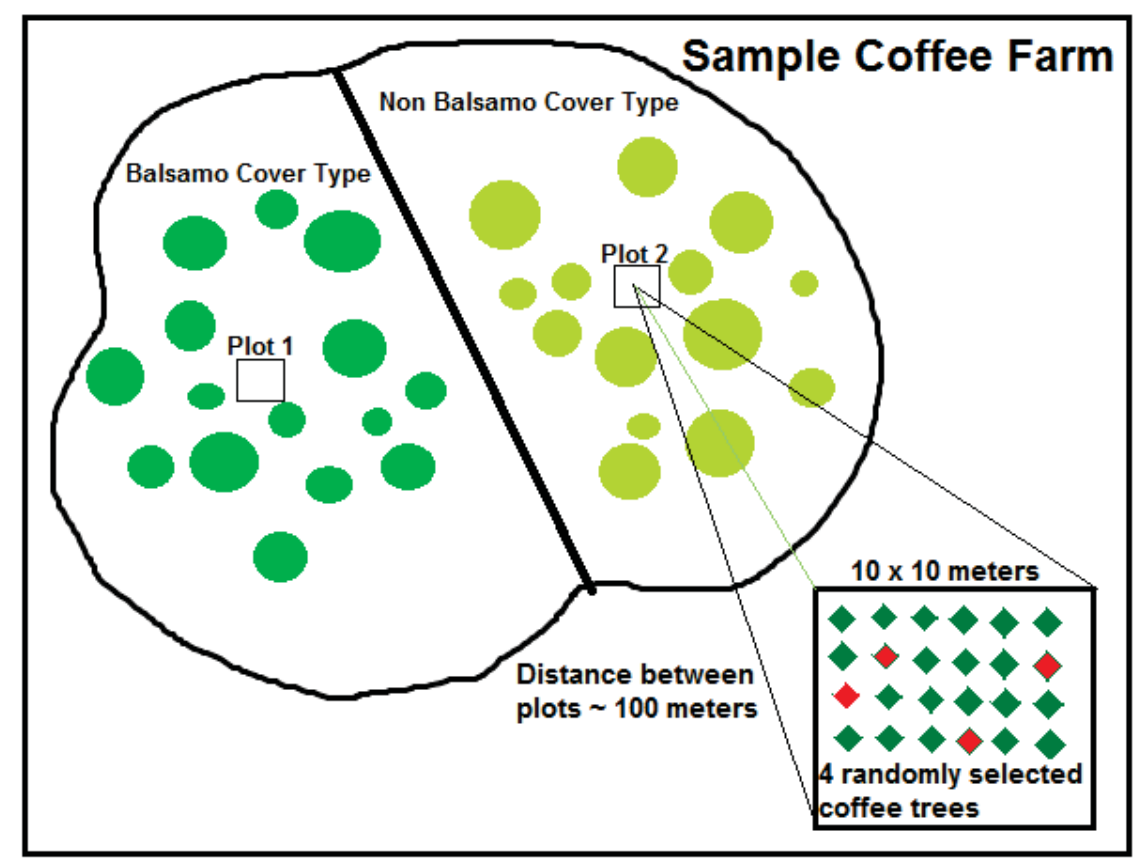

Figure 3.1. Sample design for one coffee farm in the study. Created by Evan Anderson

\subsection{Field Data Collection 2009}

In 2009 the study had 15 coffee farms. There was less rainfall in 2009, which decreased the yield of coffee. Some farms produced no coffee. In 2009 annual rainfall in the department of Sonsonate was $1951.4 \mathrm{~mm}$ and in 2010 the annual rainfall was 2719.2 mm (SNET 2011). The farms selected were those with coffee yield for the data collection of 2009. The plots within each farm were selected as ecologically uniform sites and one plot with balsamo cover type and the other with non balsamo cover type. Coffee trees were measured in a 10 meter by 10 meter area under each cover type. In each cover type plot, four coffee trees were randomly selected through a list of random numbers generated by Excel. The coffee trees selected to be harvested later were marked with 
colored ribbon. A community caporal (coffee foreman) was assigned to assist in each of the 15 farms because of his expertise of farm boundaries and locations of balsamo and non balsamo cover types (Boa et al. 2001).

Once the coffee harvest began, a second community member was hired along with the caporal to assist in the harvest. Plots were revisited by locating the plots of the cover type and colored ribbon marked on the 4 coffee trees. Some plots had to be relocated because coffee trees had their ribbons removed. Coffee was harvested into a basket carried by the picker (Figure 3.2), then weighed (kg/tree) using a Pesola $20 \mathrm{~kg}$ scale (PESOLA AG, Rebmattli 19, CH-6340 Baar, Switzerland) (Figure 3.3), the weight was recorded in a notebook, then the coffee was placed in a larger bag that would be given back to the cooperative after the harvest. 


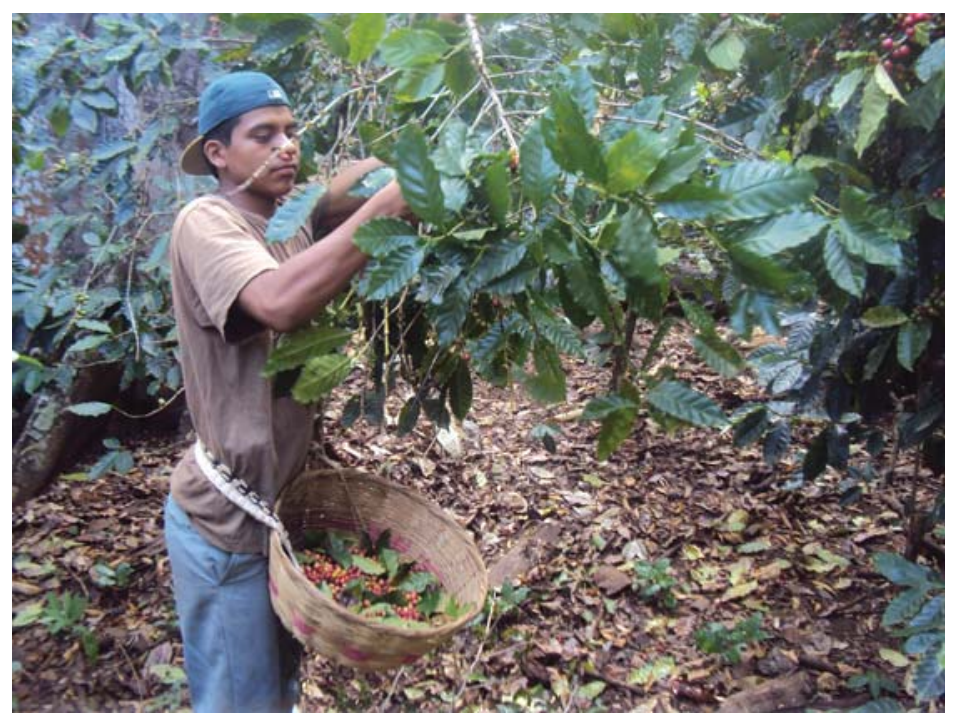

Figure 3.2. Community member harvesting coffee from one of the coffee trees. Photo by Evan Anderson

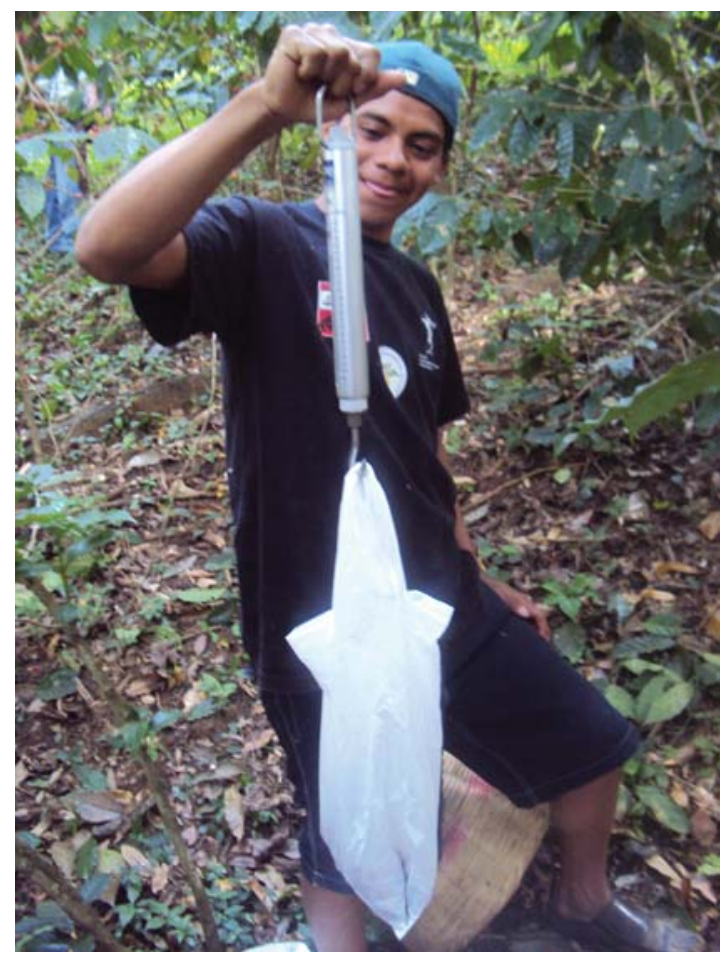

Figure 3.3. Weighing the harvested coffee. Photo by Evan Anderson 


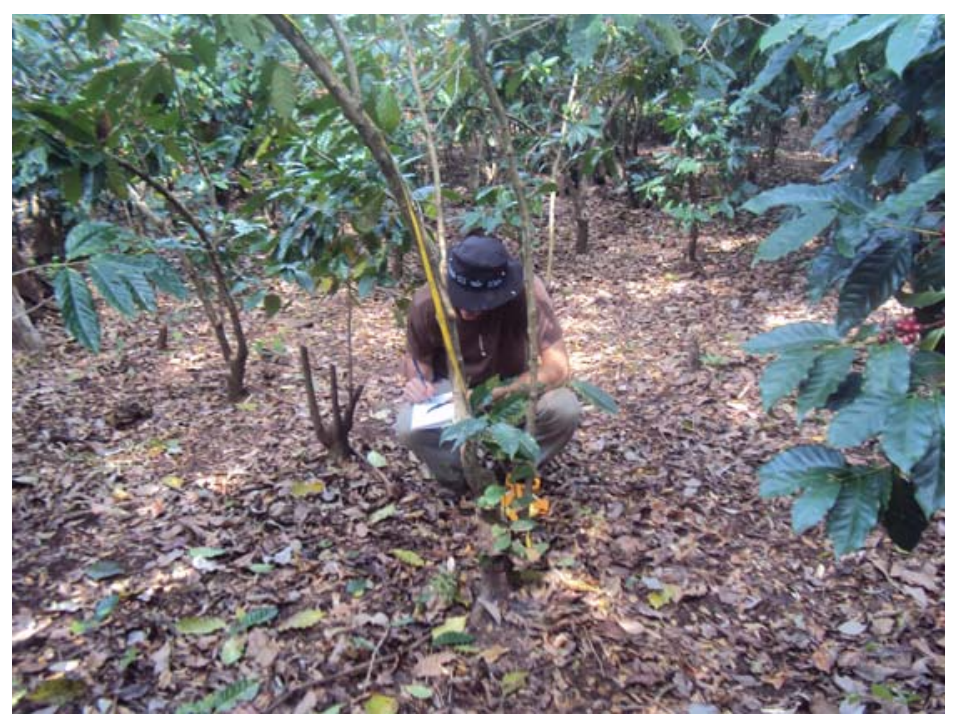

Figure 3.4. Recording coffee tree measurements. Photo by Steve Anderson

While the coffee was harvested, coffee tree diameter was taken at $35 \mathrm{~cm}$ from the ground using a standard D-tape and tree height was also measured with a Kenson fiberglass measuring tape (Tiger Supplies Inc. 27 Selvage St, Irvington NJ 07111) (Figure 3.4). There were instances when the coffee tree's stem split into multiple stems below the $35 \mathrm{~cm}$ mark; if this happened diameter was found by taking the square root of the sum of all stem diameters squared (USDA Forest Service 2007). Light measurements were also recorded next to each of the 4 coffee trees per plot using an EXTECH Wide Range Light Meter (Extech Instruments, Townsend West, Nashua, NH 03063 USA) to measure the amount of sun light passing through the overstory. Within the same farms on all plots, light measurements were taken at the same time of day. However, light measurements taken between farms were not taken at consistent times of the day. Calibration of the light meter was calculated by taking readings in full sunlight beginning at 7 am until $5 \mathrm{pm}$ at two hour intervals. These measurements were used to compare the differences between measurements taken in the farms and in full sunlight (Table 3.2). 
These steps were repeated in each of the 15 farms in each cover type plot. After all of the coffee for the study was harvested and weighed it was returned to the cooperative for processing.

Table 3.2.

Full sunlight calibrations (Kflux) and hour (7 am - 5 pm).

\begin{tabular}{cr} 
Kflux & Hour \\
\hline 18.00 & $7: 00 \mathrm{am}$ \\
25.00 & $9: 00 \mathrm{am}$ \\
40.00 & $11: 00 \mathrm{am}$ \\
40.00 & $1: 00 \mathrm{pm}$ \\
40.00 & $3: 00 \mathrm{pm}$ \\
18.00 & $5: 00 \mathrm{pm}$ \\
\hline
\end{tabular}




\subsection{Field Data Collection 2010}

For the 2010 picking season the field work was conducted in a slightly different manner. In the 2009 season, coffee trees were first marked with colored ribbon then once the harvest season began, they were picked. The main difficulty with marking the coffee trees first was that other community members would come through the farm before the harvest season and remove the colored tape leaving no sign of tree location. Therefore, during the first harvest season over half the plots within the farms had to be recreated. Subsequently, during the second harvest season, the plots were marked and harvested at the same time. The second season yielded more coffee and 30 farms were selected for the study. Out of the 30 farms, only two were not used from the first season because they had already been harvested.

Basal area measurements of balsamo and non balsamo cover types were taken in each of the 30 farms. Points were located using a systematic sampling design (Avery and Burkhart 1983) with a distance of 1.5 chains ( 1 chain $=66$ feet or 20.12 meters) between points. The caporal measured his pace by walking 1 chain alongside the measuring tape. Before basal area was measured, a rough sketch of the farm was drawn by the caporal to determine the direction of the transect. The caporal started at the corner boundary of a farm and paced 1.5 chains along the boundary, then using a Challenger A-1000 Sighting Compass (Suunto, Valimotie 7 FI-01510 Vantaa Finland), located the bearing of the transect and paced 1 chain. The first point of every transect was always paced 1 chain, the rest of the points along the transect were paced 1.5 chains. After pacing the required distance, a 5 foot wooden pole was inserted into the ground establishing the point at 
which basal area would be taken. Basal area was taken with a 20 basal area factor (BAF) prism (Avery and Burkhart 1983). The prism was held above the sampling point and used to view which trees would be measured at diameter at breast height (dbh). After the tree was measured, the tree was classified as either balsamo or non balsamo. This was performed at every point until arriving at the opposite boundary of the farm (Table 3.3).

Once arriving at the opposite boundary, the caporal would turn a 90 degree angle opposite the direction from which he started and pace 1.5 chains along the boundary. Upon arriving at the 1.5 chain mark, he would turn 90 degrees back towards the farm, set the compass to the opposite bearing (i.e. if first bearing was $60^{\circ} \mathrm{NW}$, the second going back the opposite direction would be $60^{\circ} \mathrm{SE}$ ) and pace the new transect 1 chain back into the farm. This was repeated until the entire farm was covered. 
Table 3.3.

Number of basal area points recorded in each farm.

\begin{tabular}{|c|c|}
\hline Farm number & Points \\
\hline 1 & 25 \\
\hline 2 & 13 \\
\hline 3 & 9 \\
\hline 4 & 7 \\
\hline 5 & 7 \\
\hline 6 & 9 \\
\hline 7 & 8 \\
\hline 8 & 10 \\
\hline 9 & 9 \\
\hline 10 & 10 \\
\hline 11 & 14 \\
\hline 12 & 10 \\
\hline 13 & 7 \\
\hline 14 & 9 \\
\hline 15 & 14 \\
\hline 16 & 10 \\
\hline 17 & 6 \\
\hline 18 & 7 \\
\hline 19 & 14 \\
\hline 20 & 11 \\
\hline 21 & 12 \\
\hline 22 & 8 \\
\hline 23 & 12 \\
\hline 24 & 7 \\
\hline 25 & 8 \\
\hline 26 & 18 \\
\hline 27 & 6 \\
\hline 28 & 14 \\
\hline 29 & 13 \\
\hline 30 & 5 \\
\hline
\end{tabular}




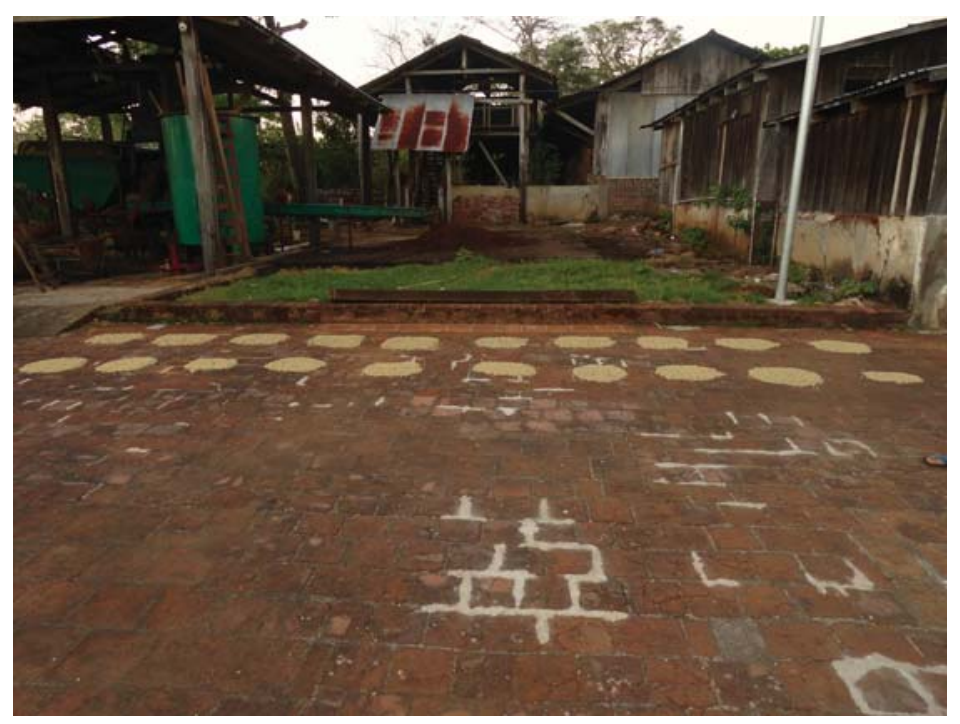

Figure 3.5. Coffee samples drying on patio. Photo by Evan Anderson

\subsection{Coffee Processing and Drying}

Market values on a community wide level were also calculated for coffee and balsamo. In order to calculate these values, the coffee had to be processed and dried. Twenty samples of coffee berries from throughout the cooperative were separated into $5 \mathrm{~kg}$ samples (Figure 3.5). These samples were each separately processed through a mechanized coffee pulper. After the pulp was removed, each sample was individually washed in a bucket with water to remove the remaining mucilage and excess pulp. The samples were then laid out separately to dry. The samples were left for 5 days to dry and during these 5 days, each sample was frequently turned over to be certain the entire bean was being dried. Once all the samples were dried, they were each individually weighed using the $20 \mathrm{~kg}$ scale. Afterwards, each sample was put separately in a nylon sack and beat on the patio floor to remove the parchment or remaining skin. They were removed from the bag, cleaned of the parchment, and weighed again. The recorded yield of the 
coffee harvested from each tree in the field was converted to dry coffee yield in $\mathrm{kg} /$ tree from the dry coffee samples. This was the final weight of the marketable bean.

Market values of balsamo were recorded as well. The director that oversees balsamo processing provided the weights and prices of balsamo resin from 2009 to 2011 . It should be noted that these prices and quantities are from what the cooperative sells to an intermediary outside buyer and not from community members.

\subsection{Interviews}

The study included structured interviews (Bernard 2002). The questionnaire is shown in appendix A. The questionnaire was developed from 18 months of participant observation and field experience. The questionnaire was approved by the Institutional Review Board at Michigan Technological University (M0804E).

Choosing informants was based on the purposive sampling method (Bernard 2002; Guest et al. 2006). This first section was specifically for members on the board of directors of the cooperative in the community. The second part to the questionnaire was more relevant for farmers.

Each of the interviews was given individually and in Spanish as to not intimidate or inhibit any answers from the interviewees. Notes were carefully taken from the interviews and if a question or answer was not understood, it was repeated until completely understood and answered. The majority of interviewees were men. The interviews also were conducted with the participants who were most active and experienced in balsamo/coffee work within the studied farms making answers more 
complete and thorough. After 15 informants were interviewed a saturation of information was reached and no new information was being provided (Guest et al. 2006).

Part of the interviews entailed the history of balsamo resin extraction and coffee management in El Balsamar. The interview was conducted with two key informants in the community that were able to recount the history from 100 years until the present.

Field observations of coffee and balsamo management, harvesting and processing are discussed in the study area background chapter.

\subsection{Data Analysis}

Data analysis was carried out using SAS (SAS Institute Inc., Cary N.C.) using the following procedures: PROC TTEST and PROC CORR (see Appendix B for SAS code used). Paired t-tests were used to determine differences between balsamo cover type and non balsamo cover type. Results from the paired t-test were declared significant at $\mathrm{P}<0.10$. $\mathrm{P}$ values are given throughout the results and discussion chapter. Correlations using Pearson's correlation test looked at correlations between cover type, coffee yield, diameter, height, light, and basal area. Correlations were declared significant at $\mathrm{P}<0.10$. 


\section{Chapter 4 - Study Area Background}

\subsection{El Balsamar}

El Balsamar is a rural canton (village) located in the department of Sonsonate in the municipality of Cuisnahuat. The community has 672 inhabitants and 162 families. The community has an elevation of $526 \mathrm{~m}$ a.s.1. The municipality of Cuisnahuat has a mean annual precipitation of $2,173 \mathrm{~mm}$ and a mean annual temperature of $24.3^{\circ} \mathrm{C}(\mathrm{SNET}$, 2006).

El Balsamar is made up of a cooperative (Asociacion Cooperativa El Balsamar) with at least one socio (cooperative member) per household. Through the cooperative socios can work to provide income for their households. Socios work for the cooperative extracting balsamo resin, harvesting coffee, cutting wood for construction and as night watchmen at the hacienda which is the cooperative's estate. Socios prefer balsamo resin extraction and coffee preparation and harvest because work is provided all year round. Socios also have individual farms on cooperative land where they can grow maize (Figure 4.1), sorghum (Figure 4.1), beans (Figure 4.2), and rice crops (Figure 4.3). 


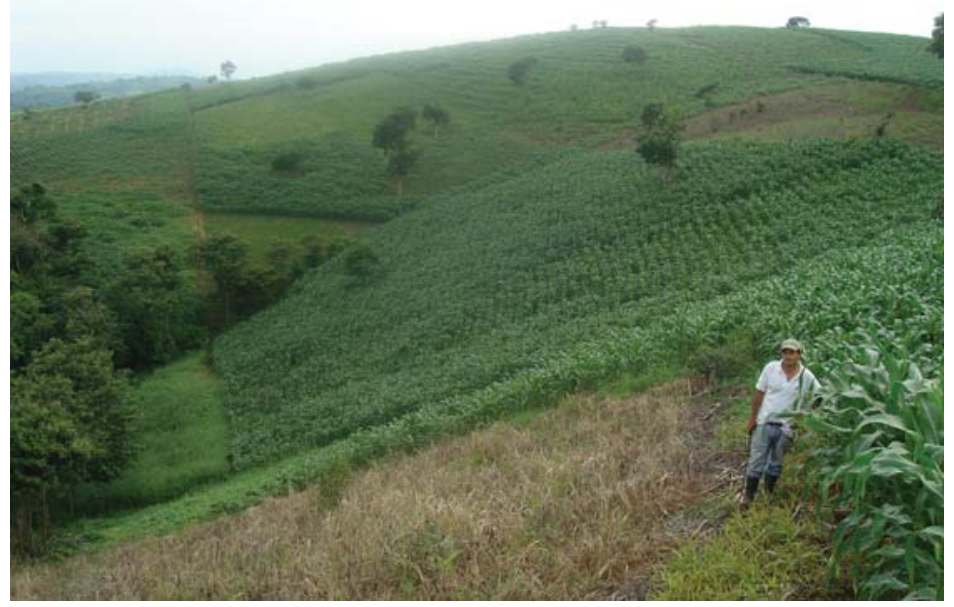

Figure 4.1. Farmer with maize and sorghum crops. Photo by Evan Anderson

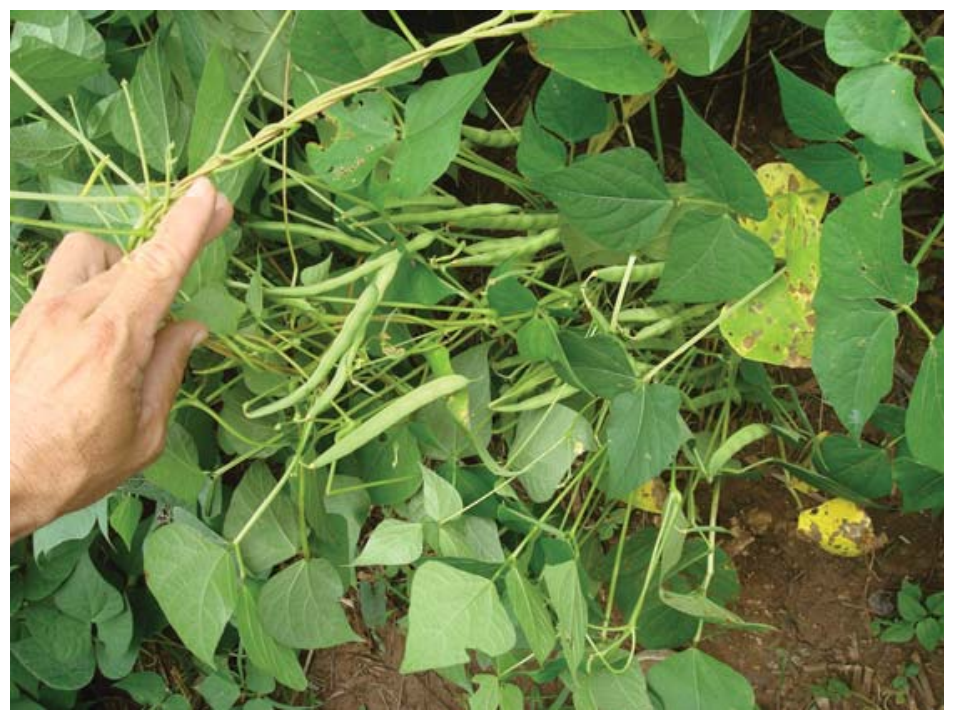

Figure 4.2. Bean crop. Photo by Evan Anderson 


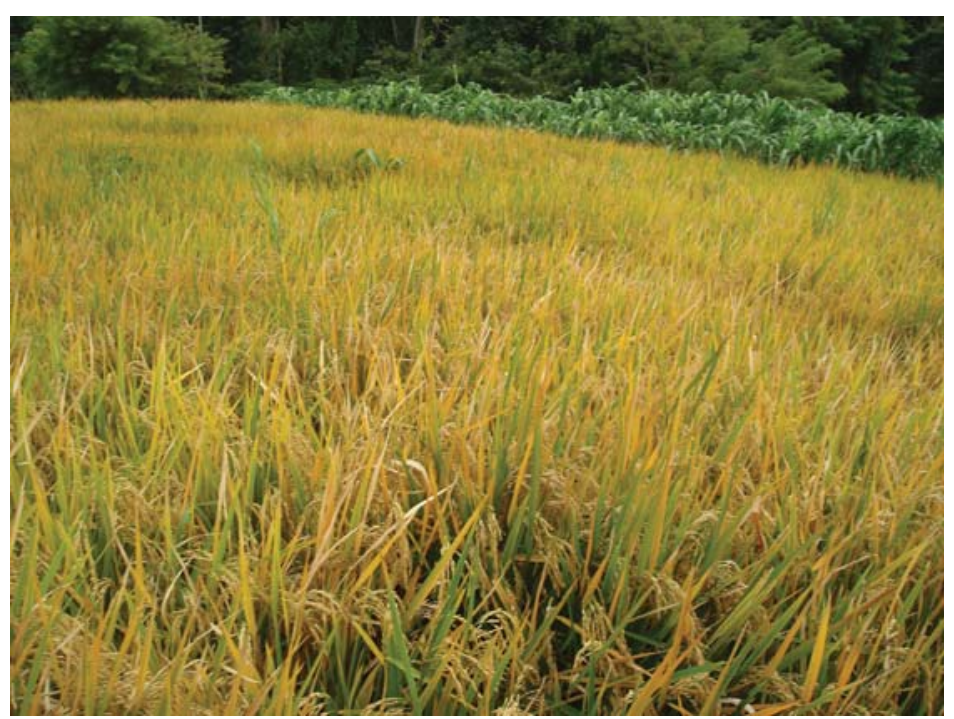

Figure 4.3. Rice crop. Photo by Evan Anderson

\subsection{The Cooperative in El Balsamar}

With few job opportunities in El Balsamar, community members rely on the cooperative for work. Preparing for coffee harvest season provides work in the community. Within the coffee farms, each socio is assigned one manzana (1 manzana $\sim 7,000 \mathrm{~m}^{2}$ ) to cut weeds (Figure 4.4). They do not receive payment for this service; it is an obligation as a socio. The cooperative does hire members to prune coffee trees. Socios work a rotation of one quincena (15 working days) and receive US\$5.00/day. Planting coffee trees offers additional income with socios working the same quincena rotation at US\$5.00/day. During the actual harvest season, socios are paid US $\$ 1.00 / 25 \mathrm{lbs}$ of coffee berries they harvest. Although the pay is low, socios are allowed to have family members help with the harvest and, if it is a high coffee yield year, some families can earn up to US\$20.00/day. 
The other primary source of work the cooperative provides to socios is balsamo tree resin extraction. Each socio is assigned their own balsamo tree plot to extract resin. Half the resin they extract and process is given to the cooperative while they keep the other half to sell in nearby towns. Nearby towns always pay the market price for balsamo resin. The market price for balsamo in 2010/2011 was between US\$5.50 - US\$6.00/lb. According to farmers, the market price for balsamo resin in 2010/2011 was more profitable than the 2009/2010 price of US\$2.50-\$2.75/lb.

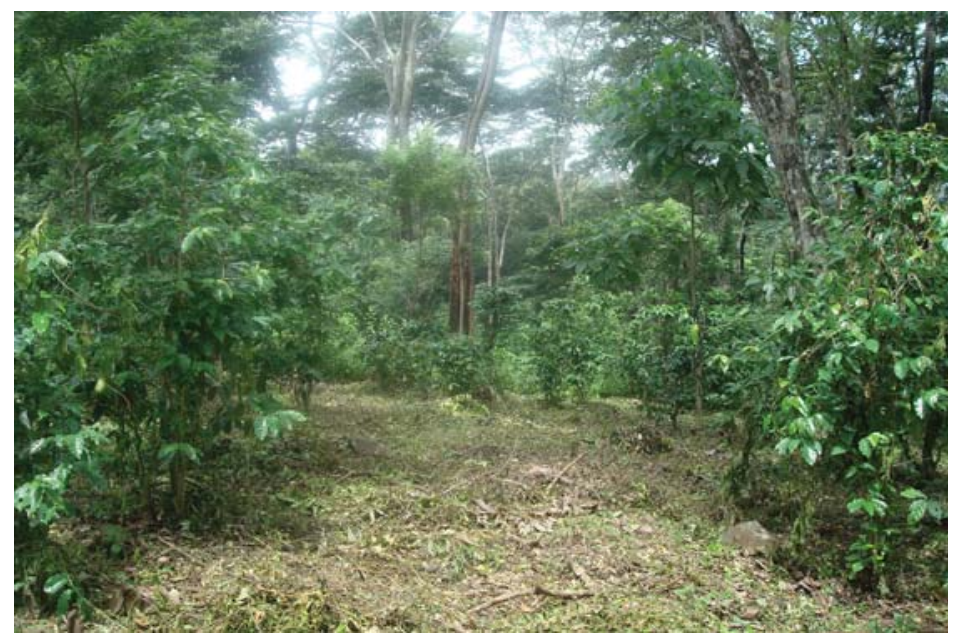

Figure 4.4. Coffee farm after the weeds have been cut. Photo by Evan Anderson 


\subsection{Land Tenure in El Balsamar}

On March 6, 1980 land tenure changed in El Balsamar. The agrarian reform was implemented and land was seized from large landowners and redistributed to laborers in the same community (Strasma 1983). According to community members in El Balsamar, the government seized 2,145 hectares from the previous landowner to be redistributed to community members and these community members formed the first cooperative in $\mathrm{El}$ Balsamar.

Since the agrarian reform in 1980, El Balsamar has been a cooperative community and still is to the present day. The land is equally divided among socios where all members have their own plot of land to plant their crops. Only 44 socios are beneficiaries of balsamo plots. Besides the beneficiaries, approximately 70 community mozos (paid assistants) help them with the balsamo resin extraction depending on the size of the beneficiaries' balsamo plot. In addition to the mozos, the beneficiaries' children, ranging between 16 and 25 years old, help their fathers with the balsamo resin extraction. The children receive no money from this as they are seen as extra labor in the household. When the market price of balsamo resin is low, the beneficiaries benefit from having children that assist them with the resin extraction. The balsamo plots that belong to the socios are located within the coffee farms, however socios are only allowed to harvest the balsamo resin from their trees.

Many other cooperatives in close proximity to El Balsamar have failed from unpaid debts. These cooperatives ultimately divided the land between community 
members where each member is responsible for his or her crops, coffee and balsamo trees.

The cooperative in El Balsamar has an unpaid debt from the early nineties and is at risk in having its land expropriated by the bank. As the president said, "We make just enough to pay the annual interest, but eventually, if we cannot pay the entire debt to the bank, the bank will seize land property and give it away to people who do not even live in the community."

\subsection{Balsamo (Myroxylon balsamum (L.) Harms)}

Balsamo (Myroxylon balsamum) is a tall tree that can reach heights up to 35 meters and the diameter of the trunk can reach almost one meter. Its leaflets are oddly pinnate, glabrous and bright green. The wood is aromatic and has a reddish color similar to mahogany. Although its wood is valued for flooring and furniture, its resin is of higher value (World Agroforestry Database 2009; Parker 2008). Balsamo grows in wet to dry lowland forests. It can grow in elevations up to 300 meters and can be planted in higher elevations (Parker 2008). Its distribution reaches from Mexico to Panama as well as Colombia and Venezuela (World Agroforestry Database 2009; Parker 2008).

The resin extracted from the balsamo tree is used industrially for its medicinal, cosmetic, aromatic perfumes, and gastronomical properties. The principal component found in the resin is cinnamein oil (World Agroforestry Database 2009; Parker 2008).

Many misconceptions about where the balsamo tree originated from are still present today. The most common name for balsamo is "Balsamo of Peru" (Parker 2008). 
When the Spanish colonized Latin America, balsamo arrived in Europe from Peru, which is where the misleading common name originates (Parker 2008). The Spanish shipped balsamo to Peru and changed the label to Balsamo of Peru to avoid theft by pirates. Balsamo resin was sought out by pirates for its medicinal properties. The name was a form of security and has been maintained until the present time (Canales 1984). The balsamo tree is native to the departments of Ahuachapán, Sonsonate and La Libertad in western El Salvador, which is also known as the Balsamo Mountain Range (Hector 1984).

\subsection{Management History of the Balsamo Tree in El Balsamar}

Extracting balsamo resin in El Balsamar has a long history. According to the eldest community members who are still living in El Balsamar, resin extraction and commercial use of balsamo resin started before the 1900s in the community. The interviews for this study provided a history of balsamo tree and coffee management in the community.

Before the agrarian reform was implemented, in the late 1800 s to early 1900 s the community of El Balsamar was owned by a Swiss landowner named Bravalio Sandoval. El Balsamar had over 500 hectares of land used for livestock, extracting balsamo resin, coffee and basic grains, all belonging to Sandoval. He was the owner of a nearby hospital and had two adopted Salvadoran children. Sandoval had a dispute with a doctor in his hospital and murdered him and later fled to the United States leaving his two adopted 
children as landowners in El Balsamar. Three of the four properties in El Balsamar were left to Sandoval's son, Carlos, and the fourth property to his daughter Blanca.

Carlos spent more time in the community than Blanca. He continued his father's work and hired laborers within the community to extract balsamo resin, tend livestock, harvest coffee, and manage the crop fields.

Extracting balsamo resin was the primary source of work in the community as it grew naturally and was in abundance. The areas where the balsamo tree grew were divided into cuadrillas (900 $\mathrm{m}^{2}$ plots). For each cuadrilla, Carlos assigned 14 laborers to extract balsamo resin.

The equipment farmers used to extract balsamo resin were a hachon (bundle of splintered pieces of wood that are burned at the tips) and pañales (old clothes used to absorb the balsamo resin). Carlos contracted outside labor to hammer wooden stakes into the balsamo trees for the laborers to climb and extract resin. Farmers feared using the stakes to climb because the stakes would sometimes break or rot causing the farmers to fall.

Carlos gave laborers nine pounds of clothes to use for absorbing the balsamo resin. Carlos did not realize that laborers were hiding the clothes and selling them, or wearing them for their own personal use. He came to realize this when the resin extraction production slowly decreased. Carlos halted balsamo resin production and left the community in search for outside work in the 1940s and did not return until six or seven years later. 
Carlos returned to the community in 1950 with a team to assist him in managing the community. He brought with him a property assistant manager, a clerk, a foreman to oversee the coffee farms, and a security crew.

Laborers were no longer assigned to work in cuadrillas, but were each assigned 200-300 balsamo trees for resin extraction. He still bought the laborers clothes to use for the resin absorption, but the security team was hired to prevent laborers from stealing the clothes.

Although extracting resin was still considered dangerous, during this time, the laborers used ladders to burn down lower on the trunk and ropes to help climb the wooden stakes. Once the resin was extracted and processed, the laborers would give 50\% of what they extracted to Carlos and he would purify his share and export it overseas while the labors sold their $50 \%$ in nearby towns and villages.

\subsection{Balsamo Resin Extraction}

Balsamo resin is extracted and processed between the months of October and July. From October until May or June, farmers extract the resin from the tree and from May until July they process the resin.

To begin the extraction process, the farmer first takes a bundle of splintered wood called a hachon, each piece approximately $30 \mathrm{~cm}$ in length. They tie the hachon together with a vine, make a fire and leave the hachon in the fire until the ends catch the flame (Figure 4.5). The hachon can be left smoldering and when blown on, it will catch fire again (Stratton, undated). 
To climb the balsamo tree, the farmer needs a plank to sit on while in the tree, rope to climb the balsamo tree, and a bag to carry the pañales (old clothes used to absorb the balsamo resin) to stick to the tree to absorb the resin. Some farmers choose to throw the rope around a nearby branch to pull themselves up and some prefer a ladder to extract resin lower on the tree. The majority of farmers climb with a rope.

Once the farmer is ready to burn, they tie themselves off by throwing the rope over a nearby branch or "v" slot and blow the hachon until it catches fire again. They place the tip of the flame against the bark until it starts to bubble (Figure 4.6). This does not harm the bark. If the farmers leaves the flame on the bark too long, the bark dries and no resin will leach out. Depending on the size and diameter of the tree, in a single day, a farmer can work between 10 and 23 balsamo trees.

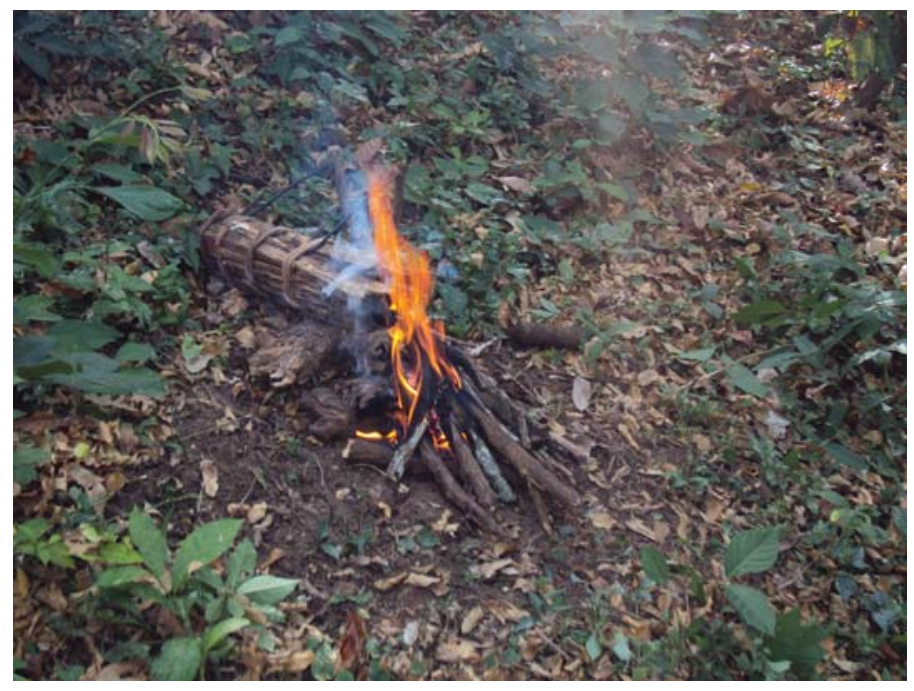

Figure 4.5. Hachon catching fire before used to burn balsamo tree. Photo by Evan Anderson 


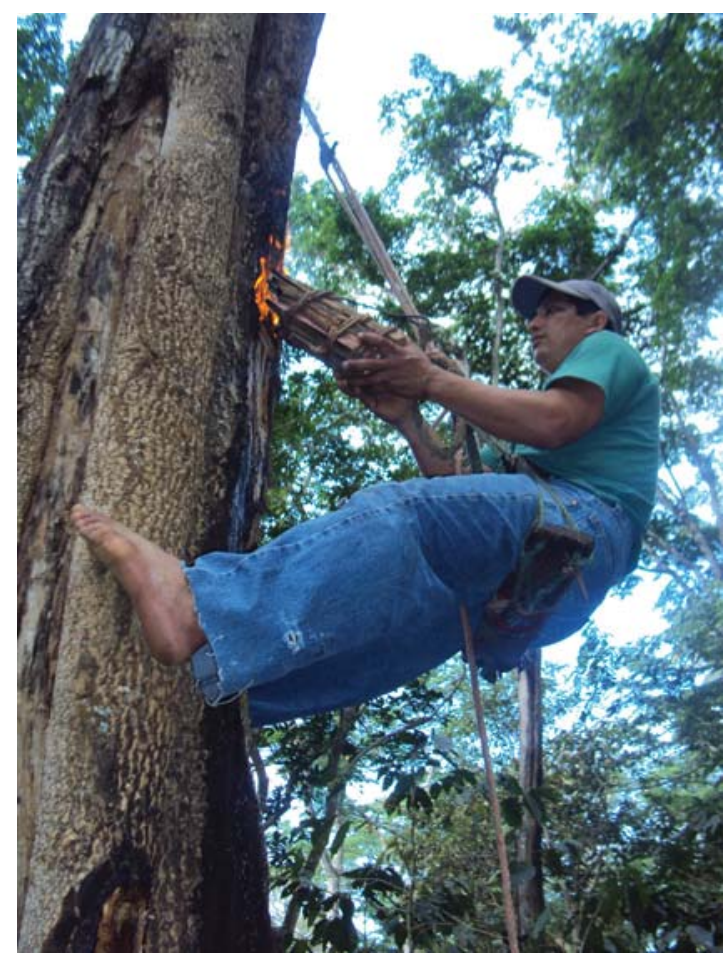

Figure 4.6. Farmer burning balsamo tree for resin extraction. Photo by Evan Anderson

Once the burn is complete, the farmers will return after 20 days when the bark is madurado (ripe) and will stick a pañal (pieces of old fabric) to the burnt part where the resin leaches out. They leave the pañal for 25 days, or until the pañal is saturated with balsamo resin. The farmers scrape the pañal off with a cuto raspador (a thick flat metal tool similar to a flat head screwdriver). In addition, the farmers scrape the burnt bark and put both the pañal and bark in a bag and take it to the balsamera (area where balsamo resin is separated from the pañales and bark). Eight days later, the farmers return to the same balsamo tree to stick another pañal to the exposed layer where the bark was scraped off. The pañal is left for another 25 days, or until the pañal is saturated with balsamo resin. This too is taken back to the balsamera (Stratton undated). 


\subsection{Processing Balsamo Resin}

The pañales and bark are processed in different ways. The pañales are processed by depositing them into a cistern of hot water and heating them for 40 minutes. After, they are taken and deposited into a metal cylinder with tiny holes around the sides. The farmers press the pañales into the cylinder using a heavy, blunt wooden rod.

Perpendicularly above the cylinder is a long steel rod used to twist the balsamo resin and water from the pañales. It is twisted with the pulling and pushing force of four farmers. The balsamo resin and water drain through the tiny holes in the cylinder into a large metal dish. The water is poured out of the dish and the balsamo resin remains in the dish because the resin weighs more than water. The pañales are placed on the floor, dried and reused (Stratton undated).

The bark is processed by first being placed through a wood chipper that produces finer bark shavings. These shavings are deposited into a large sack and the sack placed into another sack made from steel cable and nylon rope. Boiling water is poured into the sack and the sack is sewn shut as to not have any of the shavings exposed. The sack is then twisted from a device called a torcedera pushed by farmers (Figure 4.7). 


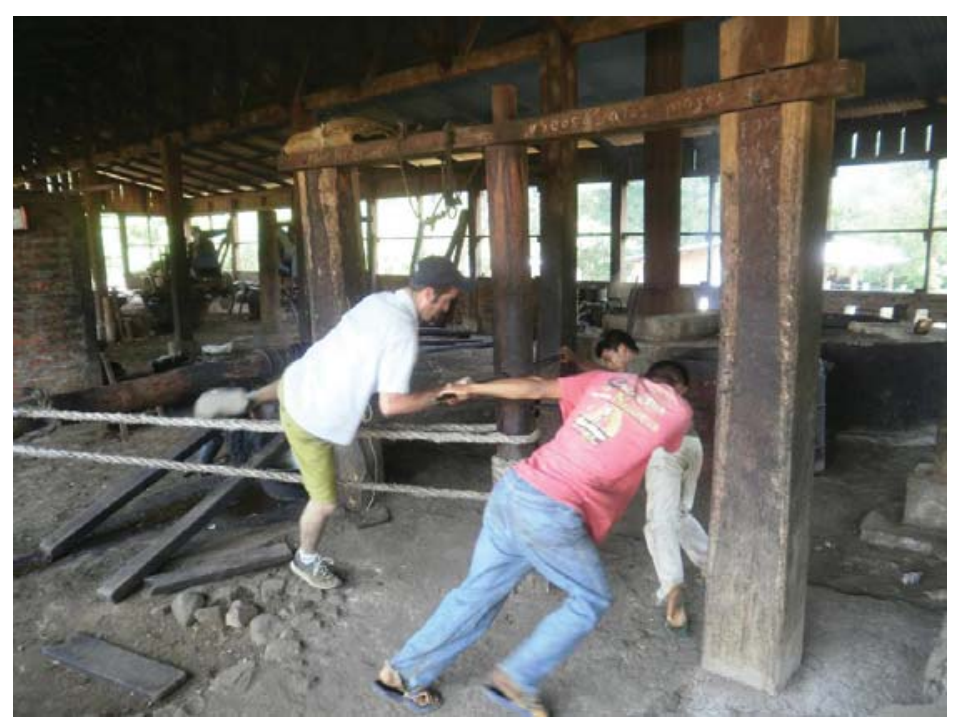

Figure 4.7. Twisting the sack of bark in the torcedera. Photo by Steven Anderson

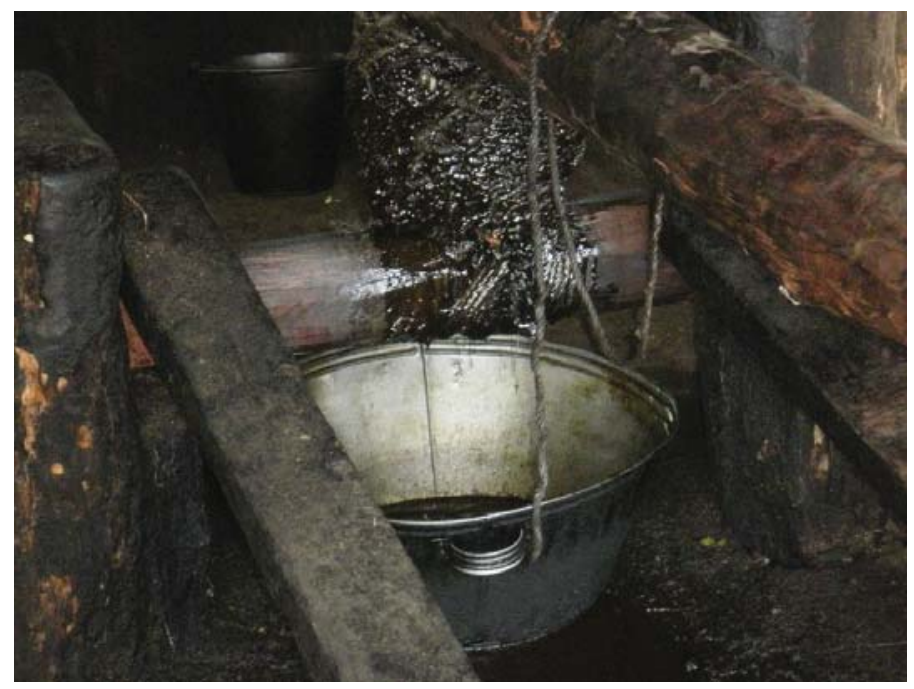

Figure 4.8. Balsamo resin from the bark shavings draining from a sack after being twisted in the torcedera. Photo by Evan Anderson

The balsamo resin is leached out from the shavings with the water into a large iron bucket (Figure 4.8). The balsamo resin is then separated from the water (Figure 4.9) (Stratton undated). The shavings are dried and later become estoraque (dried bark shavings used as incense to repel insects). 


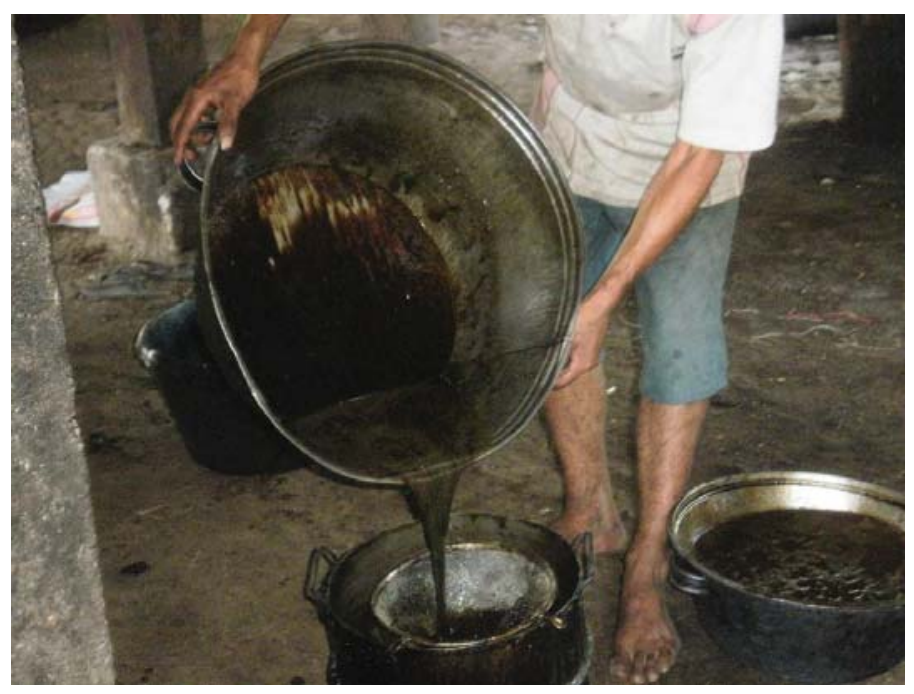

Figure 4.9. Separating the balsamo resin from water. Photo by Evan Anderson

\subsection{Coffee (Coffea arabica L.)}

The arabica coffee species originates from two varieties, var. typica and var. bourbon (Figure 4.10). Both originate from Ethiopia and have similar characteristics except the young leaves are bronze tipped and the fruit hanging from the branches loosely on the var. arabica while var. bourbon young leaves are green and the branches bearing fruit bend down at the tips (Wrigley 1988).

The var. bourbon arrived in El Salvador where it was widely cultivated and created other hybrid varieties (PROCAFE undated). One variety was the Tekisic or Salvadoran bourbon cultivar variety which is similar in in taste to the bourbon variety. The other variety was a mutation from the bourbon variety called pacas variety (PROCAFE undated). According to the cooperative in El Balsamar, the pacas variety yields more coffee than the bourbon. All trees in this study were the bourbon variety. 


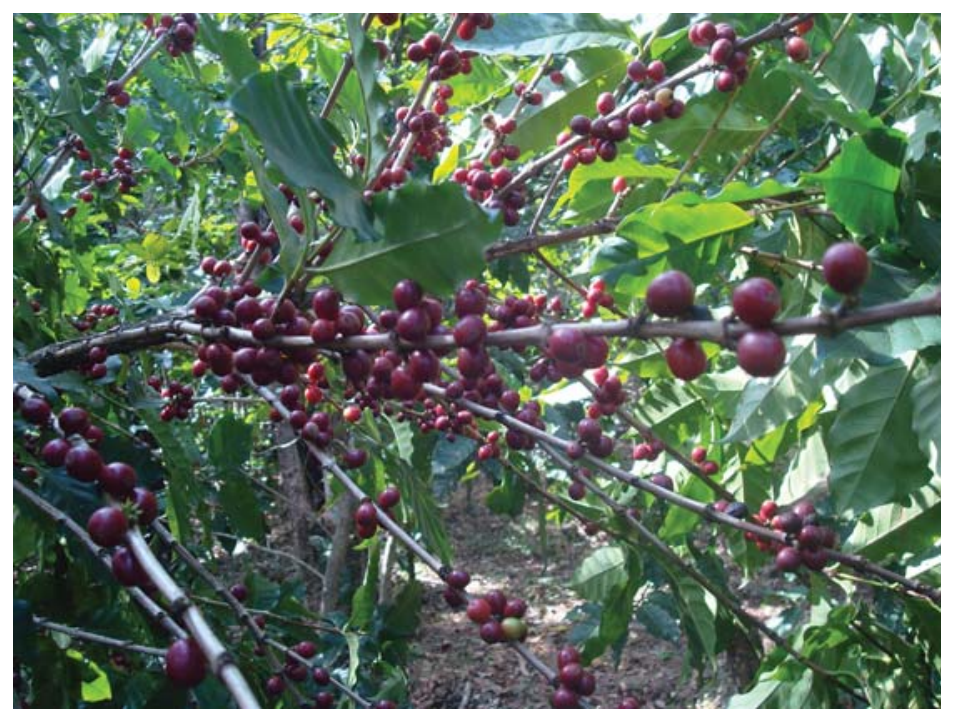

Figure 4.10. The bourbon variety in the coffee farms. Photo by Evan Anderson

\subsection{Management History of Coffee in El Balsamar}

Coffee was managed more meticulously in El Balsamar when Carlos Sandoval was the landowner than after the agrarian reform. During this time El Balsamar had more coffee farms than it does today, which provided more jobs not only for community members but for migrant workers as well.

Weeds were cut in the coffee farms twice a year by teenagers who did not attend school. Carlos hired approximately twelve teenagers and they would cut the weeds per cuadrilla. In addition to weeding, fallen balsamo seeds were gathered and planted in a nursery.

Community laborers applied fertilizer to the coffee trees. Today, community members apply fertilizer by walking parallel to the coffee row and throwing a small amount at the tree base. Prior to agrarian reform, each coffee tree was carefully fertilized 
by loosening the soil around the tree leaving a circular formation of loose soil. Then fertilizer was mixed with the loosened soil. When it rained, the water draining off the leaves from the coffee tree would drip down into the circular formation helping the fertilizer leach into the soil.

During coffee harvest season, the foreman who Carlos brought with him when he returned would assign thirty laborers to harvest each cuadrilla. The laborers had to be careful when harvesting coffee to avoid cutting branches and leaves from the coffee trees or they would be fined. After the harvest, only the higher quality coffee beans would be selected for export and the rest were sold within El Salvador. Carlos paid laborers 25 cents per $25 \mathrm{lbs}$ of coffee that was harvested. Although the payment was low, food was also provided daily to the laborers.

\subsection{Coffee Farms in El Balsamar}

Now the cooperative owns and manages the coffee farms in El Balsamar. Management practices include fertilizing coffee trees before and after flowering, pruning both coffee trees and non balsamo trees and cutting weeds once in the dry season and once in the rainy season. The cooperative plants two coffee tree types in the farms, the first and dominant variety is bourbon variety (Coffea arabica var. bourbon) and the second is a mutated variety of the bourbon called pacas. Varieties were not planted together. Trees were spaced approximately one meter apart. Only the bourbon variety was accounted for in the study since it is the most widely planted variety. 
In the 30 coffee farms sampled in the study, balsamo (Myroxylon balsamum) was a common overstory species. Table 4.1 presents non balsamo cover type species that were recorded in the 30 coffee farms sampled in the study.

Table 4.1

Non balsamo cover type trees recorded in the 30 farms sampled. Listed are the common name, genus and species.

\begin{tabular}{ll} 
Common name & Genus species \\
\hline Matapalo & Coussapoa purpusii Standl \\
Ojushte & Brosimum alicastrum SW \\
Volador & Terminalia oblonga Steud \\
Pepeto & Inga punctata Willd \\
Cincho & Quararibea funebris Vischer \\
Cedro & Cedrela salvadorensis Standl \\
Peine mico & Sloanea ampla I.M. Johnston \\
Copinol & Hymenaea courbaril L \\
Cole pava & Cupania guatemalensis Radlk. \\
Nispero & Manikara chicle Gilly \\
Mano de leon & Hampea stipitata Watson \\
Ronron & Astronium gravelolens Jacq. \\
Sisimite & Aphananthe monoica Hemsl. \\
Tempisque & Sideroxylon capiri Pittier \\
Cortez & Tavebuia donnell-smithii Rose \\
Jocote & Spondias purpurea L \\
Madre cacao & Gliricidia spium Kunth ex Walp. \\
Aguacate & Persea donnell-smithii Mex ex Donn. Sm. \\
Caoba & Swietenia humilis Zucc. \\
Laurel & Bourreria oxyphylla Standl \\
Guarumo & Cecropia obtusifolia Bertol \\
\hline
\end{tabular}




\subsection{Coffee Harvest in El Balsamar}

In general, the community in El Balsamar believes rainfall significantly affects coffee yield. According to community members, it must rain in March or April in order for the coffee tree to flower and once more after flowering. If it does not rain after flowering it can affect the yield as the rain helps wash away the withered flower, leaving the nodes to start budding (Wrigley 1988). One farmer interviewed said, "If it rains too early, the coffee ripens faster and the strong rains from the winter causes the coffee cherries to fall from the tree." On the Santa Ana volcano in Sonsonate, El Salvador, total annual rainfall does not have an effect on coffee production, but it is the rainfall in the first three months of the year that influence coffee production (Suarez 1960).

The coffee harvest in El Balsamar begins in late October and lasts until early January. Before the harvest, the president and treasurer of the cooperative visit each coffee farm to see how much coffee will be harvested. The amount of coffee in each farm gives them an idea of how many community members they can assign to the harvest.

The coffee harvest is worked in quincenas (15 working days). Every other Monday, community members arrive at the cooperative's hacienda to sign up for the coffee harvest. Once everyone has signed up, the president and treasurer of the cooperative call out the names of those that will be participating in the coffee harvest. Not all community members are able to participate in the harvest if coffee yield for that year is low and have to wait until the next quincena to sign up. If the president and treasurer determine that the coffee yield in each farm is high, every community member will be able to participate in the harvest. An example of this was observed in 2010, a 
good harvest year. Not only were all of the community members in El Balsamar able to harvest, but migratory workers from nearby villages came to harvest as well. Each person harvesting has their canasta (basket) and according to community members, one canasta of the harvested coffee berries is equal to one aroba $(25 \mathrm{lbs})$ and community members are paid US\$1.00/ 25 lbs (Figure 4.11).

At the end of the day, the coffee is taken to the hacienda and beans are separated. The ripened beans are weighed and given to the cooperative and the green beans can be kept by community members for personal consumption.

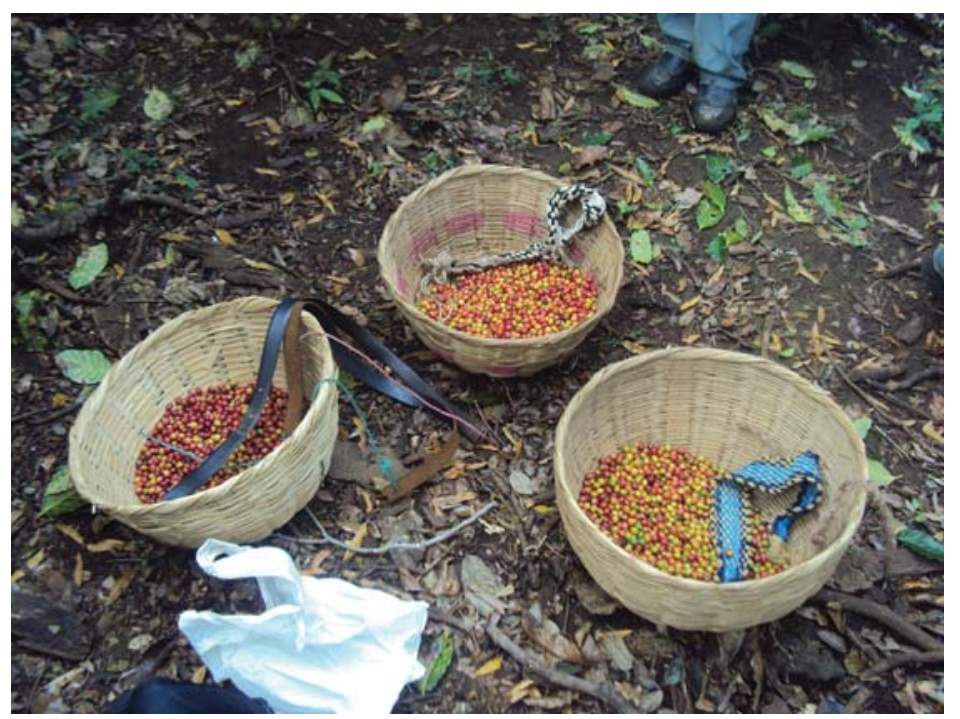

Figure 4.11. Canastas with coffee beans. One filled canasta is equal to $25 \mathrm{lbs}$. Photo by Evan Anderson 


\subsection{Processing the Coffee Bean}

After the ripened and green coffee beans are separated, the ripened beans are put into sacks and carried to the pulper. The ripened beans are poured into the pulper and the beans are separated from their epicarp (red skin) and mesocarp (pulp) (Wrigley 1988) (Figure 4.12). Water is pumped into the pulper by a gasoline motor. The water carries the epicarp and mesocarp through a channel to where it is emptied out onto the patio. The beans are carried by the water and emptied into a large concrete tank (Figure 4.13). The remaining beans with parchment are fed by water through a filter to separate the remaining pulp into a narrow concrete channel where they are cleaned of the remaining mucilage on the bean. After cleaning, the parchment is the only part remaining on the bean.

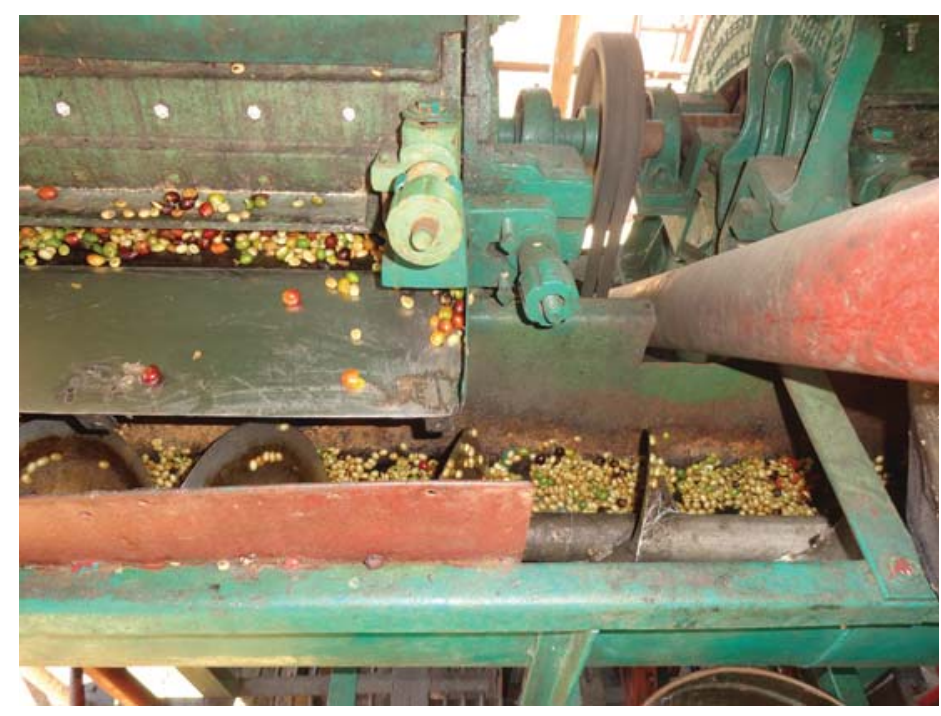

Figure 4.12. Separating coffee skin from the bean in the pulper. Photo by Evan Anderson 


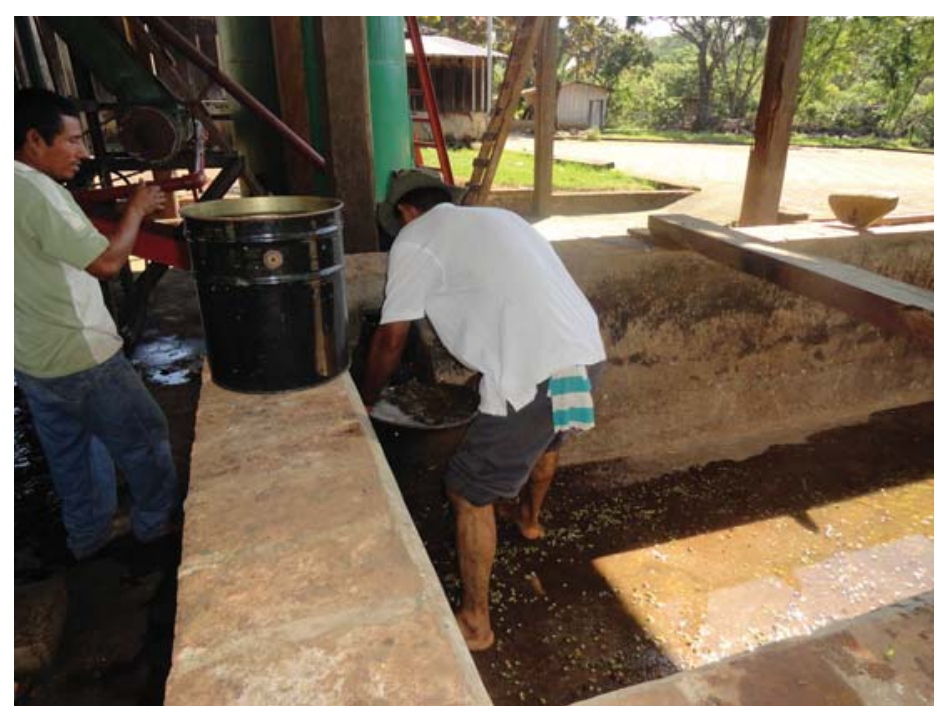

Figure 4.13. Coffee beans with parchment emptied into large concrete tank. Photo by Evan Anderson

The remaining bean with parchment is laid out on a patio to dry for 8-10 days. During the drying process, the coffee is repeatedly turned over by community workers, this helps accelerate the drying process (Figure 4.14).

After the coffee is dried, it is transported to an exporter for further processing (Figure 4.15). The exporter, Union de Exportadores, buys the beans from the cooperative and separates the parchment from the bean. 


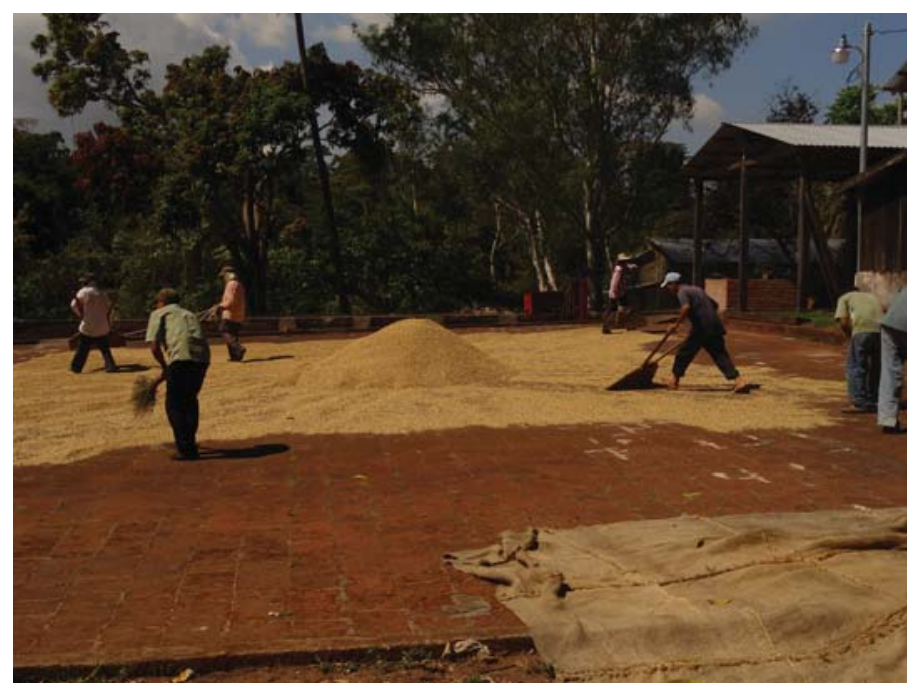

Figure 4.14. Coffee drying on the patio. Photo by Evan Anderson

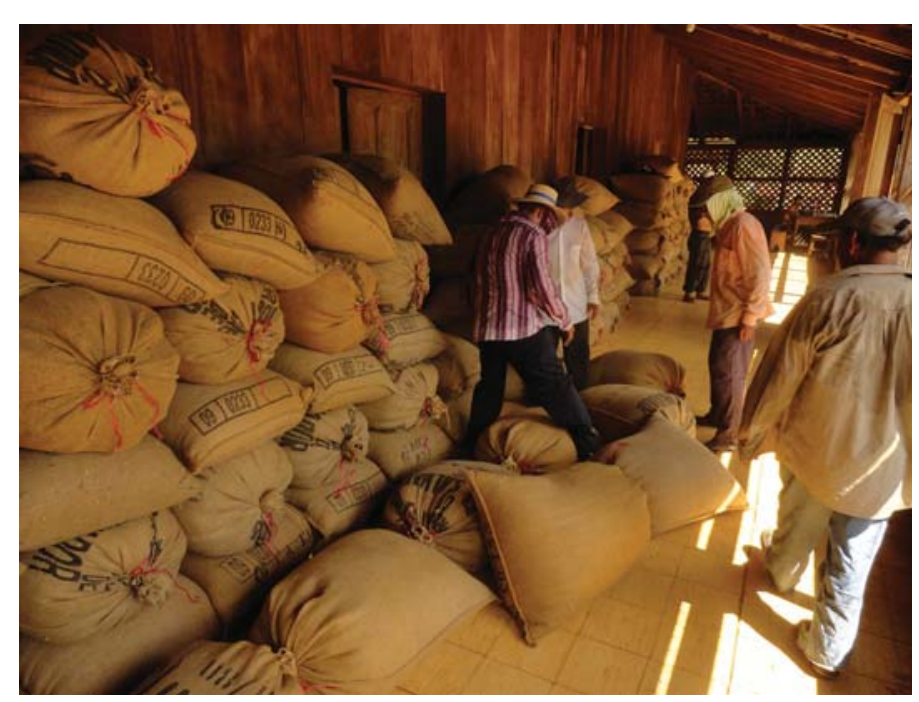

Figure 4.15. Coffee in sacks ready to be transported to exporter. Photo by Evan Anderson 


\section{Chapter 5 - Data}

This section presents the averages and standard deviations of the variables measured in balsamo and non balsamo cover type for years 2009 (Table 5.1), 2010 (Table 5.2) and both years (Table 5.3). The complete data set is shown in appendices C, D, E, and F.

Interviews were divided into two different sections. The first section was questions specifically for the board of directors of the cooperative and their knowledge of how the communities' coffee farms are managed, prices of coffee and balsamo resin, rainfall effect on coffee yield, and history of the balsamo tree and coffee in the community.

The second section was for farmers that worked in the coffee farms and harvested balsamo resin. These questions were divided more towards opinions on how balsamo cover type affected coffee yields, the effects balsamo resin and coffee prices had on households, other forms of income and their effects on households, management styles of coffee and the balsamo tree, and dates throughout the year community member's farmed coffee, balsamo and other crops. In general, farmers in the survey were between the ages of 25 and 45. All job titles of farmers were "farmers." Farmers were poor, generally only relying on balsamo resin, coffee and crops as a source of income. At times, some families had a family member who would migrate to larger cites for work. Each had a family household consisting of a husband, wife and 2-5 children. 
Table 5.1.

Mean and standard deviation of variables measured in balsamo and non balsamo cover types in year 2009. Standard deviations are in parenthesis. $(n=15)$

\begin{tabular}{lcc} 
& Balsamo & Non balsamo \\
\hline & & \\
$\begin{array}{l}\text { Coffee yield }(\mathrm{kg}) / \\
\text { tree dry weight }\end{array}$ & 0.10 & 0.11 \\
& $(0.04)$ & $(0.06)$ \\
$\begin{array}{l}\text { Diameter }(\mathrm{cm}) \\
\text { of coffee trees }\end{array}$ & 14.00 & 13.98 \\
& $(4.85)$ & $(4.27)$ \\
$\begin{array}{l}\text { Height }(\mathrm{m}) \text { of } \\
\text { coffee trees }\end{array}$ & 2.67 & 2.63 \\
& $(0.45)$ & $(0.44)$ \\
Light (kflux) & 9.62 & 3.98 \\
& $(16.58)$ & $(4.01)$ \\
Plot basal area & 23.31 & 19.98 \\
(m²/ha) & $(3.08)$ & $(5.17)$ \\
\hline
\end{tabular}


Table 5.2.

Mean and standard deviation of variables measured in balsamo and non balsamo cover types in year 2010. Standard deviations are in parenthesis. $(n=30)$

\begin{tabular}{lcc} 
& Balsamo & Non balsamo \\
\hline & & \\
$\begin{array}{l}\text { Coffee yield }(\mathrm{kg}) / \\
\text { tree dry weight }\end{array}$ & 0.17 & 0.20 \\
& $(0.08)$ & $(0.10)$ \\
$\begin{array}{l}\text { Diameter }(\mathrm{cm}) \\
\text { of coffee trees }\end{array}$ & 19.85 & 19.62 \\
& $(5.06)$ & $(4.49)$ \\
$\begin{array}{l}\text { Height }(\mathrm{m}) \text { of } \\
\text { coffee trees }\end{array}$ & 3.14 & 3.22 \\
& $(0.51)$ & $(0.53)$ \\
Light $(\mathrm{kflux})$ & 4.15 & 3.76 \\
& $(2.81)$ & $(2.88)$ \\
& & \\
$\begin{array}{l}\text { Plot basal area } \\
\text { (m²/ha) }\end{array}$ & 22.51 & 18.85 \\
& $(4.55)$ & $(4.8)$ \\
\hline
\end{tabular}


Table 5.3.

Mean and standard deviation of variables measured in balsamo and non balsamo cover types in both years. Standard deviations are in parenthesis. $(n=45)$

\begin{tabular}{lcc} 
& Balsamo & Non balsamo \\
\hline $\begin{array}{l}\text { Coffee yield }(\mathrm{kg}) / \\
\text { tree dry weight }\end{array}$ & 0.15 & 0.18 \\
& $(0.07)$ & $(0.10)$ \\
$\begin{array}{l}\text { Diameter }(\mathrm{cm}) \\
\text { of coffee trees }\end{array}$ & 18.08 & 17.91 \\
& $(5.64)$ & $(5.1)$ \\
$\begin{array}{l}\text { Height }(\mathrm{m}) \\
\text { of coffee trees }\end{array}$ & 3.0 & 3.05 \\
& $(0.53)$ & $(0.57)$ \\
Light $(\mathrm{kflux})$ & 5.81 & 3.82 \\
& $(9.51)$ & $(3.21)$ \\
$\begin{array}{l}\text { Plot basal area } \\
\text { (m²/ha) }\end{array}$ & $\begin{array}{l} \\
(4.14)\end{array}$ & 19.19 \\
& & $(4.88)$ \\
\hline
\end{tabular}




\section{Chapter 6 - Results and Discussion}

Farmers believe balsamo cover type decreases coffee yield when compared to non balsamo cover type species which, according to farmers, are better suited for higher coffee yields. This study was conducted through a series of statistical tests and interviews to test the validity of their beliefs. The first section of the chapter will describe what farmers' views are on coffee production under balsamo cover type as opposed to non balsamo cover type. The second and third sections will examine the evidence provided by t-tests (Snedecor and Cochran 1989) and Pearson correlation tests (Steel and Torrie 1960). These tests were used to help determine if a difference was present between coffee yields under the two cover types and to see which variables in the study correlated with each other. The fourth section discusses why farmers continue to plant coffee under balsamo cover type based upon the conducted interviews. The fifth section discusses the income effects on households from balsamo production, coffee production, other sources of community income, and the reliance community members have on the cooperative for this income. 


\subsection{Coffee Yield Under Balsamo and Non Balsamo Cover Types}

Farmers in El Balsamar have long been planting coffee trees under a variety of cover types, the dominant cover type being balsamo (Figure 6.1 and 6.2). Farmers believe the shade provided from the balsamo tree decreases coffee yield and coffee is better suited under other shade cover types. These beliefs are consistent with several other studies. Shade effects on coffee yield are of higher importance than basal area in Chiapas, Mexico (Pinto et al. 2000). An additional study stated that an increase in shade tree density will decrease coffee yield (Nolasco 1985). According to the results of the study in El Balsamar, basal area affected coffee yield.

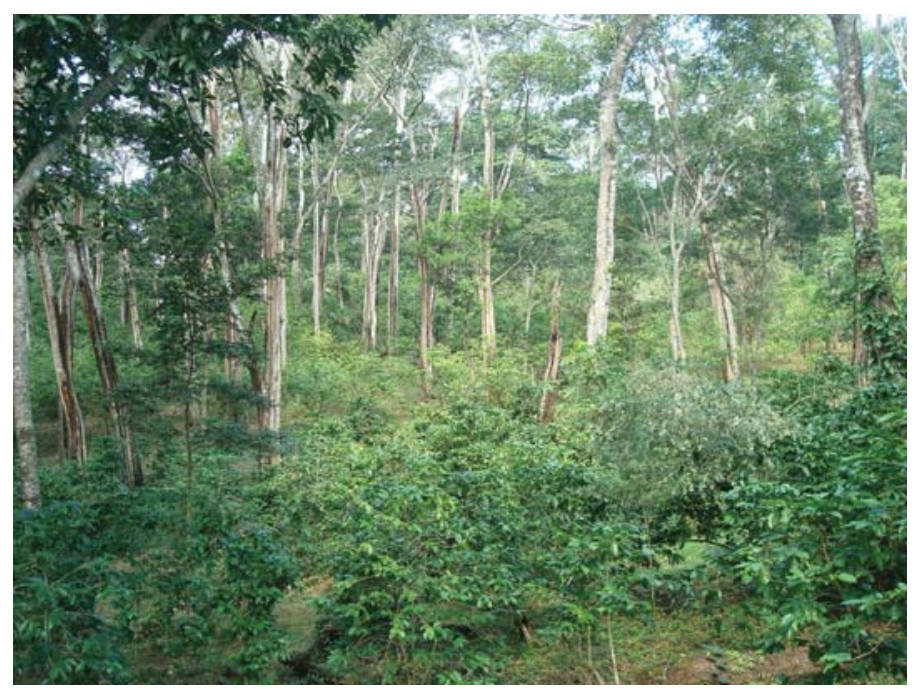

Figure 6.1. Coffee farm with balsamo tree as dominant overstory species. Photo by Evan Anderson 


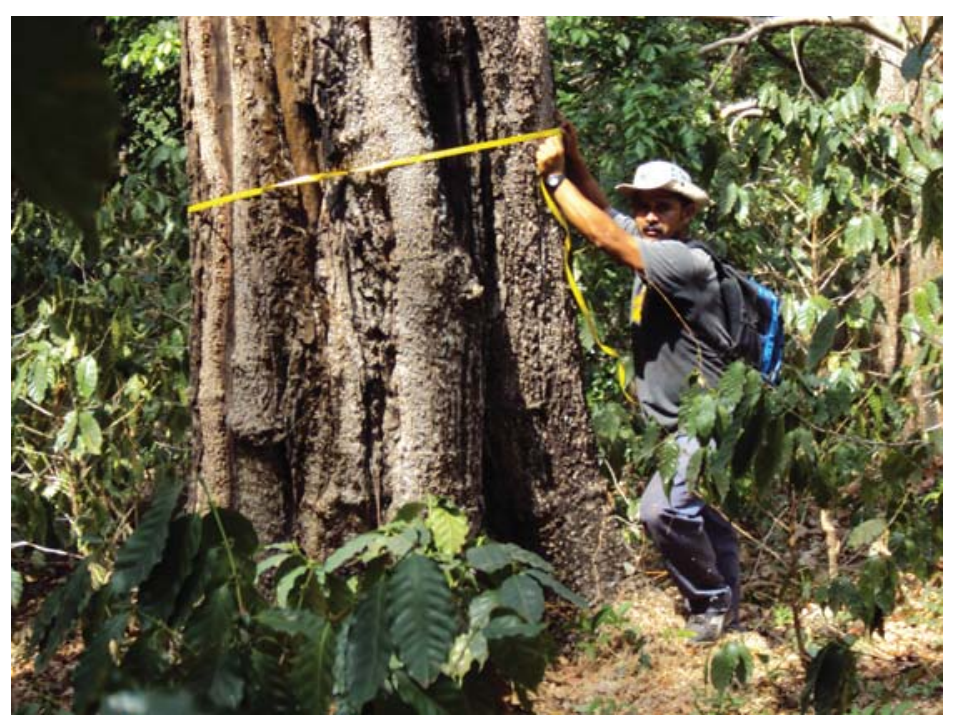

Figure 6.2. Large diameter balsamo tree.

Photo by Evan Anderson

The majority of farmers believe the balsamo tree retains much of the sun's heat, especially in the root system, as one farmer said, "the roots of the balsamo tree absorbs the heat from the sun and when planting coffee in close proximity to the tree, the heat kept in the roots reduces the production of coffee." Farmers say that balsamo is adapted to warmer climates and coffee is adapted to cooler climates.

In addition to the heat preserved by the roots, the balsamo tree's wide crown produces excessive shade which according to farmers, "reduces coffee yield." Farmers cannot prune back branches because according to them pruning will reduce the amount of resin that is produced by the tree and the resin is an important source of income for the community. Farmers also believe that any coffee farm with an abundance of balsamo trees, or high basal area, reduces coffee yield and ultimately the coffee farm will be lost if the farm is $100 \%$ balsamo tree because of the amount of heat the tree gives off. These statements highlight why farmers believe balsamo cover type reduces coffee yield. 
Statistical tests and structured interviews were carried out to test the validity of the statements made by the farmers.

\subsection{Differences in Coffee Yield Under Both Cover Types}

A paired t-test was used to determine if a difference was found between coffee yield under balsamo cover type and non balsamo cover type.

Using the paired t-test, statistically significant differences were found in coffee yield between balsamo cover type and non balsamo cover type. In 2010 balsamo cover type had a mean of $0.17 \mathrm{~kg} / \mathrm{tree}$ and non balsamo cover type had a mean of $0.20 \mathrm{~kg}$ $(P=0.071)$. In both years, balsamo cover type had a mean of $0.15 \mathrm{~kg} /$ tree and non balsamo cover type had a mean of $0.18 \mathrm{~kg} /$ tree $(\mathrm{P}=0.061)$. This difference, even though small, shows coffee yield is lower under the balsamo cover type. Year 2009 balsamo cover had a mean of $0.10 \mathrm{~kg} /$ tree and non balsamo cover type had a mean of $0.11 \mathrm{~kg} / \mathrm{tree}$. Yield in 2009 showed no difference $(\mathrm{P}=0.607)$ between the two cover types. According to farmers, "Not only was there less rain in 2009 , it did not rain at the right times, before and after the coffee flower bloomed." In 2009 the rainfall was $1951.4 \mathrm{~mm}$ causing the lower coffee yield while in contrast, rainfall in 2010 was $2719.2 \mathrm{~mm}$ (Table 6.1). 
Table 6.1.

Monthly rain data (mm) for 2009 and 2010 within a $17 \mathrm{~km}$ radius of El Balsamar.

\begin{tabular}{lcc} 
& 2009 & 2010 \\
\hline January & 0.0 & 0.0 \\
February & 0.4 & 0.9 \\
March & 0.2 & 0.1 \\
April & 29.7 & 66.5 \\
May & 272.3 & 570.0 \\
June & 241.3 & 588.0 \\
July & 152.8 & 426.0 \\
August & 449.3 & 304.0 \\
September & 376.0 & 788.5 \\
October & 201.0 & 25.0 \\
November & 258.7 & 17.5 \\
December & 0.0 & 0.0 \\
\hline
\end{tabular}

\subsection{Environmental Variables Within Coffee Farms}

Pearson's correlation test was used to determine which variables (cover type, coffee yield, coffee tree diameter and height, light, and cover type basal area) might be correlated with the lower coffee yield under balsamo cover type. Although farmers blame the low coffee yield in 2009 on low rainfall, basal area could have affected the low yield as well. In 2009, basal area had a negative correlation with coffee yield $(r=-0.21$, $\mathrm{p}=0.03)$. As basal area decreased, coffee yield increased. Basal area was also correlated with cover type $(\mathrm{r}=0.38, \mathrm{p}=<0.0001)$. As basal area increased, it was more likely that 
the cover type was balsamo. In summary, the farmers were correct in stating that coffee farms with higher basal area had lower coffee yields and balsamo cover type plots had lower coffee yield.

Correlations in 2010 showed coffee yield was negatively correlated with cover type $(r=-0.14, p=0.03)$. As coffee yield decreased, it was more likely that the cover type was balsamo. This supports farmers statements that coffee yield is greater in non balsamo cover types. Coffee yield was also negatively correlated with basal area $(r=-0.24, p=0.0001)$. Similar to 2009, 2010 data supports farmers' statements, plots with a higher basal area of balsamo cover type had lower coffee yields. Coffee yield was correlated with height $(\mathrm{r}=0.29, \mathrm{p}=<0.0001)$ and diameter $(\mathrm{r}=0.14, \mathrm{p}=0.03)$ of the coffee tree. As height increased, coffee yield increased and as diameter increased, coffee yield increased. No significant correlation was found with light and coffee yield $(\mathrm{r}=0.06$, $\mathrm{p}=0.32)$ in 2010 .

The only new information when both years were analyzed was the positive correlation between year and coffee yield $(r=0.32, p=<0.0001)$. It was likely 2010 had a higher coffee yield than 2009. This would support farmers' statements that 2009 had a lower coffee yield than 2010 .

Similar to 2010, coffee yield correlated with height $(\mathrm{r}=0.28, \mathrm{p}=<0.0001)$ and diameter $(r=0.14, p=0.03)$ in both years. As height of the coffee plant increased, coffee yield increased and as diameter increased, coffee yield increased. Unmeasured environmental factors within the farms could also have influenced coffee yields in 2009 , 2010 and both years. 
Farmers mentioned that light had an effect on coffee yield. Using paired plots, light was measured in balsamo and non balsamo plots and no significant difference in light intensity was found in 2009,2010 or data from both years combined $(2009 \mathrm{P}=0.27$; $2010 \mathrm{P}=0.58$; both years $\mathrm{P}=0.21$ ).

\subsection{Continued Coffee Farming Under Balsamo Cover Type}

Farmers are correct in their belief that coffee yield is lower under balsamo cover type. However, they still continue to plant coffee under balsamo cover type. Answers given by farmers in the structured interviews revealed why they continue this type of management.

The mean basal area of balsamo trees in the thirty farms measured was $98.4 \mathrm{~m}^{2} / \mathrm{ha}$ with a standard deviation of 19.8 and the basal area of non balsamo trees was $82.1 \mathrm{~m}^{2} / \mathrm{ha}$ with a standard deviation of 20.92. Balsamo plots have a higher basal area than non balsamo trees. The balsamo tree is known as a shade tree for coffee in El Salvador (World Agroforestry Database 2009). Although farmers know coffee yield is lower under balsamo cover type, they continue to plant coffee under balsamo cover type.

One hundred percent of farmers interviewed believed if all balsamo trees were replaced by non balsamo cover type species the result would be higher increases in coffee yield. They refuse to carry this out because like coffee, balsamo is a source of income for the community. Out of the 15 farmers that were interviewed $100 \%$ believe income gained from balsamo resin compensates for what is lost in income from a low coffee yield. According to one farmer, "if coffee yield is low because of low rainfall one year, the 
resin extracted from the balsamo tree for that year compensates for the loss in coffee income." Two studies conducted in Turrialba, Costa Rica suggests that shade trees are used as insurance to compensate income loss from tea (Camellia sinensis L. Kuntze), cacao (Theobroma cacao L.), coffee (Coffea spp. L.), and other perennial crops (Beer 1987; Beer et al. 1998). An additional study in the Ivory Coast concluded that farmers who intercrop coffee and cocoa with multipurpose shade trees are willing to accept the loss in coffee and cocoa yield for benefits such as medicine and fruits the shade tree provide them (Herzog 1994). The balsamo tree and the coffee tree are viewed as two sources of income for the farmers. Other studies show that multi cropping maximizes the returns farmers receive from the crops (Altieri 2000; Dorset 2008; Godoy and Bennet 1989; Thrupp 1998).

Table 6.2 presents international coffee prices in dollars in El Salvador per 101.2 lbs of coffee from November to January 2009/2010 and 2010/2011. Mean coffee prices for 2009/2010 and 2010/2011 are also presented. Prices from the Coffee Beneficiaries and Exporters Association confirm what the cooperative earned from these harvest seasons. Farmers want to guard against risky price fluctuations.

\section{Table 6.2.}

Mean coffee prices in El Salvador for 2009 - 2011.

\begin{tabular}{lll} 
November & 90.30 & 148.10 \\
December & 96.50 & 156.90 \\
January & 93.10 & 174.10 \\
Mean & 93.30 & 159.70 \\
\hline
\end{tabular}




\subsection{Income Effects on Farmers' Households}

This section first discusses how the income of balsamo resin, coffee and other sources of income are distributed throughout the community. The second part discusses how these incomes affect the farmers and their households. The third part discusses the advantages and disadvantages to balsamo tree management and coffee management.

The mean market price for dry coffee/101.2 lbs in 2009 was lower with a mean of US $\$ 93.30$ when compared to the price in 2010 with a mean market price of US\$159.70. The 2009 coffee harvest season earned the cooperative US\$12,129 and 2010 earned them US\$105,354.

The cooperative pays US\$1.00 for every aroba (25 lbs) of coffee berries harvested. In 2009, 107,879 lbs of coffee berries were harvested by the farmers resulting in US $\$ 4,315$ dispersed among those who harvested. In 2010, 547,445 lbs of coffee berries were harvested by the farmers resulting in US\$21,897 dispersed among those who harvested. It was likely since 2009 yielded less coffee that fewer households participated in the harvest whereas in 2010 all 162 households in the community participated in the harvest earning each household approximately US\$135.

Market prices fluctuate annually for coffee. Figure 6.3 illustrates the average annual price volatility averages of Other Mild Arabica Coffee. Coffee from El Salvador is included in this category. 


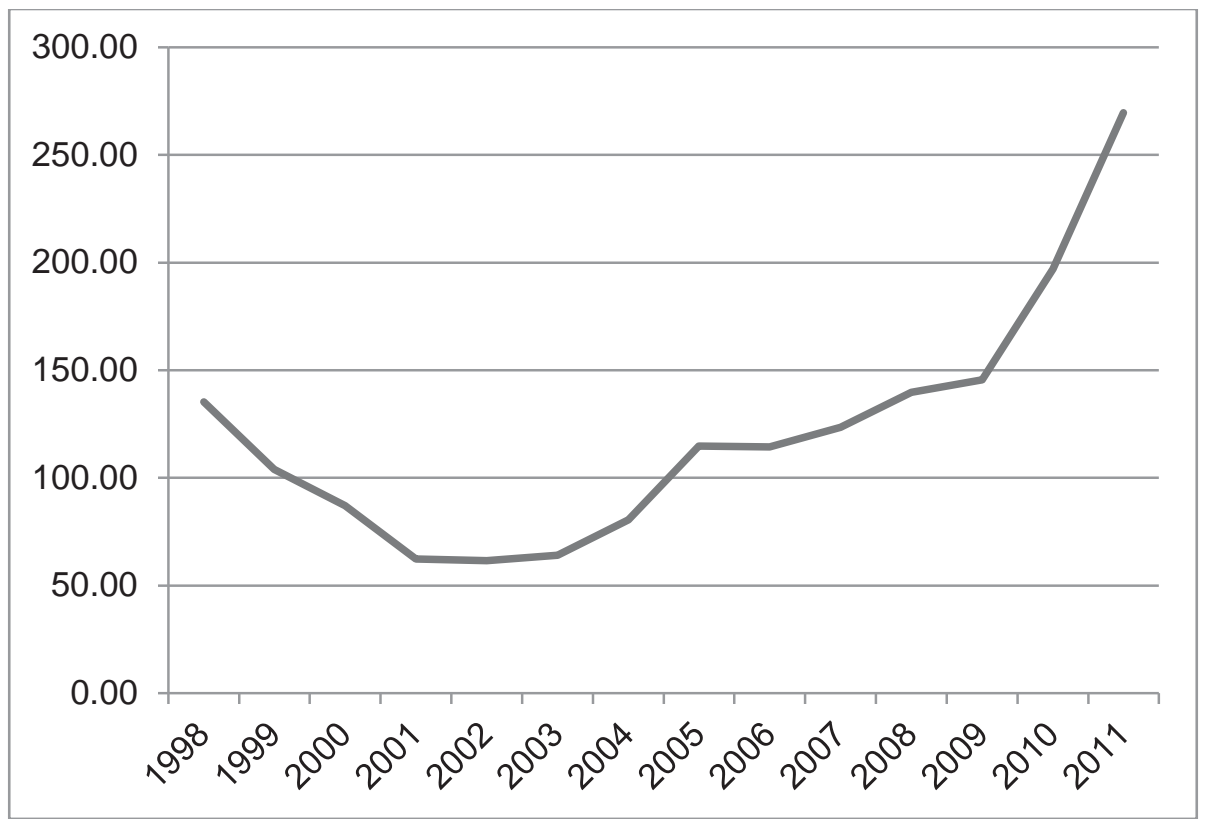

Figure 6.3. Average annual coffee prices (US cents/lb) from 1998 to 2011 (Data source: International Coffee Organization 2012)

In addition, the 2009/2010 balsamo resin season market price was low, averaging between US $\$ 2.50 / 1 b$ to US $\$ 2.75 / 1$ b compared to the price in $2010 / 2011$ between US $\$ 5.50 / \mathrm{lb}$ to US $\$ 6.00 / \mathrm{lb}$. The $2009 / 2010$ balsamo resin harvest earned the cooperative between US\$2,177 - US\$2,395 and 2010 earned them between US\$27,676 - US\$30,192.

The farmers keep approximately half of the balsamo resin they harvest and give the other half to the cooperative. In 2009/2010, the 44 farmers of the balsamo plots earned between US\$2,177 - US\$2,395 with each farmer generating approximately US\$50 in income from extracted balsamo resin that season. Since the amount was low, the farmers were unable to hire mozos (paid assistants) for the 2009/2010 season and relied more on their sons to help them with the resin extraction. This was considered a low income year by $100 \%$ of the farmers interviewed. Generally if the market price of balsamo resin is low, fewer farmers extract balsamo resin. This leads farmers and their families to search for other sources of income. In 2010/2011, farmers earned between 
US\$27,676 - US\$30,192 with each farmer generating US\$660 in income. This was considered a high income year for balsamo resin extraction and farmers were able to hire community mozos to help them harvest. Mozos may work anywhere between 15 - 30 days in a balsamo harvest season earning them between US\$75 - US\$150. Mozos who extract balsamo resin are also able to keep a portion of the resin they extract for themselves to sell, earning themselves extra income.

Approximately $20 \%$ of the farmers interviewed sent their wives to the capital San Salvador to work as domestic housemaids. Depending on the patron (owner of the house), women can earn between US\$100 and US\$140/quincena (15 working days). In the community women rely on the men for income; if a woman does work, the most she would earn in a day would be US\$5. Although women migrating to the city would earn more than working in the community, they have additional expenses such as transportation, food and sometimes lodging.

One hundred percent of the women that work outside of the community return every two weeks to bring the money that they earned to the household. Some women stay for the weekend, then Monday morning return to work. Other women returned to El Balsamar every day to every seven days. These women were more likely spending less on board and food, but more on transportation to and from the community.

Farmers are less likely to migrate to the city for work, staying in the community to tend to their crops. Approximately $6 \%$ of the farmers interviewed left the community in search of outside work. One farmer recounts that, "In the city we are barely paid minimum wage and it is almost not worth it because of the extra costs in the city and the 
dangers associated with city life, but sometimes there is no choice, if we do not search for work, our family does not eat."

After the harvest, crops are dried and stored, used for consumption and at times, portions of the harvest are sold for household needs such as staple foods, clothes, medicine, community laborers, or transportation to the hospital.

Table 6.3.

Mean basic grain prices (US\$/quintal) in El Salvador in 2009 and 2010. Standard deviations in parenthesis. Data source: Ministry of Agriculture El Salvador.

\begin{tabular}{lcc} 
& 2009 & 2010 \\
\hline Bean & 48.79 & 64.80 \\
& $(6.52)$ & $(27.61)$ \\
Maize & 15.04 & 14.27 \\
& $(1.21)$ & $(1.42)$ \\
Rice & 50.47 & 37.88 \\
& $(4.91)$ & $(2.33)$ \\
\multirow{2}{*}{ Sorghum } & 16.29 & 12.63 \\
& $(0.57)$ & $(1.49)$ \\
\hline
\end{tabular}


Eighty percent of the farmers interviewed used the money earned from crop harvest to pay off debts. Table 6.3 presents prices of maize, beans and sorghum in 2009 and 2010.

Before planting season, farmers take out loans to buy fertilizers and pesticides they need for their fields. The loan company FUSALD lends money specifically to farmers for their crop needs. Each farmer can take out a maximum loan of US\$300 with an annual interest of $25 \%$. If the farmers have a productive harvest season, the loan can be paid off within the year. Drought, plagues and torrential rains can cause production to be low. Sixty percent of the farmers interviewed were in debt. When the balsamo resin and coffee harvests years are unproductive, households and families are forced to search elsewhere for work.

Harvesting balsamo resin and coffee both have advantages and disadvantages in terms of skill, financial requirements and what the cooperative and farmers earn from each crop. More inputs are used when managing coffee farms. The community cooperative pays community members to fertilize, prune, and cut away ground cover vegetation in the coffee farms. In addition to this, the cooperative purchases the inputs used in managing the coffee farms. To manage balsamo trees, inputs are utilized, but the cost of the inputs is minimal. In addition, money earned from balsamo resin sales is used to purchase inputs to manage coffee farms. Although coffee is more expensive to manage, it is more dangerous to extract balsamo resin.

Risks of falling from a balsamo tree or incinerating a coffee farm are risks the farmers face. As one farmer mentioned in an interview, "there is a communication between you and the tree, but sometimes that communication is broken and you fall. It is 
very dangerous, but when work is scarce in the community you are forced to climb." A certain skill level is involved when harvesting balsamo resin. Farmers have to be adept at tree climbing, knot tying, resin tapping, timing of resin absorption, and processing the extracted resin.

Farmers realize this type of work is dangerous, but they have been working this way for so long it is ingrained into their culture and heritage as one farmer mentioned, "Balsamo resin has been extracted in the community for at least 100 years, maybe longer. It's in our blood and culture to continue the work that our great great grandfathers started." With coffee a lower skill level is involved, the farmer simply walks to a tree and picks the ripened cherries. What is important with coffee harvesting is the speed at which coffee trees are harvested. The faster the harvest, the more money a farmer will earn.

A great divide separates the amount of money and type of work that is devoted in managing coffee and balsamo trees. For a normal coffee harvest season where all coffee farms contain coffee, households may earn between US\$100 - US\$150. It should be noted that what the household earns from harvesting coffee is based on the coffee yield for that year. Pruning and fertilizing coffee trees for two quincenas could earn the household an extra US\$150 resulting in US\$250 - US\$300.

A single farmer can earn between $\$$ US50 - US\$680 in a season extracting balsamo resin depending on the market price. These prices are based on what the single farmer can earn. Prices may vary depending on how many family members are involved with harvesting balsamo resin and coffee. All of the money earned harvesting coffee is kept by the farmer and his family. Farmers are more likely to pay mozos to help them 
harvest and process the resin, therefore not all of the money earned is kept by the farmers. Farmers see both as sources of income that support their families.

The community views both balsamo resin and coffee as sources of income. Both are valued in terms of who in the community can benefit from their products. Over half of the households in the community benefit from income earned by balsamo resin. All households are more likely to earn income from a coffee harvest. Farmers may earn more from balsamo resin, but not every household benefits.

Prices vary from farmer to farmer and prices fluctuate according to the market. All of these factors affect the farmer and their household. The farmers of El Balsamar have four sources of income. The two main sources are balsamo resin and coffee, each provided by the cooperative. The other two sources are crops and migratory work. These latter two sources of income vary in their importance to the farmer and his household depending on market prices of balsamo and coffee yield.

What farmers earn from balsamo resin and coffee are enough to take care of their household and family and little more. Occasionally, farmers will spend money on transportation to go on community excursions such as soccer matches or church retreats to the beach. Farmers that harvest coffee and balsamo resin in El Balsamar generally do not receive any remittances from family members working outside of El Salvador. Families that do receive remittances, approximately ten households out of 162 families, rely only on these, along with other sources of outside income. They do not rely on balsamo resin or coffee as primary sources of income. 
Table 6.4.

Total balsamo resin harvest yield (lb) and revenue earned (price/lb in $2009=\mathrm{US} \$ 2.50$, $2010=$ US $\$ 6.00$ ) by the cooperative in $2009 / 2010$ and $2010 / 2011$.

$2009 / 2010 \quad 2010 / 2011$

Balsamo resin yield (lb) $\quad 871 \quad 5,032$

Balsamo resin revenue (US\$) $\quad 2,177 \quad 30,192$

Table 6.5.

Total coffee harvest yield (quintal $=101.2 \mathrm{lbs}$ ) and revenue (price/101.2 lbs) the cooperative earned in 2009 and 2010.

\begin{tabular}{lcr} 
& 2009 & 2010 \\
\hline Coffee yield (quintales) & 130 & 659.70 \\
Coffee revenue (US\$) & 12,129 & 105,354 \\
\hline
\end{tabular}

The cooperative's total balsamo resin harvest yield and revenue they earned from the balsamo resin harvest in 2009/2010 and 2010/2011 are presented in Table 6.4. The cooperative's total coffee harvest yield and price they earned from the coffee harvest in 2009 and 2010 are presented in Table 6.5.

The two tables above demonstrate that the cooperative earned a total of US\$135,446 in balsamo resin and coffee for 2010. If in 2010 the coffee farms were converted to only non balsamo cover type (assuming 50\% of the farm is non balsamo cover type), the yield in coffee would increase by $17 \%$ resulting in US $\$ 114,650$ for total 
value. An increase of $8.8 \%$ in revenue in coffee yield would be the result. A $15 \%$ decrease in total revenue of coffee and balsamo resin from the original revenue of US\$135,546 would be the resulting loss in total revenue for the cooperative. While this result would give farmers and the cooperative an increase in yield in coffee and revenue for only the coffee, they would only be relying on coffee as the primary income source and would lack the secondary source of income, balsamo resin (Table 6.6).

If in 2010 the coffee farms were converted to only balsamo cover type (assuming $50 \%$ of the farm is balsamo cover type), the yield in coffee would decrease by $15 \%$ resulting in US\$97452 for total value in coffee. While this is a decrease in coffee revenue, the cooperative and farmers would still have the extra income of balsamo resin. The balsamo resin revenue would increase by $90 \%$ if coffee farms were converted to balsamo cover type giving the cooperative US\$57,364 in revenue for the balsamo resin. In addition to coffee revenue, the total revenue for both balsamo resin and coffee would be US $\$ 154,817$. An increase in $14 \%$ of total coffee and balsamo resin revenue resulting in US $\$ 154,817$ total revenue from the original revenue of US $\$ 135,546$ would increase total revenue for the cooperative and community (Table 6.7). As a result it would not benefit the cooperative to convert to $100 \%$ non balsamo cover type because of the loss in income the balsamo resin provides for them. Converting to $100 \%$ balsamo cover type would decrease the yield in coffee slightly, but the cooperative would benefit from the income gain in balsamo resin while still having a slightly lower coffee yield income. This would benefit the cooperative and the community because both primary sources of income would still be available. Converting to only non balsamo cover type would only increase the income of coffee and cancel out all balsamo resin income. 


\section{Table 6.6.}

Hypothetical revenue of coffee yield and balsamo resin in 2010 if coffee farms were converted to non balsamo cover type compared to original revenue of 2010 .

Hypothetical Revenue 2010 Original Revenue 2010

\begin{tabular}{lrc}
$\begin{array}{l}\text { Coffee revenue } \\
\text { (US\$) }\end{array}$ & 114,649 & 105,354 \\
$\begin{array}{l}\text { Balsamo resin } \\
\text { revenue (US\$) }\end{array}$ & 0 & 30,192 \\
$\begin{array}{l}\text { Total revenue } \\
\text { (US\$) }\end{array}$ & 114,649 & 135,546 \\
\hline
\end{tabular}

Table 6.7.

Hypothetical revenue of coffee yield and balsamo resin in 2010 if coffee farms were converted to balsamo cover type compared to original revenue of 2010.

Hypothetical Revenue 2010 Original Revenue 2010

\begin{tabular}{lcc}
$\begin{array}{l}\text { Coffee revenue } \\
\text { (US\$) }\end{array}$ & 97,452 & 105,354 \\
$\begin{array}{l}\text { Balsamo resin } \\
\text { revenue (US\$) }\end{array}$ & 57,364 & 30,192 \\
$\begin{array}{l}\text { Total revenue } \\
\text { (US\$) }\end{array}$ & 154,817 & 135,546 \\
\hline
\end{tabular}

The cooperative plays an integral part in the livelihood of the farmers, especially with balsamo resin and coffee. Since the land where the coffee and balsamo is located is owned by the cooperative, farmers rely on it for work. The cooperative is important to the community because it provides the two primary sources of income. 
The cooperative also gives socios land to grow their crops, even though crops are not considered a primary source of income according to the farmers. Farmers use what they earn from crops for consumption, paying off debts and for emergencies within the household. While crops do not provide much income for the farmers, they are advantageous in that farmers save money on main food staples such as maize, beans and rice they would otherwise buy outside the community. The sorghum and maize harvested is used for fodder for chickens and pigs kept within the household, this also minimizes what they would spend if they had to purchase these products outside of the community.

The community is poor, but because of the cooperative, farmers earn sufficient income to provide for their families. Women also play a role generating income for their households. Besides migrating outside of the community for work, women sell fruits, vegetables and animals to community members. A governmental organization also provides women who send their children to school and medical exams with a bimonthly stipend of US\$30-40 for attending monthly educational lectures given within the community. A combination of what women and farmers make for their families within the community is enough to sustain a household.

The cooperative is currently trying to repay a debt from the early nineties and if it is not repaid, could put their land in jeopardy. The cooperative has a debt of approximately US\$70,000 and are only able to pay off the accrued annual interest. If unable to repay the entire debt, they risk losing parcels of land to the bank and the Institute of Agrarian Transformation who would then own the land. Community members in El Balsamar would not have to worry about losing their homes, but they would have to worry about losing work in coffee farms and balsamo plots. All of this would signify a 
loss in the two primary sources of income for the community. If this happened, community members would rely on the other two sources of income, crops and migratory work. As stated before, crops are used for emergency purchases and consumption and generate little income. Therefore a reliance on migratory work would be the main income source for those that do not receive remittances.

Balsamo resin could be viewed as the most valuable source of income for some community members, but the cooperative is the primary source of this income. The cooperative is the key factor in the well-being of the community household. Without the cooperative, the community would not have the work security they do with balsamo resin and coffee and without the community, the cooperative would not have the community labor force to slowly repay the cooperative's debt. 


\section{Chapter 7 - Conclusions}

El Balsamar consists of a community of families and a cooperative. Both play an integral part in each other's lives. The community relies on the cooperative for their source of income within the community and the cooperative relies on the community for labor to continue their work with balsamo resin and coffee to help them eventually pay off their debt. Although El Balsamar could be considered a poor community, the families live relatively well and are able to pay for their basic household needs. Households have other sources of income as well when market prices of balsamo resin and coffee are low. All farmers have fields to grow their crops. Crops are not seen as a significant source of income, but they help households pay off their debts and provide money for emergencies. They also provide food for the household which would otherwise be bought in town. The farmer saves money when he is able to grow his own food for his family. Women's role in income generation plays an important component in maintaining the household. Women usually migrate to larger cities to work and, although there is cost in transportation, housing and food, it provides additional income while the husband remains in the community to grow his crops. Women also sell fruits, vegetables and animals to community members. This allows them to stay in the community and take care of the household. While women generally migrate outside of the community for work, men remain in the community to work balsamo resin and coffee. 
This study was conducted based upon farmers' beliefs that coffee yields were lower under balsamo cover type and coffee is better suited under non balsamo cover type. Using statistical tests and interviews with farmers, this belief was found to be correct.

Farmers still continue to manage coffee under balsamo cover type even though they believe it decreases coffee yield. Interviews with farmers reinforced why they continue this. One hundred percent of the farmer's interviewed said what they lose in the coffee harvest is compensated for by balsamo resin harvest. Balsamo is seen as a multipurpose tree intercropped with coffee and farmers are willing to take the loss in coffee yield for the benefits that the resin gives them. Extracting balsamo resin is considered more involved than coffee harvesting, but the individual farmer earns more from balsamo resin compared to what he earns from a coffee harvest.

It would be beneficial for future studies to measure more environmental variability within the coffee farms. In the present study, only weight of coffee beans harvested from each coffee tree was recorded, coffee tree height and diameter were measured, light measurements were taken under balsamo cover type and non balsamo cover type, and basal area of balsamo cover type and non balsamo cover type was measured.

Market prices in balsamo resin and coffee fluctuate causing the farmers' households and the cooperative to struggle to provide for themselves and their families. Since it has been concluded that non balsamo cover type has higher coffee yields compared to balsamo cover type, it may benefit the cooperative to intensify coffee management in areas with non balsamo cover type to increase coffee yield and continue 
managing the same way under balsamo cover type since the balsamo resin compensates for what is lost in coffee income. The balsamo trees' benefits for the community far outweigh those of the non balsamo cover type and for the relatively small difference in coffee yield between the two cover types. It is recommended the cooperative/farmers either continue their current management practices or convert more farms to balsamo cover type to increase their balsamo resin yield income. Although this results in lower coffee yield, the cooperative and farmers would still benefit from having both primary sources of income.

The community of El Balsamar has been working with coffee and extracting balsamo resin for more than 100 years. With the fall in price of coffee and balsamo resin from time to time, community members remain strong and search for other means to provide for their families. The community has the will to push forward with their lives regardless of their income source. With the community and cooperative working as an integral unit it is possible they will overcome their hardships and face an unforeseen future with self-reliance and integrity with the work they have been performing for over a century. 


\section{Works Cited}

Altieri MA. 2000. Applying Agroecology to Enhance the Productivity of Peasant Farming Systems in Latin America. Environment, Development and Sustainability. 1: 200-203.

Avery TE, Burkhart HE. 1983. Forest Measurements. 3rd ed. New York (NY): McGrawHill Inc.

Beer J, Muschler R, Kass D, Somarriba E. 1998. Shade Management in Coffee and Cacao Plantations. Agroforestry Systems. 38:139-140.

Beer J. 1987. Advantages, disadvantages and desirable characteristics of shade trees for coffee, cacao and tea. Agroforestry Systems. 5:4-5.

Bernard HR. 2002. Research Methods in Anthropology: Qualitative and Quantitative Approaches. 3rd ed. Walnut Creek (CA): Altamira Press.

Boa E, Bentley JW, Stonehouse J. 2001. Standing On All Three Legs: The Technico As A Cross-Cultural Occupational Group. Economic Botany. 55(3):363-369.

Browning D. 1983. Agrarian Reform in El Salvador. Journal of Latin American Studies. 15(2):399-417.

Canales HG. 1984. Balsamo de El Salvador. San Salvador (El Salvador): Ministerio de Educacion Direccion de Publicaciones.

CIA - The World Factbook [Internet]. 2012. Washington (DC): Central Intelligence Agency. The World Factbook: El Salvador; [updated 2012 Feb 17, cited 2012 Feb 23]. Available from: https://www.cia.gov/library/publications/the-worldfactbook/geos/es.html 
Dorset B. 2008. Agricultural Intensification, Diversification, and Commercial Production among Smallholder Coffee Growers in Central Kenya. Economic Geography. 75(2):178-180.

Foley E, Rafiz H. 1995. Cultures of the World: El Salvador. Tarrytown (NY): Marshall Cavendish Benchmark.

Godoy R, Bennett C. 1989. Diversification among Coffee Smallholders in the Highlands of South Sumatra, Indonesia. Human Ecology. 16(4):410-414.

Guest G, Bunce A, Johnson L. 2006. How Many Interviews Are Enough? An Experiment with Data Saturation and Variability. Field Methods. 18:59-82.

Herzog F. 1994. Multipurpose Shade Trees in Coffee and Cocoa Plantations in Cote d' Ivoire. Agroforestry Systems. 27: 260-266.

ICO - Coffee Prices [Internet]. 2012. London (England): International Coffee Organization. Coffee Prices: Monthly Averages; [ cited 2012 Mar 13]. Available from: http://www.ico.org/prices/p2.htm

Ministry of Agriculture El Salvador [Internet]. 2011. Santa Tecla (El Salvador): Ministry of Agriculture and Livestock. Retrospectiva Granos Basicos; [cited 2012 Feb 25]. Available from:

http://www.mag.gob.sv/index.php?option=com_phocadownload\&view=category \&id=22\&Itemid $=233$

MPI - Country Profiles [Internet]. 2012. Washington (DC): Migration Policy Institute. Country Profiles: El Salvador; [cited 2012 Feb 28]. Available from: http://www.migrationinformation.org/Profiles/display.cfm?ID=636

Nolasco MA. 1985. Café y sociedad en Mexico. Altadena 8 (Mexico): Centro de Ecodesarrollo.

Parker T. 2008. Trees of Guatemala. Austin(TX): The Tree Press. 
Pelupessy W. 1997. The Limits of Economic Reform in El Salvador. New York (NY): St. Martin's Press INC.

Pinto LS, Hernandez JC, Nieto JC. 2000. Shade effect on coffee production at the northern Tzeltal zone of the state of Chiapas, Mexico. Agriculture, Ecosystems and Environment. 80(1-2):61-69.

PROCAFE - El Salvador Land of Coffee [Internet]. 2004. Santa Tecla (El Salvador): The Salvadoran Foundation for Coffee Research; [cited 2012 Feb 3]. Available from: http://www.procafe.com.sv/menu/ArchivosPDF/landofcoffee.pdf

Snedecor GW, Cochran WG. 1989. Statistical Methods. 8th ed. Ames (IA): Iowa State Press.

SNET - La Dinámica Socio-Económica del Territorio [Internet]. 2006. San Salvador (El Salvador): Servicio Nacional de Estudios Territoriales; [cited 2012 Feb 6]. Available from: www.snet.gob.sv/Riesgo/.../Sonsonate-Izalco.pdf

SNET. 2006. Western El Salvador rain data excel file. Servicio Nacional de Estudios Territoriales. San Salvador (El Salvador).

Steel RG, Torrie JH. 1960. Principles and Procedures of Statistics. New York(NY): McGraw-Hill.

Strasma J, Gore P, Nash J, Rochin RI. 1983. Agrarian Reform in El Salvador. Washington (DC): Checchi and Company.

Stratton SW. Undated. El Proceso de Extraccion de la Resina de Balsamo en El Canton El Balsamar. U.S. Peace Corps, San Salvador, El Salvador.

Suarez F. 1960. Relationships Between Rainfall and Coffee Production. Coffee Costa Rica. 2(7):85-90.

Thrupp LA. 1998. Cultivating Diversity Agro biodiversity and Food Security. Washington (DC): World Resources Institute. 
U.S. Department of State - Bureau of Public Affairs: Electronic Information and Publication [Internet]. 2012. Washington (DC): Bureau of Public Affairs: Electronic Information and Publication: Background Notes: El Salvador [cited Feb 24]. Available from: http://www.state.gov/r/pa/ei/bgn/2033.htm

University of Texas - Maps of the Americas [Internet]. 2012. Austin (TX): University of Texas. Maps of the Americas: El Salvador Shaded relief Map [updated 2012 Feb 3, cited 2012 Feb 8]. Available from:

http://www.lib.utexas.edu/maps/americas/elsalvador.jpg

USDA Forest Service - FIA Library [Internet]. 2007. Arlington (VA): Forest Inventory and Analysis National Core Field Guide Volume 1: Field Data Collection Procedures for Phase 2 Plots; [updated 2011 Oct 27, cited 2012 Feb2] Available from: http://www.fia.fs.fed.us/library/field-guides-methodsproc/docs/core_ver_4-0_10_2007_p2.pdf

World Agroforestry Database - Agroforestree Database:a tree reference and selection guide version 4.0 [Internet]. 2009. Nairobi (Kenya): Agroforestry Database: a tree reference and selection guide version 4.0 Myroxylon balsamum [cited 2012 Feb 3) Available from: http://www.worldagroforestry.org/treedb2/AFTPDFS/Myroxylon_balsamum.pdf Wrigley G. 1988. Coffee. New York (NY): Longman Scientific and Technical. 


\title{
Appendix A - Research Consent Form and Survey
}

\author{
Written Research Consent Form \\ English
}

In addition to my duties as a forestry extension Peace Corps Volunteer, I am writing a report as part of my education at my university. I would like to talk to you from time to time about some of your experiences with coffee and balsamo production. I may use what you tell me in my written report to my professors at my university. I will have some particular things I would like to talk about but you may ask me questions and talk about things you think I should know about, even if I don't ask. You are not required to talk to me or answer my questions. I will not identify you personally unless you allow me to. Even if you decide now to talk to me about coffee plantations, you may later ask me to stop asking you about it. When you ask me to stop, I will stop asking you about your coffee plantation. You decide if you want to talk to me about it. Nothing bad will happen to you or to me if you decide not to answer my questions about coffee and balsamo production. 


\section{Written Research Consent Form}

\section{Spanish}

En adicion de mis funciones trabajando como un Voluntario de Cuerpo de Paz en el area agricola forestal, estoy escribiendo un reporte como parte de mi educacion universitaria. Yo quisiera hablarle de vez en cuando sobre algunas de sus experiencias con la produccion del café y balsamo. Es possible que lo que me diga sea escrito en el reporte para mi professor en la Universidad. Yo tendre algunas preguntas en particular que quisiera hacerle pero usted esta en toda liberta de darme cualquier otra informacion que crea necesaria para el reporte aunque no le pregunte. No sera identificado personalmente al menos que me lo permita. Aunque usted decida hablarmen ahora sobre la fincas cafeteras, es su derecho de pedirme que no continue haciendo preguntas sobre el tema en el futuro. Cuando me pida que no le haga mas preguntas sobre las fincas cafeteras, yo dejare de hacerle cualquier pregunta sobre el tema. Ni ustede ni yo tendremos ninguga repercucion si usted ya no quiere contestar las preguntas sobre la produccion del café y balsamo. 


\section{Interview Questions for the Cooperative of El Balsamar}

1. What is the spacing planted between coffee trees?

2. What types of techniques are used to manage the coffee farms (e.g. pruning, fertilizing, etc)?

3. Was fertilizer applied to the farms in 2009 and 2010 ?

4. If not, do you believe this affected coffee yield in the year they were not fertilized?

5. Do you believe that rain affects the outcome of the yield of coffee?

6. If yes, what do you believe to be the principal reason for this?

7. To whom does the cooperative sell balsamo resin?

8. To whom does the cooperative sell the coffee harvest?

9. Was the revenue from coffee from 2009 better or worse than in 2010 ?

10. What do you believe to be the reason for this?

\section{Interview Questions for Farmers}

1. What is the history of balsamo production in the commmunity?

2. When did the community begin to extract balsamo resin?

3. How long has the community been using balsamo resin?

4. How long has the community been using balsamo resin commercially?

5. What is the history of coffee management in the community?

6. When did the community begin to manage coffee? 
7. How long have people in the community been growing crops?

8. What dates does the community work balsamo, coffee and crops?

9. Do prices of balsamo resin and coffee change every year?

10. Does the type of work change every year for balsamo and coffee? Do workers change?

11. Do migrant workers earnings change every year?

12. How much do prices change with basic grains every year (e.g. maize, beans, rice, sorghum)?

13. How do these prices of balsamo, coffee and crops affect farmers' households?

14. If prices of coffee, balsamo and crops are low, how does it affect farmers' households?

15. What are the similarities and differences between balsamo and coffee management? Is one more difficult than the other?

16. Is balsamo production occur during the same time as coffee production and/or crop production?

17. What is balsamo used for?

18. Other than shade. What are the other benefits of non balsamo trees if any?

19. Do you believe the shade from the balsamo tree promotes coffee production?

20. If you believe it does, why not take out balsamo and introduce better trees? 


\section{Appendix B - SAS Code Used in the Data Analysis}

Correlation SAS

PROC CORR ;

VAR BAL1 DWTBAL1 DIABAL1 HTBAL1 LGTBAL1 BABAL1;

RUN;

Paired T-Test

proc TTEST;

paired DWBAL1*DWXBAL1;

proc end; 


\section{Appendix C - Tabular Data Set of Balsamo/Non Balsamo Cover Type Data Set}

Table C.1.

Complete data set of field study balsamo cover type 2009

\begin{tabular}{|c|c|c|c|c|c|}
\hline FARM & BALSAMO & YEAR 1 & TREE & DRY WEIGHT( KG) & HEIGHT( M) \\
\hline 1 & 1 & 0 & 1 & 0.11 & 2.3 \\
\hline 1 & 1 & 0 & 2 & 0.06 & 2.45 \\
\hline 1 & 1 & 0 & 3 & 0.06 & 2.4 \\
\hline 1 & 1 & 0 & 4 & 0.09 & 2.56 \\
\hline 2 & 1 & 0 & 1 & 0.06 & 2.3 \\
\hline 2 & 1 & 0 & 2 & 0.09 & 2.95 \\
\hline 2 & 1 & 0 & 3 & 0.05 & 1.9 \\
\hline 2 & 1 & 0 & 4 & 0.09 & 2.43 \\
\hline 3 & 1 & 0 & 1 & 0.06 & 1.9 \\
\hline 3 & 1 & 0 & 2 & 0.09 & 2.45 \\
\hline 3 & 1 & 0 & 3 & 0.15 & 2.6 \\
\hline 3 & 1 & 0 & 4 & 0.13 & 2.5 \\
\hline 4 & 1 & 0 & 1 & 0.09 & 2.2 \\
\hline 4 & 1 & 0 & 2 & 0.21 & 2.81 \\
\hline 4 & 1 & 0 & 3 & 0.09 & 2.62 \\
\hline 4 & 1 & 0 & 4 & 0.21 & 3.05 \\
\hline 6 & 1 & 0 & 1 & 0.12 & 3.45 \\
\hline 6 & 1 & 0 & 2 & 0.05 & 3 \\
\hline 6 & 1 & 0 & 3 & 0.12 & 3.45 \\
\hline 6 & 1 & 0 & 4 & 0.31 & 3.5 \\
\hline 8 & 1 & 0 & 1 & 0.04 & 3.14 \\
\hline 8 & 1 & 0 & 2 & 0.12 & 3.05 \\
\hline 8 & 1 & 0 & 3 & 0.12 & 3.25 \\
\hline 8 & 1 & 0 & 4 & 0.03 & 2.95 \\
\hline 10 & 1 & 0 & 1 & 0.03 & 3.1 \\
\hline 10 & 1 & 0 & 2 & 0.01 & 2.7 \\
\hline 10 & 1 & 0 & 3 & 0.06 & 3.1 \\
\hline 10 & 1 & 0 & 4 & 0.1 & 2.25 \\
\hline
\end{tabular}

Continued on next page. 


$\begin{array}{cccccc}\text { FARM } & \text { BALSAMO } & \text { YEAR 1 } & \text { TREE } & \text { DRY WEIGHT( KG) } & \text { HEIGHT( M) } \\ 23 & 1 & 0 & 1 & 0.07 & 2.15 \\ 23 & 1 & 0 & 2 & 0.1 & 4 \\ 23 & 1 & 0 & 3 & 0.1 & 3.5 \\ 23 & 1 & 0 & 4 & 0.06 & 2.8 \\ 24 & 1 & 0 & 1 & 0.12 & 3.15 \\ 24 & 1 & 0 & 2 & 0.09 & 3.25 \\ 24 & 1 & 0 & 3 & 0.06 & 3.3 \\ 24 & 1 & 0 & 4 & 0.04 & 2.45 \\ 25 & 1 & 0 & 1 & 0.06 & 2.18 \\ 25 & 1 & 0 & 2 & 0.04 & 2.2 \\ 25 & 1 & 0 & 3 & 0.18 & 2.25 \\ 25 & 1 & 0 & 4 & 0.15 & 2.3 \\ 26 & 1 & 0 & 1 & 0.16 & 1.7 \\ 26 & 1 & 0 & 2 & 0.04 & 1.25 \\ 26 & 1 & 0 & 3 & 0.13 & 1.95 \\ 26 & 1 & 0 & 4 & 0.04 & 1.97 \\ 27 & 1 & 0 & 1 & 0.27 & 2.63 \\ 27 & 1 & 0 & 2 & 0.21 & 2.27 \\ 27 & 1 & 0 & 3 & 0.15 & 2.57 \\ 27 & 1 & 0 & 4 & 0.12 & 2.9 \\ 28 & 1 & 0 & 1 & 0.12 & 3.3 \\ 28 & 1 & 0 & 2 & 0.12 & 3.2 \\ 28 & 1 & 0 & 3 & 0.06 & 3.4 \\ 28 & 1 & 0 & 4 & 0.07 & 2\end{array}$

Continued on next page. 


\begin{tabular}{|c|c|c|c|c|c|}
\hline FARM & BALSAMO & YEAR 1 & TREE & DIAMETER (CM) & LIGHT (KLUX) \\
\hline 1 & 1 & 0 & 1 & 10 & 1.12 \\
\hline 1 & 1 & 0 & 2 & 8 & 27 \\
\hline 1 & 1 & 0 & 3 & 9 & 1.85 \\
\hline 1 & 1 & 0 & 4 & 8 & 6 \\
\hline 2 & 1 & 0 & 1 & 9 & 2.3 \\
\hline 2 & 1 & 0 & 2 & 10 & 2.8 \\
\hline 2 & 1 & 0 & 3 & 8 & 2.3 \\
\hline 2 & 1 & 0 & 4 & 11 & 2.4 \\
\hline 3 & 1 & 0 & 1 & 8 & 1.88 \\
\hline 3 & 1 & 0 & 2 & 9 & 4.5 \\
\hline 3 & 1 & 0 & 3 & 10 & 2.5 \\
\hline 3 & 1 & 0 & 4 & 10 & 1.6 \\
\hline 4 & 1 & 0 & 1 & 11 & 11.5 \\
\hline 4 & 1 & 0 & 2 & 11 & 1.7 \\
\hline 4 & 1 & 0 & 3 & 11 & 0.5 \\
\hline 4 & 1 & 0 & 4 & 11 & 1.25 \\
\hline 6 & 1 & 0 & 1 & 17 & 0.39 \\
\hline 6 & 1 & 0 & 2 & 11 & 0.6 \\
\hline 6 & 1 & 0 & 3 & 12 & 0.6 \\
\hline 6 & 1 & 0 & 4 & 12 & 0.66 \\
\hline 8 & 1 & 0 & 1 & 11 & 1.5 \\
\hline 8 & 1 & 0 & 2 & 11 & 1 \\
\hline 8 & 1 & 0 & 3 & 13 & 0.99 \\
\hline 8 & 1 & 0 & 4 & 11 & 2 \\
\hline 10 & 1 & 0 & 1 & 11 & 0.52 \\
\hline 10 & 1 & 0 & 2 & 8 & 0.6 \\
\hline 10 & 1 & 0 & 3 & 13 & 0.25 \\
\hline 10 & 1 & 0 & 4 & 12 & 0.3 \\
\hline 23 & 1 & 0 & 1 & 19 & 2.4 \\
\hline 23 & 1 & 0 & 2 & 25 & 2 \\
\hline 23 & 1 & 0 & 3 & 19 & 1.74 \\
\hline 23 & 1 & 0 & 4 & 35 & 14.2 \\
\hline
\end{tabular}

Continued on next page. 


$\begin{array}{cccccc}\text { FARM } & \text { BALSAMO } & \text { YEAR } 1 & \text { TREE } & \text { DIAMETER (CM) } & \text { LIGHT (KLUX) } \\ 24 & 1 & 0 & 1 & 18 & 38 \\ 24 & 1 & 0 & 2 & 23 & 27.07 \\ 24 & 1 & 0 & 3 & 18 & 7.14 \\ 24 & 1 & 0 & 4 & 19 & 84.2 \\ 25 & 1 & 0 & 1 & 12 & 2.21 \\ 25 & 1 & 0 & 2 & 14 & 2.05 \\ 25 & 1 & 0 & 3 & 12 & 2 \\ 25 & 1 & 0 & 4 & 15 & 5.61 \\ 26 & 1 & 0 & 1 & 13 & 81.3 \\ 26 & 1 & 0 & 2 & 14 & 10 \\ 26 & 1 & 0 & 3 & 14 & 61 \\ 26 & 1 & 0 & 4 & 12 & 60 \\ 27 & 1 & 0 & 1 & 22 & 1.43 \\ 27 & 1 & 0 & 2 & 11 & 4.2 \\ 27 & 1 & 0 & 3 & 25 & 3.25 \\ 27 & 1 & 0 & 4 & 17 & 1.05 \\ 28 & 1 & 0 & 1 & 17 & 1.3 \\ 28 & 1 & 0 & 2 & 16 & 3.6 \\ 28 & 1 & 0 & 3 & 18 & 2.33 \\ 28 & 1 & 0 & 4 & 24 & \end{array}$




\begin{tabular}{cccc} 
FARM & BALSAMO & YEAR 1 & BA BALSAMO YEAR 1 \\
1 & 1 & 0 & 22.69 \\
1 & 1 & 0 & 22.69 \\
1 & 1 & 0 & 22.69 \\
1 & 1 & 0 & 22.69 \\
2 & 1 & 0 & 31.22 \\
2 & 1 & 0 & 31.22 \\
2 & 1 & 0 & 31.22 \\
2 & 1 & 0 & 31.22 \\
3 & 1 & 0 & 24.10 \\
3 & 1 & 0 & 24.10 \\
3 & 1 & 0 & 24.10 \\
3 & 1 & 0 & 24.10 \\
4 & 1 & 0 & 22.96 \\
4 & 1 & 0 & 22.96 \\
4 & 1 & 0 & 22.96 \\
4 & 1 & 0 & 22.96 \\
6 & 1 & 0 & 25.25 \\
6 & 1 & 0 & 25.25 \\
6 & 1 & 0 & 25.25 \\
6 & 1 & 0 & 25.25 \\
8 & 1 & 0 & 24.49 \\
8 & 1 & 0 & 24.49 \\
8 & 1 & 0 & 24.49 \\
8 & 1 & 0 & 24.49 \\
10 & 1 & 0 & 22.96 \\
10 & 1 & 0 & 22.96 \\
10 & 1 & 0 & 22.96 \\
10 & 1 & 0 & 22.96 \\
23 & 1 & 0 & 24.49 \\
23 & 1 & 0 & 24.49 \\
23 & 1 & 0 & 24.49 \\
23 & 1 & 0 & 24.49 \\
\hline & 1 &
\end{tabular}

Continued on next page. 


$\begin{array}{cccc}\text { FARM } & \text { BALSAMO } & \text { YEAR 1 } & \text { BA BALSAMO YEAR 1 } \\ 24 & 1 & 0 & 18.37 \\ 24 & 1 & 0 & 18.37 \\ 24 & 1 & 0 & 18.37 \\ 24 & 1 & 0 & 18.37 \\ 25 & 1 & 0 & 22.96 \\ 25 & 1 & 0 & 22.96 \\ 25 & 1 & 0 & 22.96 \\ 25 & 1 & 0 & 22.96 \\ 26 & 1 & 0 & 22.96 \\ 26 & 1 & 0 & 22.96 \\ 26 & 1 & 0 & 22.96 \\ 26 & 1 & 0 & 22.96 \\ 27 & 1 & 0 & 19.90 \\ 27 & 1 & 0 & 19.90 \\ 27 & 1 & 0 & 19.90 \\ 27 & 1 & 0 & 19.90 \\ 28 & 1 & 0 & 20.66 \\ 28 & 1 & 0 & 20.66 \\ 28 & 1 & 0 & 20.66 \\ 28 & 1 & 0 & 20.66\end{array}$


Table C.2.

Complete data set of field study balsamo cover type 2010

\begin{tabular}{|c|c|c|c|c|c|}
\hline FARM & BALSAMO & YEAR 2 & TREE & DRY WEIGHT( KG) & HEIGHT( M) \\
\hline 1 & 1 & 1 & 5 & 0.09 & 2.8 \\
\hline 1 & 1 & 1 & 6 & 0.12 & 3.18 \\
\hline 1 & 1 & 1 & 7 & 0.12 & 3.08 \\
\hline 1 & 1 & 1 & 8 & 0.09 & 3.19 \\
\hline 2 & 1 & 1 & 5 & 0.15 & 3.01 \\
\hline 2 & 1 & 1 & 6 & 0.12 & 2.71 \\
\hline 2 & 1 & 1 & 7 & 0.06 & 2.25 \\
\hline 2 & 1 & 1 & 8 & 0.12 & 2.38 \\
\hline 3 & 1 & 1 & 5 & 0.09 & 1.97 \\
\hline 3 & 1 & 1 & 6 & 0.12 & 2.01 \\
\hline 3 & 1 & 1 & 7 & 0.12 & 3.08 \\
\hline 3 & 1 & 1 & 8 & 0.12 & 2.46 \\
\hline 4 & 1 & 1 & 5 & 0.09 & 2.08 \\
\hline 4 & 1 & 1 & 6 & 0.15 & 2.36 \\
\hline 4 & 1 & 1 & 7 & 0.06 & 1.97 \\
\hline 4 & 1 & 1 & 8 & 0.09 & 2.67 \\
\hline 5 & 1 & 1 & 5 & 0.12 & 3.21 \\
\hline 5 & 1 & 1 & 6 & 0.09 & 3.95 \\
\hline 5 & 1 & 1 & 7 & 0.06 & 3.42 \\
\hline 5 & 1 & 1 & 8 & 0.06 & 3.66 \\
\hline 6 & 1 & 1 & 5 & 0.09 & 4.11 \\
\hline 6 & 1 & 1 & 6 & 0.12 & 3.48 \\
\hline 6 & 1 & 1 & 7 & 0.12 & 4.59 \\
\hline 6 & 1 & 1 & 8 & 0.27 & 3.2 \\
\hline 7 & 1 & 1 & 5 & 0.09 & 3.89 \\
\hline 7 & 1 & 1 & 6 & 0.09 & 2.35 \\
\hline 7 & 1 & 1 & 7 & 0.06 & 2.27 \\
\hline 7 & 1 & 1 & 8 & 0.12 & 2.75 \\
\hline
\end{tabular}

Continued on next page. 


\begin{tabular}{|c|c|c|c|c|c|}
\hline FARM & BALSAMO & YEAR 2 & TREE & DRY WEIGHT( KG) & HEIGHT( M) \\
\hline 8 & 1 & 1 & 5 & 0.18 & 3.35 \\
\hline 8 & 1 & 1 & 6 & 0.09 & 2.45 \\
\hline 8 & 1 & 1 & 7 & 0.12 & 3.35 \\
\hline 8 & 1 & 1 & 8 & 0.15 & 2.6 \\
\hline 9 & 1 & 1 & 5 & 0.03 & 2.35 \\
\hline 9 & 1 & 1 & 6 & 0.18 & 3.4 \\
\hline 9 & 1 & 1 & 7 & 0.15 & 4.2 \\
\hline 9 & 1 & 1 & 8 & 0.15 & 3.4 \\
\hline 10 & 1 & 1 & 5 & 0.18 & 3.2 \\
\hline 10 & 1 & 1 & 6 & 0.18 & 2.88 \\
\hline 10 & 1 & 1 & 7 & 0.18 & 2.6 \\
\hline 10 & 1 & 1 & 8 & 0.03 & 2.7 \\
\hline 11 & 1 & 1 & 5 & 0.21 & 2.45 \\
\hline 11 & 1 & 1 & 6 & 0.09 & 3.3 \\
\hline 11 & 1 & 1 & 7 & 0.15 & 1.7 \\
\hline 11 & 1 & 1 & 8 & 0.09 & 3.27 \\
\hline 12 & 1 & 1 & 5 & 0.12 & 3.25 \\
\hline 12 & 1 & 1 & 6 & 0.09 & 2.88 \\
\hline 12 & 1 & 1 & 7 & 0.24 & 3.5 \\
\hline 12 & 1 & 1 & 8 & 0.12 & 3.59 \\
\hline 13 & 1 & 1 & 5 & 0.12 & 2.9 \\
\hline 13 & 1 & 1 & 6 & 0.21 & 3.2 \\
\hline 13 & 1 & 1 & 7 & 0.37 & 3.25 \\
\hline 13 & 1 & 1 & 8 & 0.24 & 3.25 \\
\hline 14 & 1 & 1 & 5 & 0.21 & 3.8 \\
\hline 14 & 1 & 1 & 6 & 0.15 & 3.8 \\
\hline 14 & 1 & 1 & 7 & 0.12 & 3.45 \\
\hline 14 & 1 & 1 & 8 & 0.18 & 3.6 \\
\hline 15 & 1 & 1 & 5 & 0.27 & 3.59 \\
\hline 15 & 1 & 1 & 6 & 0.31 & 3.6 \\
\hline 15 & 1 & 1 & 7 & 0.06 & 2.9 \\
\hline 15 & 1 & 1 & 8 & 0.18 & 3.92 \\
\hline
\end{tabular}

Continued on next page. 


\begin{tabular}{|c|c|c|c|c|c|}
\hline FARM & BALSAMO & YEAR 2 & TREE & DRY WEIGHT( KG) & HEIGHT( M) \\
\hline 16 & 1 & 1 & 5 & 0.18 & 3.37 \\
\hline 16 & 1 & 1 & 6 & 0.18 & 3.32 \\
\hline 16 & 1 & 1 & 7 & 0.09 & 3.4 \\
\hline 16 & 1 & 1 & 8 & 0.18 & 3.16 \\
\hline 17 & 1 & 1 & 5 & 0.12 & 3 \\
\hline 17 & 1 & 1 & 6 & 0.12 & 3.11 \\
\hline 17 & 1 & 1 & 7 & 0.24 & 2.95 \\
\hline 17 & 1 & 1 & 8 & 0.24 & 3.07 \\
\hline 18 & 1 & 1 & 5 & 0.31 & 3.23 \\
\hline 18 & 1 & 1 & 6 & 0.21 & 2.81 \\
\hline 18 & 1 & 1 & 7 & 0.43 & 3.2 \\
\hline 18 & 1 & 1 & 8 & 0.24 & 3 \\
\hline 19 & 1 & 1 & 5 & 0.15 & 2.8 \\
\hline 19 & 1 & 1 & 6 & 0.15 & 3.15 \\
\hline 19 & 1 & 1 & 7 & 0.15 & 2.9 \\
\hline 19 & 1 & 1 & 8 & 0.24 & 3.47 \\
\hline 20 & 1 & 1 & 5 & 0.43 & 2.52 \\
\hline 20 & 1 & 1 & 6 & 0.27 & 2.95 \\
\hline 20 & 1 & 1 & 7 & 0.24 & 3.1 \\
\hline 20 & 1 & 1 & 8 & 0.31 & 3.36 \\
\hline 21 & 1 & 1 & 5 & 0.12 & 2.68 \\
\hline 21 & 1 & 1 & 6 & 0.15 & 2.88 \\
\hline 21 & 1 & 1 & 7 & 0.21 & 2.95 \\
\hline 21 & 1 & 1 & 8 & 0.4 & 3.68 \\
\hline 22 & 1 & 1 & 5 & 0.12 & 4.9 \\
\hline 22 & 1 & 1 & 6 & 0.06 & 3.88 \\
\hline 22 & 1 & 1 & 7 & 0.09 & 3.68 \\
\hline 22 & 1 & 1 & 8 & 0.15 & 4.4 \\
\hline 23 & 1 & 1 & 5 & 0.12 & 3.64 \\
\hline 23 & 1 & 1 & 6 & 0.31 & 3.95 \\
\hline 23 & 1 & 1 & 7 & 0.15 & 3.6 \\
\hline 23 & 1 & 1 & 8 & 0.12 & 4.08 \\
\hline
\end{tabular}

Continued on next page. 


$\begin{array}{cccccc}\text { FARM } & \text { BALSAMO } & \text { YEAR } 2 & \text { TREE } & \text { DRY WEIGHT( KG) } & \text { HEIGHT( M) } \\ 24 & 1 & 1 & 5 & 0.27 & 3.65 \\ 24 & 1 & 1 & 6 & 0.15 & 3.27 \\ 24 & 1 & 1 & 7 & 0.24 & 3.16 \\ 24 & 1 & 1 & 8 & 0.12 & 2.07 \\ 25 & 1 & 1 & 5 & 0.37 & 2.63 \\ 25 & 1 & 1 & 6 & 0.46 & 3.14 \\ 25 & 1 & 1 & 7 & 0.55 & 2.89 \\ 25 & 1 & 1 & 8 & 0.31 & 2.43 \\ 26 & 1 & 1 & 5 & 0.31 & 1.98 \\ 26 & 1 & 1 & 6 & 0.06 & 1.76 \\ 26 & 1 & 1 & 7 & 0.06 & 2.13 \\ 26 & 1 & 1 & 8 & 0.24 & 2.19 \\ 27 & 1 & 1 & 5 & 0.49 & 4.6 \\ 27 & 1 & 1 & 6 & 0.15 & 3.45 \\ 27 & 1 & 1 & 7 & 0.06 & 3.6 \\ 27 & 1 & 1 & 8 & 0.12 & 3.53 \\ 28 & 1 & 1 & 5 & 0.46 & 4.05 \\ 28 & 1 & 1 & 6 & 0.12 & 3.45 \\ 28 & 1 & 1 & 7 & 0.21 & 3.75 \\ 28 & 1 & 1 & 8 & 0.09 & 3.15 \\ 29 & 1 & 1 & 5 & 0.12 & 4.05 \\ 29 & 1 & 1 & 6 & 0.24 & 2.67 \\ 29 & 1 & 1 & 7 & 0.24 & 3.52 \\ 29 & 1 & 1 & 8 & 0.06 & 4.3 \\ 30 & 1 & 1 & 5 & 0.06 & 2.7 \\ 30 & 1 & 1 & 6 & 0.03 & 3.85 \\ 30 & 1 & 1 & 7 & 0.06 & \\ 30 & 1 & 1 & 8 & 0.03 & \end{array}$

Continued on next page. 


\begin{tabular}{|c|c|c|c|c|c|}
\hline FARM & BALSAMO & YEAR 2 & TREE & DIAMETER (CM) & LIGHT (KLUX) \\
\hline 1 & 1 & 1 & 5 & 16 & 1.9 \\
\hline 1 & 1 & 1 & 6 & 19 & 1.95 \\
\hline 1 & 1 & 1 & 7 & 27 & 1.5 \\
\hline 1 & 1 & 1 & 8 & 25 & 3.35 \\
\hline 2 & 1 & 1 & 5 & 14 & 5.9 \\
\hline 2 & 1 & 1 & 6 & 12 & 2.3 \\
\hline 2 & 1 & 1 & 7 & 12 & 1.3 \\
\hline 2 & 1 & 1 & 8 & 12 & 3.15 \\
\hline 3 & 1 & 1 & 5 & 15 & 1.05 \\
\hline 3 & 1 & 1 & 6 & 15 & 2.05 \\
\hline 3 & 1 & 1 & 7 & 15 & 1.24 \\
\hline 3 & 1 & 1 & 8 & 13 & 2.05 \\
\hline 4 & 1 & 1 & 5 & 11 & 2.6 \\
\hline 4 & 1 & 1 & 6 & 11 & 1.01 \\
\hline 4 & 1 & 1 & 7 & 9 & 2 \\
\hline 4 & 1 & 1 & 8 & 12 & 1.8 \\
\hline 5 & 1 & 1 & 5 & 20 & 4 \\
\hline 5 & 1 & 1 & 6 & 13 & 0.54 \\
\hline 5 & 1 & 1 & 7 & 30 & 2.82 \\
\hline 5 & 1 & 1 & 8 & 28 & 1.6 \\
\hline 6 & 1 & 1 & 5 & 17 & 1.9 \\
\hline 6 & 1 & 1 & 6 & 13 & 1.7 \\
\hline 6 & 1 & 1 & 7 & 20 & 1.15 \\
\hline 6 & 1 & 1 & 8 & 14 & 8 \\
\hline 7 & 1 & 1 & 5 & 21 & 0.23 \\
\hline 7 & 1 & 1 & 6 & 17 & 0.47 \\
\hline 7 & 1 & 1 & 7 & 15 & 0.48 \\
\hline 7 & 1 & 1 & 8 & 21 & 0.46 \\
\hline 8 & 1 & 1 & 5 & 21 & 1.28 \\
\hline 8 & 1 & 1 & 6 & 19 & 3.15 \\
\hline 8 & 1 & 1 & 7 & 18 & 0.58 \\
\hline 8 & 1 & 1 & 8 & 12 & 7.31 \\
\hline
\end{tabular}

Continued on next page. 


\begin{tabular}{|c|c|c|c|c|c|}
\hline FARM & BALSAMO & YEAR 2 & TREE & DIAMETER (CM) & LIGHT (KLUX) \\
\hline 9 & 1 & 1 & 5 & 17 & 1.9 \\
\hline 9 & 1 & 1 & 6 & 18 & 4 \\
\hline 9 & 1 & 1 & 7 & 23 & 1.1 \\
\hline 9 & 1 & 1 & 8 & 22 & 2 \\
\hline 10 & 1 & 1 & 5 & 15 & 11 \\
\hline 10 & 1 & 1 & 6 & 15 & 7.9 \\
\hline 10 & 1 & 1 & 7 & 15 & 4.2 \\
\hline 10 & 1 & 1 & 8 & 15 & 9 \\
\hline 11 & 1 & 1 & 5 & 18 & 0.6 \\
\hline 11 & 1 & 1 & 6 & 18 & 2.5 \\
\hline 11 & 1 & 1 & 7 & 19 & 30 \\
\hline 11 & 1 & 1 & 8 & 15 & 10.3 \\
\hline 12 & 1 & 1 & 5 & 19 & 1.1 \\
\hline 12 & 1 & 1 & 6 & 23 & 3.3 \\
\hline 12 & 1 & 1 & 7 & 16 & 3.5 \\
\hline 12 & 1 & 1 & 8 & 21 & 2.3 \\
\hline 13 & 1 & 1 & 5 & 19 & 7.1 \\
\hline 13 & 1 & 1 & 6 & 21 & 6.7 \\
\hline 13 & 1 & 1 & 7 & 18 & 7.08 \\
\hline 13 & 1 & 1 & 8 & 25 & 5.8 \\
\hline 14 & 1 & 1 & 5 & 18 & 5.85 \\
\hline 14 & 1 & 1 & 6 & 19 & 2.05 \\
\hline 14 & 1 & 1 & 7 & 18 & 4.25 \\
\hline 14 & 1 & 1 & 8 & 23 & 3.2 \\
\hline 15 & 1 & 1 & 5 & 19 & 10 \\
\hline 15 & 1 & 1 & 6 & 19 & 19 \\
\hline 15 & 1 & 1 & 7 & 27 & 5.2 \\
\hline 15 & 1 & 1 & 8 & 17 & 2.39 \\
\hline 16 & 1 & 1 & 5 & 18 & 2.5 \\
\hline 16 & 1 & 1 & 6 & 26 & 2.95 \\
\hline 16 & 1 & 1 & 7 & 23 & 4.6 \\
\hline 16 & 1 & 1 & 8 & 23 & 2.33 \\
\hline
\end{tabular}

Continued on next page. 


\begin{tabular}{|c|c|c|c|c|c|}
\hline FARM & BALSAMO & YEAR 2 & TREE & DIAMETER (CM) & LIGHT (KLUX) \\
\hline 17 & 1 & 1 & 5 & 16 & 1.91 \\
\hline 17 & 1 & 1 & 6 & 19 & 1.75 \\
\hline 17 & 1 & 1 & 7 & 17 & 4.9 \\
\hline 17 & 1 & 1 & 8 & 19 & 10 \\
\hline 18 & 1 & 1 & 5 & 26 & 3 \\
\hline 18 & 1 & 1 & 6 & 26 & 2.75 \\
\hline 18 & 1 & 1 & 7 & 17 & 2.3 \\
\hline 18 & 1 & 1 & 8 & 26 & 3 \\
\hline 19 & 1 & 1 & 5 & 35 & 3.6 \\
\hline 19 & 1 & 1 & 6 & 15 & 1.75 \\
\hline 19 & 1 & 1 & 7 & 20 & 2.2 \\
\hline 19 & 1 & 1 & 8 & 20 & 1.8 \\
\hline 20 & 1 & 1 & 5 & 26 & 8.12 \\
\hline 20 & 1 & 1 & 6 & 26 & 7 \\
\hline 20 & 1 & 1 & 7 & 22 & 6.6 \\
\hline 20 & 1 & 1 & 8 & 22 & 14 \\
\hline 21 & 1 & 1 & 5 & 21 & 5.35 \\
\hline 21 & 1 & 1 & 6 & 29 & 4 \\
\hline 21 & 1 & 1 & 7 & 28 & 2.15 \\
\hline 21 & 1 & 1 & 8 & 23 & 10.3 \\
\hline 22 & 1 & 1 & 5 & 45 & 1.3 \\
\hline 22 & 1 & 1 & 6 & 38 & 1.15 \\
\hline 22 & 1 & 1 & 7 & 37 & 10 \\
\hline 22 & 1 & 1 & 8 & 29 & 1.75 \\
\hline 23 & 1 & 1 & 5 & 16 & 1.05 \\
\hline 23 & 1 & 1 & 6 & 20 & 1.07 \\
\hline 23 & 1 & 1 & 7 & 19 & 2.5 \\
\hline 23 & 1 & 1 & 8 & 19 & 5.5 \\
\hline 24 & 1 & 1 & 5 & 30 & 0.83 \\
\hline 24 & 1 & 1 & 6 & 20 & 1.6 \\
\hline 24 & 1 & 1 & 7 & 20 & 0.92 \\
\hline 24 & 1 & 1 & 8 & 17 & 0.79 \\
\hline
\end{tabular}

Continued on next page. 


$\begin{array}{cccccc}\text { FARM } & \text { BALSAMO } & \text { YEAR } 2 & \text { TREE } & \text { DIAMETER }(\mathrm{CM}) & \text { LIGHT (KLUX) } \\ 25 & 1 & 1 & 5 & 15 & 9.9 \\ 25 & 1 & 1 & 6 & 19 & 0.54 \\ 25 & 1 & 1 & 7 & 16 & 2.35 \\ 25 & 1 & 1 & 8 & 16 & 1 \\ 26 & 1 & 1 & 5 & 19 & 10 \\ 26 & 1 & 1 & 6 & 12 & 0.34 \\ 26 & 1 & 1 & 7 & 15 & 3 \\ 26 & 1 & 1 & 8 & 14 & 0.32 \\ 27 & 1 & 1 & 5 & 22 & 9.5 \\ 27 & 1 & 1 & 6 & 42 & 20 \\ 27 & 1 & 1 & 7 & 27 & 0.9 \\ 27 & 1 & 1 & 8 & 24 & 0.64 \\ 28 & 1 & 1 & 5 & 19 & 9.05 \\ 28 & 1 & 1 & 6 & 16 & 1.85 \\ 28 & 1 & 1 & 7 & 18 & 1.18 \\ 28 & 1 & 1 & 8 & 15 & 1.75 \\ 29 & 1 & 1 & 5 & 19 & 2.2 \\ 29 & 1 & 1 & 6 & 16 & 2.03 \\ 29 & 1 & 1 & 7 & 21 & 1.2 \\ 29 & 1 & 1 & 8 & 18 & 0.62 \\ 30 & 1 & 1 & 5 & 20 & 2.65 \\ 30 & 1 & 1 & 6 & 19 & 31.65 \\ 30 & 1 & 1 & 7 & 18 & 2.1 \\ 30 & 1 & 1 & 8 & 20 & 2.11 \\ \text { Con } & 1 & & & & \end{array}$

Continued on next page. 


$\begin{array}{cccc}\text { FARM } & \text { BALSAMO } & \text { YEAR 2 } & \text { BA BALSAMO YEAR 2 } \\ 1 & 1 & 1 & 22.69 \\ 1 & 1 & 1 & 22.69 \\ 1 & 1 & 1 & 22.69 \\ 1 & 1 & 1 & 22.69 \\ 2 & 1 & 1 & 31.22 \\ 2 & 1 & 1 & 31.22 \\ 2 & 1 & 1 & 31.22 \\ 2 & 1 & 1 & 31.22 \\ 3 & 1 & 1 & 24.10 \\ 3 & 1 & 1 & 24.10 \\ 3 & 1 & 1 & 24.10 \\ 3 & 1 & 1 & 24.10 \\ 4 & 1 & 1 & 22.96 \\ 4 & 1 & 1 & 22.96 \\ 4 & 1 & 1 & 22.96 \\ 4 & 1 & 1 & 22.96 \\ 5 & 1 & 1 & 24.79 \\ 5 & 1 & 1 & 24.79 \\ 5 & 1 & 1 & 24.79 \\ 5 & 1 & 1 & 24.79 \\ 6 & 1 & 1 & 25.25 \\ 6 & 1 & 1 & 25.25 \\ 6 & 1 & 1 & 25.25 \\ 6 & 1 & 1 & 25.25 \\ 7 & 1 & 1 & 30.17 \\ 7 & 1 & 1 & 30.17 \\ 7 & 1 & 1 & 30.17 \\ 7 & 1 & 1 & 30.17 \\ 8 & 1 & 1 & 24.49 \\ 8 & 1 & 1 & 24.49 \\ 8 & 1 & 1 & 24.49 \\ 8 & 1 & 1 & \end{array}$

Continued on next page. 


$\begin{array}{cccc}\text { FARM } & \text { BALSAMO } & \text { YEAR 2 } & \text { BA BALSAMO YEAR 2 } \\ 9 & 1 & 1 & 30.61 \\ 9 & 1 & 1 & 30.61 \\ 9 & 1 & 1 & 30.61 \\ 9 & 1 & 1 & 30.61 \\ 10 & 1 & 1 & 22.96 \\ 10 & 1 & 1 & 22.96 \\ 10 & 1 & 1 & 22.96 \\ 10 & 1 & 1 & 22.96 \\ 11 & 1 & 1 & 18.94 \\ 11 & 1 & 1 & 18.94 \\ 11 & 1 & 1 & 18.94 \\ 11 & 1 & 1 & 18.94 \\ 12 & 1 & 1 & 24.49 \\ 12 & 1 & 1 & 24.49 \\ 12 & 1 & 1 & 24.49 \\ 12 & 1 & 1 & 24.49 \\ 13 & 1 & 1 & 18.37 \\ 13 & 1 & 1 & 18.37 \\ 13 & 1 & 1 & 18.37 \\ 13 & 1 & 1 & 18.37 \\ 14 & 1 & 1 & 18.37 \\ 14 & 1 & 1 & 18.37 \\ 14 & 1 & 1 & 18.37 \\ 14 & 1 & 1 & 18.37 \\ 15 & 1 & 1 & 28.47 \\ 15 & 1 & 1 & 28.47 \\ 15 & 1 & 1 & 28.47 \\ 15 & 1 & 1 & 28.47 \\ 16 & 1 & 1 & 25.25 \\ 16 & 1 & 1 & 25.25 \\ 16 & 1 & 1 & 25.25 \\ 16 & 1 & 1 & 25.25 \\ C 0 & 1 & \end{array}$

Continued on next page. 


\begin{tabular}{|c|c|c|c|}
\hline FARM & BALSAMO & YEAR 2 & BA BALSAMO YEAR 2 \\
\hline 17 & 1 & 1 & 25.71 \\
\hline 17 & 1 & 1 & 25.71 \\
\hline 17 & 1 & 1 & 25.71 \\
\hline 17 & 1 & 1 & 25.71 \\
\hline 18 & 1 & 1 & 17.22 \\
\hline 18 & 1 & 1 & 17.22 \\
\hline 18 & 1 & 1 & 17.22 \\
\hline 18 & 1 & 1 & 17.22 \\
\hline 19 & 1 & 1 & 14.92 \\
\hline 19 & 1 & 1 & 14.92 \\
\hline 19 & 1 & 1 & 14.92 \\
\hline 19 & 1 & 1 & 14.92 \\
\hline 20 & 1 & 1 & 16.83 \\
\hline 20 & 1 & 1 & 16.83 \\
\hline 20 & 1 & 1 & 16.83 \\
\hline 20 & 1 & 1 & 16.83 \\
\hline 21 & 1 & 1 & 22.96 \\
\hline 21 & 1 & 1 & 22.96 \\
\hline 21 & 1 & 1 & 22.96 \\
\hline 21 & 1 & 1 & 22.96 \\
\hline 22 & 1 & 1 & 11.48 \\
\hline 22 & 1 & 1 & 11.48 \\
\hline 22 & 1 & 1 & 11.48 \\
\hline 22 & 1 & 1 & 11.48 \\
\hline 23 & 1 & 1 & 24.49 \\
\hline 23 & 1 & 1 & 24.49 \\
\hline 23 & 1 & 1 & 24.49 \\
\hline 23 & 1 & 1 & 24.49 \\
\hline 24 & 1 & 1 & 18.37 \\
\hline 24 & 1 & 1 & 18.37 \\
\hline 24 & 1 & 1 & 18.37 \\
\hline 24 & 1 & 1 & 18.37 \\
\hline
\end{tabular}

Continued on next page. 


$\begin{array}{cccc}\text { FARM } & \text { BALSAMO } & \text { YEAR 2 } & \text { BA BALSAMO YEAR 2 } \\ 25 & 1 & 1 & 22.96 \\ 25 & 1 & 1 & 22.96 \\ 25 & 1 & 1 & 22.96 \\ 25 & 1 & 1 & 22.96 \\ 26 & 1 & 1 & 22.96 \\ 26 & 1 & 1 & 22.96 \\ 26 & 1 & 1 & 22.96 \\ 26 & 1 & 1 & 22.96 \\ 27 & 1 & 1 & 19.90 \\ 27 & 1 & 1 & 19.90 \\ 27 & 1 & 1 & 19.90 \\ 27 & 1 & 1 & 19.90 \\ 28 & 1 & 1 & 20.66 \\ 28 & 1 & 1 & 20.66 \\ 28 & 1 & 1 & 20.66 \\ 28 & 1 & 1 & 20.66 \\ 29 & 1 & 1 & 22.96 \\ 29 & 1 & 1 & 22.96 \\ 29 & 1 & 1 & 22.96 \\ 29 & 1 & 1 & 22.96 \\ 30 & 1 & 1 & 20.66 \\ 30 & 1 & 1 & 20.66 \\ 30 & 1 & 1 & 20.66 \\ 30 & 1 & 1 & 20.66\end{array}$




\section{Table C.3.}

Complete data set of field study non balsamo cover type 2009

\begin{tabular}{|c|c|c|c|c|}
\hline FARM & NON BALSAMO & YEAR 1 & TREE & DRY WEIGHT( KG) \\
\hline 1 & 0 & 0 & 1 & 0.06 \\
\hline 1 & 0 & 0 & 2 & 0.05 \\
\hline 1 & 0 & 0 & 3 & 0.07 \\
\hline 1 & 0 & 0 & 4 & 0.09 \\
\hline 2 & 0 & 0 & 1 & 0.18 \\
\hline 2 & 0 & 0 & 2 & 0.06 \\
\hline 2 & 0 & 0 & 3 & 0.18 \\
\hline 2 & 0 & 0 & 4 & 0.05 \\
\hline 3 & 0 & 0 & 1 & 0.18 \\
\hline 3 & 0 & 0 & 2 & 0.05 \\
\hline 3 & 0 & 0 & 3 & 0.06 \\
\hline 3 & 0 & 0 & 4 & 0.06 \\
\hline 4 & 0 & 0 & 1 & 0.06 \\
\hline 4 & 0 & 0 & 2 & 0.09 \\
\hline 4 & 0 & 0 & 3 & 0.15 \\
\hline 4 & 0 & 0 & 4 & 0.09 \\
\hline 6 & 0 & 0 & 1 & 0.09 \\
\hline 6 & 0 & 0 & 2 & 0.06 \\
\hline 6 & 0 & 0 & 3 & 0.06 \\
\hline 6 & 0 & 0 & 4 & 0.09 \\
\hline 8 & 0 & 0 & 1 & 0.16 \\
\hline 8 & 0 & 0 & 2 & 0.06 \\
\hline 8 & 0 & 0 & 3 & 0.09 \\
\hline 8 & 0 & 0 & 4 & 0.06 \\
\hline 10 & 0 & 0 & 1 & 0.1 \\
\hline 10 & 0 & 0 & 2 & 0.06 \\
\hline 10 & 0 & 0 & 3 & 0.03 \\
\hline 10 & 0 & 0 & 4 & 0.09 \\
\hline
\end{tabular}

Continued on next page. 


$\begin{array}{ccccc}\text { FARM } & \text { NON BALSAMO } & \text { YEAR } 1 & \text { TREE } & \text { DRY WEIGHT( KG) } \\ 23 & 0 & 0 & 1 & 0.18 \\ 23 & 0 & 0 & 2 & 0.1 \\ 23 & 0 & 0 & 3 & 0.04 \\ 23 & 0 & 0 & 4 & 0.18 \\ 24 & 0 & 0 & 1 & 0.09 \\ 24 & 0 & 0 & 2 & 0.27 \\ 24 & 0 & 0 & 3 & 0.7 \\ 24 & 0 & 0 & 4 & 0.07 \\ 25 & 0 & 0 & 1 & 0.18 \\ 25 & 0 & 0 & 2 & 0.12 \\ 25 & 0 & 0 & 3 & 0.18 \\ 25 & 0 & 0 & 4 & 0.04 \\ 26 & 0 & 0 & 1 & 0.03 \\ 26 & 0 & 0 & 2 & 0.04 \\ 26 & 0 & 0 & 3 & 0.06 \\ 26 & 0 & 0 & 4 & 0.04 \\ 27 & 0 & 0 & 1 & 0.04 \\ 27 & 0 & 0 & 2 & 0.24 \\ 27 & 0 & 0 & 3 & 0.24 \\ 27 & 0 & 0 & 4 & 0.27 \\ 28 & 0 & 0 & 1 & 0.09 \\ 28 & 0 & 0 & 2 & 0.03 \\ 28 & 0 & 0 & 3 & 0.06 \\ 28 & 0 & 0 & 4 & 0.06\end{array}$

Continued on next page. 


\begin{tabular}{|c|c|c|c|c|}
\hline FARM & NON BALSAMO & YEAR 1 & TREE & HEIGHT( M) \\
\hline 1 & 0 & 0 & 1 & 3.2 \\
\hline 1 & 0 & 0 & 2 & 1.9 \\
\hline 1 & 0 & 0 & 3 & 3 \\
\hline 1 & 0 & 0 & 4 & 2.5 \\
\hline 2 & 0 & 0 & 1 & 2.5 \\
\hline 2 & 0 & 0 & 2 & 2.69 \\
\hline 2 & 0 & 0 & 3 & 2.55 \\
\hline 2 & 0 & 0 & 4 & 2.3 \\
\hline 3 & 0 & 0 & 1 & 2.2 \\
\hline 3 & 0 & 0 & 2 & 2.5 \\
\hline 3 & 0 & 0 & 3 & 2.2 \\
\hline 3 & 0 & 0 & 4 & 2.25 \\
\hline 4 & 0 & 0 & 1 & 2.89 \\
\hline 4 & 0 & 0 & 2 & 2.64 \\
\hline 4 & 0 & 0 & 3 & 3 \\
\hline 4 & 0 & 0 & 4 & 2.75 \\
\hline 6 & 0 & 0 & 1 & 2.4 \\
\hline 6 & 0 & 0 & 2 & 2.25 \\
\hline 6 & 0 & 0 & 3 & 1.9 \\
\hline 6 & 0 & 0 & 4 & 3.3 \\
\hline 8 & 0 & 0 & 1 & 3.2 \\
\hline 8 & 0 & 0 & 2 & 3.2 \\
\hline 8 & 0 & 0 & 3 & 3.3 \\
\hline 8 & 0 & 0 & 4 & 3.15 \\
\hline 10 & 0 & 0 & 1 & 3.2 \\
\hline 10 & 0 & 0 & 2 & 2.75 \\
\hline 10 & 0 & 0 & 3 & 2.4 \\
\hline 10 & 0 & 0 & 4 & 3.4 \\
\hline 23 & 0 & 0 & 1 & 2.81 \\
\hline 23 & 0 & 0 & 2 & 3.15 \\
\hline 23 & 0 & 0 & 3 & 2.9 \\
\hline 23 & 0 & 0 & 4 & 2.45 \\
\hline
\end{tabular}

Continued on next page. 


\begin{tabular}{ccccc} 
FARM & NON BALSAMO & YEAR 1 & TREE & HEIGHT( M) \\
24 & 0 & 0 & 1 & 3.2 \\
24 & 0 & 0 & 2 & 2.6 \\
24 & 0 & 0 & 3 & 2.9 \\
24 & 0 & 0 & 4 & 2.75 \\
25 & 0 & 0 & 1 & 1.93 \\
25 & 0 & 0 & 2 & 1.7 \\
25 & 0 & 0 & 3 & 1.65 \\
25 & 0 & 0 & 4 & 1.95 \\
26 & 0 & 0 & 1 & 1.9 \\
26 & 0 & 0 & 2 & 1.7 \\
26 & 0 & 0 & 3 & 2 \\
26 & 0 & 0 & 4 & 1.76 \\
27 & 0 & 0 & 1 & 3.35 \\
27 & 0 & 0 & 2 & 2.5 \\
27 & 0 & 0 & 3 & 3.2 \\
27 & 0 & 0 & 4 & 2.7 \\
28 & 0 & 0 & 1 & 2.75 \\
28 & 0 & 0 & 2 & 3 \\
28 & 0 & 0 & 3 & 3.32 \\
28 & 0 & 0 & 4 & 3.1 \\
\hline
\end{tabular}

Continued on next page. 


\begin{tabular}{|c|c|c|c|c|}
\hline FARM & NON BALSAMO & YEAR 1 & TREE & DIAMETER (CM) \\
\hline 1 & 0 & 0 & 1 & 14 \\
\hline 1 & 0 & 0 & 2 & 14 \\
\hline 1 & 0 & 0 & 3 & 13 \\
\hline 1 & 0 & 0 & 4 & 9 \\
\hline 2 & 0 & 0 & 1 & 9 \\
\hline 2 & 0 & 0 & 2 & 12 \\
\hline 2 & 0 & 0 & 3 & 13 \\
\hline 2 & 0 & 0 & 4 & 8 \\
\hline 3 & 0 & 0 & 1 & 8 \\
\hline 3 & 0 & 0 & 2 & 8 \\
\hline 3 & 0 & 0 & 3 & 8 \\
\hline 3 & 0 & 0 & 4 & 9 \\
\hline 4 & 0 & 0 & 1 & 11 \\
\hline 4 & 0 & 0 & 2 & 9 \\
\hline 4 & 0 & 0 & 3 & 11 \\
\hline 4 & 0 & 0 & 4 & 10 \\
\hline 6 & 0 & 0 & 1 & 12 \\
\hline 6 & 0 & 0 & 2 & 9 \\
\hline 6 & 0 & 0 & 3 & 6 \\
\hline 6 & 0 & 0 & 4 & 8 \\
\hline 8 & 0 & 0 & 1 & 12 \\
\hline 8 & 0 & 0 & 2 & 14 \\
\hline 8 & 0 & 0 & 3 & 16 \\
\hline 8 & 0 & 0 & 4 & 13 \\
\hline 10 & 0 & 0 & 1 & 14 \\
\hline 10 & 0 & 0 & 2 & 13 \\
\hline 10 & 0 & 0 & 3 & 9 \\
\hline 10 & 0 & 0 & 4 & 14 \\
\hline 23 & 0 & 0 & 1 & 26 \\
\hline 23 & 0 & 0 & 2 & 24 \\
\hline 23 & 0 & 0 & 3 & 18 \\
\hline 23 & 0 & 0 & 4 & 16 \\
\hline
\end{tabular}

Continued on next page. 


$\begin{array}{ccccc}\text { FARM } & \text { NON BALSAMO } & \text { YEAR } 1 & \text { TREE } & \text { DIAMETER }(\mathrm{CM}) \\ 24 & 0 & 0 & 1 & 20 \\ 24 & 0 & 0 & 2 & 17 \\ 24 & 0 & 0 & 3 & 24 \\ 24 & 0 & 0 & 4 & 15 \\ 25 & 0 & 0 & 1 & 15 \\ 25 & 0 & 0 & 2 & 13 \\ 25 & 0 & 0 & 3 & 11 \\ 25 & 0 & 0 & 4 & 16 \\ 26 & 0 & 0 & 1 & 13 \\ 26 & 0 & 0 & 2 & 14 \\ 26 & 0 & 0 & 3 & 14 \\ 26 & 0 & 0 & 4 & 12 \\ 27 & 0 & 0 & 1 & 23 \\ 27 & 0 & 0 & 2 & 17 \\ 27 & 0 & 0 & 3 & 19 \\ 27 & 0 & 0 & 4 & 19 \\ 28 & 0 & 0 & 1 & 17 \\ 28 & 0 & 0 & 2 & 16 \\ 28 & 0 & 0 & 3 & 18 \\ 28 & 0 & 0 & 4 & 24\end{array}$

Continued on next page. 


\begin{tabular}{|c|c|c|c|c|}
\hline FARM & NON BALSAMO & YEAR 1 & TREE & LIGHT (KLUX) \\
\hline 1 & 0 & 0 & 1 & 0.89 \\
\hline 1 & 0 & 0 & 2 & 0.59 \\
\hline 1 & 0 & 0 & 3 & 0.62 \\
\hline 1 & 0 & 0 & 4 & 29 \\
\hline 2 & 0 & 0 & 1 & 1.4 \\
\hline 2 & 0 & 0 & 2 & 2 \\
\hline 2 & 0 & 0 & 3 & 4.95 \\
\hline 2 & 0 & 0 & 4 & 3.7 \\
\hline 3 & 0 & 0 & 1 & 0.75 \\
\hline 3 & 0 & 0 & 2 & 1.5 \\
\hline 3 & 0 & 0 & 3 & 18 \\
\hline 3 & 0 & 0 & 4 & 0.7 \\
\hline 4 & 0 & 0 & 1 & 1.15 \\
\hline 4 & 0 & 0 & 2 & 1.05 \\
\hline 4 & 0 & 0 & 3 & 0.9 \\
\hline 4 & 0 & 0 & 4 & 1.7 \\
\hline 6 & 0 & 0 & 1 & 0.8 \\
\hline 6 & 0 & 0 & 2 & 0.35 \\
\hline 6 & 0 & 0 & 3 & 0.72 \\
\hline 6 & 0 & 0 & 4 & 0.72 \\
\hline 8 & 0 & 0 & 1 & 2 \\
\hline 8 & 0 & 0 & 2 & 8.5 \\
\hline 8 & 0 & 0 & 3 & 3.8 \\
\hline 8 & 0 & 0 & 4 & 2.5 \\
\hline 10 & 0 & 0 & 1 & 10 \\
\hline 10 & 0 & 0 & 2 & 0.47 \\
\hline 10 & 0 & 0 & 3 & 0.58 \\
\hline 10 & 0 & 0 & 4 & 0.41 \\
\hline 23 & 0 & 0 & 1 & 2.5 \\
\hline 23 & 0 & 0 & 2 & 5 \\
\hline 23 & 0 & 0 & 3 & 2.83 \\
\hline 23 & 0 & 0 & 4 & 2.25 \\
\hline
\end{tabular}

Continued on next page. 


$\begin{array}{ccccc}\text { FARM } & \text { NON BALSAMO } & \text { YEAR 1 } & \text { TREE } & \text { LIGHT (KLUX) } \\ 24 & 0 & 0 & 1 & 0.3 \\ 24 & 0 & 0 & 2 & 1.3 \\ 24 & 0 & 0 & 3 & 18.98 \\ 24 & 0 & 0 & 4 & 1.3 \\ 25 & 0 & 0 & 1 & 0.63 \\ 25 & 0 & 0 & 2 & 0.3 \\ 25 & 0 & 0 & 3 & 0.72 \\ 25 & 0 & 0 & 4 & 0.78 \\ 26 & 0 & 0 & 1 & 1.31 \\ 26 & 0 & 0 & 2 & 0.9 \\ 26 & 0 & 0 & 3 & 0.71 \\ 26 & 0 & 0 & 4 & 0.7 \\ 27 & 0 & 0 & 1 & 0.53 \\ 27 & 0 & 0 & 2 & 0.71 \\ 27 & 0 & 0 & 3 & 0.45 \\ 27 & 0 & 0 & 4 & 59 \\ 28 & 0 & 0 & 1 & 2.1 \\ 28 & 0 & 0 & 2 & 1.37 \\ 28 & 0 & 0 & 3 & 0.60 \\ 28 & 0 & 0 & 4 & 1.61\end{array}$

Continued on next page. 


\begin{tabular}{|c|c|c|c|}
\hline FARM & NON BALSAMO & YEAR 1 & BA NON BALSAMO YEAR 1 \\
\hline 1 & 0 & 0 & 17.60 \\
\hline 1 & 0 & 0 & 17.60 \\
\hline 1 & 0 & 0 & 17.60 \\
\hline 1 & 0 & 0 & 17.60 \\
\hline 2 & 0 & 0 & 27.55 \\
\hline 2 & 0 & 0 & 27.55 \\
\hline 2 & 0 & 0 & 27.55 \\
\hline 2 & 0 & 0 & 27.55 \\
\hline 3 & 0 & 0 & 22.96 \\
\hline 3 & 0 & 0 & 22.96 \\
\hline 3 & 0 & 0 & 22.96 \\
\hline 3 & 0 & 0 & 22.96 \\
\hline 4 & 0 & 0 & 18.37 \\
\hline 4 & 0 & 0 & 18.37 \\
\hline 4 & 0 & 0 & 18.37 \\
\hline 4 & 0 & 0 & 18.37 \\
\hline 6 & 0 & 0 & 24.49 \\
\hline 6 & 0 & 0 & 24.49 \\
\hline 6 & 0 & 0 & 24.49 \\
\hline 6 & 0 & 0 & 24.49 \\
\hline 8 & 0 & 0 & 27.55 \\
\hline 8 & 0 & 0 & 27.55 \\
\hline 8 & 0 & 0 & 27.55 \\
\hline 8 & 0 & 0 & 27.55 \\
\hline 10 & 0 & 0 & 17.22 \\
\hline 10 & 0 & 0 & 17.22 \\
\hline 10 & 0 & 0 & 17.22 \\
\hline 10 & 0 & 0 & 17.22 \\
\hline 23 & 0 & 0 & 18.37 \\
\hline 23 & 0 & 0 & 18.37 \\
\hline 23 & 0 & 0 & 18.37 \\
\hline 23 & 0 & 0 & 18.37 \\
\hline
\end{tabular}

Continued on next page. 


$\begin{array}{cccc}\text { FARM } & \text { NON BALSAMO } & \text { YEAR 1 } & \text { BA NON BALSAMO YEAR 1 } \\ 24 & 0 & 0 & 16.83 \\ 24 & 0 & 0 & 16.83 \\ 24 & 0 & 0 & 16.83 \\ 24 & 0 & 0 & 16.83 \\ 25 & 0 & 0 & 19.51 \\ 25 & 0 & 0 & 19.51 \\ 25 & 0 & 0 & 19.51 \\ 25 & 0 & 0 & 19.51 \\ 26 & 0 & 0 & 16.07 \\ 26 & 0 & 0 & 16.07 \\ 26 & 0 & 0 & 16.07 \\ 26 & 0 & 0 & 16.07 \\ 27 & 0 & 0 & 9.18 \\ 27 & 0 & 0 & 9.18 \\ 27 & 0 & 0 & 9.18 \\ 27 & 0 & 0 & 9.18 \\ 28 & 0 & 0 & 24.10 \\ 28 & 0 & 0 & 23.42 \\ 28 & 0 & 0 & 23.42 \\ 28 & 0 & 0 & 23.42\end{array}$




\section{Table C.4.}

Complete data set of field study non balsamo cover type 2010

$\begin{array}{ccccc}\text { FARM } & \text { NON BALSAMO } & \text { YEAR } 1 & \text { TREE } & \text { DRY WEIGHT( KG) } \\ 1 & 0 & 1 & 5 & 0.09 \\ 1 & 0 & 1 & 6 & 0.12 \\ 1 & 0 & 1 & 7 & 0.09 \\ 1 & 0 & 1 & 8 & 0.12 \\ 2 & 0 & 1 & 5 & 0.15 \\ 2 & 0 & 1 & 6 & 0.12 \\ 2 & 0 & 1 & 7 & 0.21 \\ 2 & 0 & 1 & 8 & 0.09 \\ 3 & 0 & 1 & 5 & 0.18 \\ 3 & 0 & 1 & 6 & 0.21 \\ 3 & 0 & 1 & 7 & 0.12 \\ 3 & 0 & 1 & 8 & 0.24 \\ 4 & 0 & 1 & 5 & 0.09 \\ 4 & 0 & 1 & 6 & 0.15 \\ 4 & 0 & 1 & 7 & 0.12 \\ 4 & 0 & 1 & 8 & 0.24 \\ 5 & 0 & 1 & 5 & 0.12 \\ 5 & 0 & 1 & 6 & 0.12 \\ 5 & 0 & 1 & 7 & 0.21 \\ 5 & 0 & 1 & 8 & 0.18 \\ 6 & 0 & 1 & 5 & 0.12 \\ 6 & 0 & 1 & 6 & 0.09 \\ 6 & 0 & 1 & 7 & 0.12 \\ 6 & 0 & 1 & 8 & 0.15 \\ 7 & 0 & 1 & 5 & 0.21 \\ 7 & 0 & 1 & 6 & 0.12 \\ 7 & 0 & 1 & 7 & 0.24 \\ 7 & 0 & 1 & 8 & 0.09 \\ 0 & 0 & & & \end{array}$

Continued on next page. 


\begin{tabular}{|c|c|c|c|c|}
\hline FARM & NON BALSAMO & YEAR 1 & TREE & DRY WEIGHT( KG) \\
\hline 8 & 0 & 1 & 5 & 0.09 \\
\hline 8 & 0 & 1 & 6 & 0.12 \\
\hline 8 & 0 & 1 & 7 & 0.06 \\
\hline 8 & 0 & 1 & 8 & 0.09 \\
\hline 9 & 0 & 1 & 5 & 0.27 \\
\hline 9 & 0 & 1 & 6 & 0.09 \\
\hline 9 & 0 & 1 & 7 & 0.21 \\
\hline 9 & 0 & 1 & 8 & 0.49 \\
\hline 10 & 0 & 1 & 5 & 0.24 \\
\hline 10 & 0 & 1 & 6 & 0.31 \\
\hline 10 & 0 & 1 & 7 & 0.09 \\
\hline 10 & 0 & 1 & 8 & 0.24 \\
\hline 11 & 0 & 1 & 5 & 0.18 \\
\hline 11 & 0 & 1 & 6 & 0.09 \\
\hline 11 & 0 & 1 & 7 & 0.18 \\
\hline 11 & 0 & 1 & 8 & 0.09 \\
\hline 12 & 0 & 1 & 5 & 0.27 \\
\hline 12 & 0 & 1 & 6 & 0.18 \\
\hline 12 & 0 & 1 & 7 & 0.18 \\
\hline 12 & 0 & 1 & 8 & 0.37 \\
\hline 13 & 0 & 1 & 5 & 0.4 \\
\hline 13 & 0 & 1 & 6 & 0.55 \\
\hline 13 & 0 & 1 & 7 & 0.49 \\
\hline 13 & 0 & 1 & 8 & 0.31 \\
\hline 14 & 0 & 1 & 5 & 0.21 \\
\hline 14 & 0 & 1 & 6 & 0.24 \\
\hline 14 & 0 & 1 & 7 & 0.18 \\
\hline 14 & 0 & 1 & 8 & 0.24 \\
\hline 15 & 0 & 1 & 5 & 0.21 \\
\hline 15 & 0 & 1 & 6 & 0.18 \\
\hline 15 & 0 & 1 & 7 & 0.21 \\
\hline 15 & 0 & 1 & 8 & 0.15 \\
\hline
\end{tabular}

Continued on next page. 


\begin{tabular}{|c|c|c|c|c|}
\hline FARM & NON BALSAMO & YEAR 1 & TREE & DRY WEIGHT( KG) \\
\hline 16 & 0 & 1 & 5 & 0.15 \\
\hline 16 & 0 & 1 & 6 & 0.18 \\
\hline 16 & 0 & 1 & 7 & 0.18 \\
\hline 16 & 0 & 1 & 8 & 0.09 \\
\hline 17 & 0 & 1 & 5 & 0.06 \\
\hline 17 & 0 & 1 & 6 & 0.09 \\
\hline 17 & 0 & 1 & 7 & 0.09 \\
\hline 17 & 0 & 1 & 8 & 0.37 \\
\hline 18 & 0 & 1 & 5 & 0.43 \\
\hline 18 & 0 & 1 & 6 & 0.24 \\
\hline 18 & 0 & 1 & 7 & 0.52 \\
\hline 18 & 0 & 1 & 8 & 0.09 \\
\hline 19 & 0 & 1 & 5 & 0.34 \\
\hline 19 & 0 & 1 & 6 & 0.31 \\
\hline 19 & 0 & 1 & 7 & 0.09 \\
\hline 19 & 0 & 1 & 8 & 0.12 \\
\hline 20 & 0 & 1 & 5 & 0.24 \\
\hline 20 & 0 & 1 & 6 & 0.24 \\
\hline 20 & 0 & 1 & 7 & 0.24 \\
\hline 20 & 0 & 1 & 8 & 0.21 \\
\hline 21 & 0 & 1 & 5 & 0.27 \\
\hline 21 & 0 & 1 & 6 & 0.58 \\
\hline 21 & 0 & 1 & 7 & 0.21 \\
\hline 21 & 0 & 1 & 8 & 0.12 \\
\hline 22 & 0 & 1 & 5 & 0.18 \\
\hline 22 & 0 & 1 & 6 & 0.24 \\
\hline 22 & 0 & 1 & 7 & 0.27 \\
\hline 22 & 0 & 1 & 8 & 0.27 \\
\hline 23 & 0 & 1 & 5 & 0.27 \\
\hline 23 & 0 & 1 & 6 & 0.37 \\
\hline 23 & 0 & 1 & 7 & 0.43 \\
\hline 23 & 0 & 1 & 8 & 0.06 \\
\hline
\end{tabular}

Continued on next page. 


$\begin{array}{ccccc}\text { FARM } & \text { NON BALSAMO } & \text { YEAR } 1 & \text { TREE } & \text { DRY WEIGHT( KG) } \\ 24 & 0 & 1 & 5 & 0.09 \\ 24 & 0 & 1 & 6 & 0.15 \\ 24 & 0 & 1 & 7 & 0.09 \\ 24 & 0 & 1 & 8 & 0.24 \\ 25 & 0 & 1 & 5 & 0.21 \\ 25 & 0 & 1 & 6 & 0.09 \\ 25 & 0 & 1 & 7 & 0.15 \\ 25 & 0 & 1 & 8 & 0.21 \\ 26 & 0 & 1 & 5 & 0.06 \\ 26 & 0 & 1 & 6 & 0.12 \\ 26 & 0 & 1 & 7 & 0.18 \\ 26 & 0 & 1 & 8 & 0.06 \\ 27 & 0 & 1 & 5 & 0.49 \\ 27 & 0 & 1 & 6 & 0.52 \\ 27 & 0 & 1 & 7 & 0.31 \\ 27 & 0 & 1 & 8 & 0.52 \\ 28 & 0 & 1 & 5 & 0.27 \\ 28 & 0 & 1 & 6 & 0.37 \\ 28 & 0 & 1 & 7 & 0.15 \\ 28 & 0 & 1 & 8 & 0.49 \\ 29 & 0 & 1 & 5 & 0.15 \\ 29 & 0 & 1 & 6 & 0.09 \\ 29 & 0 & 1 & 7 & 0.12 \\ 29 & 0 & 1 & 8 & 0.09 \\ 30 & 0 & 1 & 5 & 0.03 \\ 30 & 0 & 1 & 6 & 0.03 \\ 30 & 0 & 1 & 7 & 0.06 \\ 30 & 0 & 1 & 8 & 0.06 \\ 60 & 0 & & & \end{array}$

Continued on next page. 


\begin{tabular}{|c|c|c|c|c|}
\hline FARM & NON BALSAMO & YEAR 1 & TREE & HEIGHT( M) \\
\hline 1 & 0 & 1 & 5 & 3.25 \\
\hline 1 & 0 & 1 & 6 & 3.34 \\
\hline 1 & 0 & 1 & 7 & 3.02 \\
\hline 1 & 0 & 1 & 8 & 3.45 \\
\hline 2 & 0 & 1 & 5 & 2.83 \\
\hline 2 & 0 & 1 & 6 & 3.04 \\
\hline 2 & 0 & 1 & 7 & 3 \\
\hline 2 & 0 & 1 & 8 & 2.57 \\
\hline 3 & 0 & 1 & 5 & 2.54 \\
\hline 3 & 0 & 1 & 6 & 2.32 \\
\hline 3 & 0 & 1 & 7 & 2.69 \\
\hline 3 & 0 & 1 & 8 & 2.09 \\
\hline 4 & 0 & 1 & 5 & 2.22 \\
\hline 4 & 0 & 1 & 6 & 2.28 \\
\hline 4 & 0 & 1 & 7 & 2.63 \\
\hline 4 & 0 & 1 & 8 & 3.75 \\
\hline 5 & 0 & 1 & 5 & 4.72 \\
\hline 5 & 0 & 1 & 6 & 3.38 \\
\hline 5 & 0 & 1 & 7 & 4.35 \\
\hline 5 & 0 & 1 & 8 & 3.47 \\
\hline 6 & 0 & 1 & 5 & 2.8 \\
\hline 6 & 0 & 1 & 6 & 3.56 \\
\hline 6 & 0 & 1 & 7 & 3.84 \\
\hline 6 & 0 & 1 & 8 & 3.05 \\
\hline 7 & 0 & 1 & 5 & 2.6 \\
\hline 7 & 0 & 1 & 6 & 3 \\
\hline 7 & 0 & 1 & 7 & 3.69 \\
\hline 7 & 0 & 1 & 8 & 3.5 \\
\hline 8 & 0 & 1 & 5 & 2.5 \\
\hline 8 & 0 & 1 & 6 & 4.1 \\
\hline 8 & 0 & 1 & 7 & 2.8 \\
\hline 8 & 0 & 1 & 8 & 2.8 \\
\hline
\end{tabular}

Continued on next page. 


$\begin{array}{ccccc}\text { FARM } & \text { NON BALSAMO } & \text { YEAR } 1 & \text { TREE } & \text { HEIGHT( M) } \\ 9 & 0 & 1 & 5 & 2.9 \\ 9 & 0 & 1 & 6 & 3 \\ 9 & 0 & 1 & 7 & 3.75 \\ 9 & 0 & 1 & 8 & 3.4 \\ 10 & 0 & 1 & 5 & 3.3 \\ 10 & 0 & 1 & 6 & 2.85 \\ 10 & 0 & 1 & 7 & 2.2 \\ 10 & 0 & 1 & 8 & 3.35 \\ 11 & 0 & 1 & 5 & 3 \\ 11 & 0 & 1 & 6 & 2.32 \\ 11 & 0 & 1 & 7 & 3.22 \\ 11 & 0 & 1 & 8 & 1.7 \\ 12 & 0 & 1 & 5 & 3.6 \\ 12 & 0 & 1 & 6 & 3.35 \\ 12 & 0 & 1 & 7 & 3.3 \\ 12 & 0 & 1 & 8 & 3.85 \\ 13 & 0 & 1 & 5 & 3.4 \\ 13 & 0 & 1 & 6 & 3.66 \\ 13 & 0 & 1 & 7 & 3.25 \\ 13 & 0 & 1 & 8 & 2.6 \\ 14 & 0 & 1 & 5 & 4.03 \\ 14 & 0 & 1 & 6 & 4.2 \\ 14 & 0 & 1 & 7 & 2.85 \\ 14 & 0 & 1 & 8 & 2.67 \\ 15 & 0 & 1 & 5 & 3 \\ 15 & 0 & 1 & 6 & 3.2 \\ 15 & 0 & 1 & 7 & 3.4 \\ 15 & 0 & 1 & 8 & 3.16 \\ 15 & 0 & & & \\ 12 & 0 & 0 & 1 & 5\end{array}$

Continued on next page. 


\begin{tabular}{|c|c|c|c|c|}
\hline FARM & NON BALSAMO & YEAR 1 & TREE & HEIGHT( M) \\
\hline 16 & 0 & 1 & 5 & 3.4 \\
\hline 16 & 0 & 1 & 6 & 3.85 \\
\hline 16 & 0 & 1 & 7 & 3.55 \\
\hline 16 & 0 & 1 & 8 & 3.2 \\
\hline 17 & 0 & 1 & 5 & 1.86 \\
\hline 17 & 0 & 1 & 6 & 2.82 \\
\hline 17 & 0 & 1 & 7 & 3.08 \\
\hline 17 & 0 & 1 & 8 & 2.55 \\
\hline 18 & 0 & 1 & 5 & 3.75 \\
\hline 18 & 0 & 1 & 6 & 3.77 \\
\hline 18 & 0 & 1 & 7 & 4.04 \\
\hline 18 & 0 & 1 & 8 & 3.95 \\
\hline 19 & 0 & 1 & 5 & 4.16 \\
\hline 19 & 0 & 1 & 6 & 4.35 \\
\hline 19 & 0 & 1 & 7 & 3.48 \\
\hline 19 & 0 & 1 & 8 & 2.9 \\
\hline 20 & 0 & 1 & 5 & 2.59 \\
\hline 20 & 0 & 1 & 6 & 4 \\
\hline 20 & 0 & 1 & 7 & 3.3 \\
\hline 20 & 0 & 1 & 8 & 2.2 \\
\hline 21 & 0 & 1 & 5 & 3.43 \\
\hline 21 & 0 & 1 & 6 & 4.7 \\
\hline 21 & 0 & 1 & 7 & 3.53 \\
\hline 21 & 0 & 1 & 8 & 3.28 \\
\hline 22 & 0 & 1 & 5 & 4.59 \\
\hline 22 & 0 & 1 & 6 & 4.35 \\
\hline 22 & 0 & 1 & 7 & 4.35 \\
\hline 22 & 0 & 1 & 8 & 4.38 \\
\hline 23 & 0 & 1 & 5 & 2.98 \\
\hline 23 & 0 & 1 & 6 & 2.85 \\
\hline 23 & 0 & 1 & 7 & 4.15 \\
\hline 23 & 0 & 1 & 8 & 3.25 \\
\hline
\end{tabular}

Continued on next page. 


$\begin{array}{ccccc}\text { FARM } & \text { NON BALSAMO } & \text { YEAR 1 } & \text { TREE } & \text { HEIGHT( M) } \\ 24 & 0 & 1 & 5 & 3.37 \\ 24 & 0 & 1 & 6 & 3.29 \\ 24 & 0 & 1 & 7 & 2.93 \\ 24 & 0 & 1 & 8 & 3.11 \\ 25 & 0 & 1 & 5 & 3.58 \\ 25 & 0 & 1 & 6 & 3.89 \\ 25 & 0 & 1 & 7 & 4.47 \\ 25 & 0 & 1 & 8 & 3.9 \\ 26 & 0 & 1 & 5 & 1.97 \\ 26 & 0 & 1 & 6 & 2.62 \\ 26 & 0 & 1 & 7 & 2.57 \\ 26 & 0 & 1 & 8 & 2.05 \\ 27 & 0 & 1 & 5 & 3.2 \\ 27 & 0 & 1 & 6 & 3.45 \\ 27 & 0 & 1 & 7 & 3.25 \\ 27 & 0 & 1 & 8 & 3.03 \\ 28 & 0 & 1 & 5 & 3 \\ 28 & 0 & 1 & 6 & 4.72 \\ 28 & 0 & 1 & 7 & 4 \\ 28 & 0 & 1 & 8 & 4 \\ 29 & 0 & 1 & 5 & 2.05 \\ 29 & 0 & 1 & 6 & 3.04 \\ 29 & 0 & 1 & 7 & 2.5 \\ 29 & 0 & 1 & 8 & 1.92 \\ 30 & 0 & 1 & 5 & 2.7 \\ 30 & 0 & 1 & 6 & 2.6 \\ 30 & 0 & 1 & 7 & 2.45 \\ 30 & 0 & 1 & 8 & 2.85 \\ \text { Co } & 0 & & & \end{array}$

Continued on next page. 


\begin{tabular}{|c|c|c|c|c|}
\hline FARM & NON BALSAMO & YEAR 1 & TREE & DIAMETER (CM) \\
\hline 1 & 0 & 1 & 5 & 20 \\
\hline 1 & 0 & 1 & 6 & 17 \\
\hline 1 & 0 & 1 & 7 & 20 \\
\hline 1 & 0 & 1 & 8 & 18 \\
\hline 2 & 0 & 1 & 5 & 16 \\
\hline 2 & 0 & 1 & 6 & 14 \\
\hline 2 & 0 & 1 & 7 & 16 \\
\hline 2 & 0 & 1 & 8 & 17 \\
\hline 3 & 0 & 1 & 5 & 14 \\
\hline 3 & 0 & 1 & 6 & 17 \\
\hline 3 & 0 & 1 & 7 & 17 \\
\hline 3 & 0 & 1 & 8 & 16 \\
\hline 4 & 0 & 1 & 5 & 11 \\
\hline 4 & 0 & 1 & 6 & 13 \\
\hline 4 & 0 & 1 & 7 & 12 \\
\hline 4 & 0 & 1 & 8 & 18 \\
\hline 5 & 0 & 1 & 5 & 24 \\
\hline 5 & 0 & 1 & 6 & 20 \\
\hline 5 & 0 & 1 & 7 & 20 \\
\hline 5 & 0 & 1 & 8 & 27 \\
\hline 6 & 0 & 1 & 5 & 12 \\
\hline 6 & 0 & 1 & 6 & 12 \\
\hline 6 & 0 & 1 & 7 & 19 \\
\hline 6 & 0 & 1 & 8 & 13 \\
\hline 7 & 0 & 1 & 5 & 14 \\
\hline 7 & 0 & 1 & 6 & 14 \\
\hline 7 & 0 & 1 & 7 & 18 \\
\hline 7 & 0 & 1 & 8 & 15 \\
\hline 8 & 0 & 1 & 5 & 17 \\
\hline 8 & 0 & 1 & 6 & 18 \\
\hline 8 & 0 & 1 & 7 & 14 \\
\hline 8 & 0 & 1 & 8 & 19 \\
\hline
\end{tabular}

Continued on next page. 


$\begin{array}{ccccc}\text { FARM } & \text { NON BALSAMO } & \text { YEAR } 1 & \text { TREE } & \text { DIAMETER (CM) } \\ 9 & 0 & 1 & 5 & 18 \\ 9 & 0 & 1 & 6 & 21 \\ 9 & 0 & 1 & 7 & 22 \\ 9 & 0 & 1 & 8 & 18 \\ 10 & 0 & 1 & 5 & 17 \\ 10 & 0 & 1 & 6 & 15 \\ 10 & 0 & 1 & 7 & 12 \\ 10 & 0 & 1 & 8 & 15 \\ 11 & 0 & 1 & 5 & 15 \\ 11 & 0 & 1 & 6 & 17 \\ 11 & 0 & 1 & 7 & 21 \\ 11 & 0 & 1 & 8 & 16 \\ 12 & 0 & 1 & 5 & 19 \\ 12 & 0 & 1 & 6 & 16 \\ 12 & 0 & 1 & 7 & 19 \\ 12 & 0 & 1 & 8 & 22 \\ 13 & 0 & 1 & 5 & 20 \\ 13 & 0 & 1 & 6 & 21 \\ 13 & 0 & 1 & 7 & 19 \\ 13 & 0 & 1 & 8 & 15 \\ 14 & 0 & 1 & 5 & 19 \\ 14 & 0 & 1 & 6 & 26 \\ 14 & 0 & 1 & 7 & 25 \\ 14 & 0 & 1 & 8 & 17 \\ 15 & 0 & 1 & 5 & 17 \\ 15 & 0 & 1 & 6 & 16 \\ 15 & 0 & 1 & 7 & 17 \\ 15 & 0 & 1 & 8 & 17 \\ 15 & 0 & & & \end{array}$

Continued on next page. 


\begin{tabular}{|c|c|c|c|c|}
\hline FARM & NON BALSAMO & YEAR 1 & TREE & DIAMETER (CM) \\
\hline 16 & 0 & 1 & 5 & 18 \\
\hline 16 & 0 & 1 & 6 & 23 \\
\hline 16 & 0 & 1 & 7 & 26 \\
\hline 16 & 0 & 1 & 8 & 15 \\
\hline 17 & 0 & 1 & 5 & 16 \\
\hline 17 & 0 & 1 & 6 & 15 \\
\hline 17 & 0 & 1 & 7 & 17 \\
\hline 17 & 0 & 1 & 8 & 18 \\
\hline 18 & 0 & 1 & 5 & 24 \\
\hline 18 & 0 & 1 & 6 & 20 \\
\hline 18 & 0 & 1 & 7 & 20 \\
\hline 18 & 0 & 1 & 8 & 29 \\
\hline 19 & 0 & 1 & 5 & 17 \\
\hline 19 & 0 & 1 & 6 & 28 \\
\hline 19 & 0 & 1 & 7 & 25 \\
\hline 19 & 0 & 1 & 8 & 13 \\
\hline 20 & 0 & 1 & 5 & 16 \\
\hline 20 & 0 & 1 & 6 & 19 \\
\hline 20 & 0 & 1 & 7 & 27 \\
\hline 20 & 0 & 1 & 8 & 20 \\
\hline 21 & 0 & 1 & 5 & 23 \\
\hline 21 & 0 & 1 & 6 & 18 \\
\hline 21 & 0 & 1 & 7 & 22 \\
\hline 21 & 0 & 1 & 8 & 17 \\
\hline 22 & 0 & 1 & 5 & 44 \\
\hline 22 & 0 & 1 & 6 & 25 \\
\hline 22 & 0 & 1 & 7 & 25 \\
\hline 22 & 0 & 1 & 8 & 43 \\
\hline 23 & 0 & 1 & 5 & 34 \\
\hline 23 & 0 & 1 & 6 & 18 \\
\hline 23 & 0 & 1 & 7 & 28 \\
\hline 23 & 0 & 1 & 8 & 18 \\
\hline
\end{tabular}

Continued on next page. 


$\begin{array}{ccccc}\text { FARM } & \text { NON BALSAMO } & \text { YEAR } 1 & \text { TREE } & \text { DIAMETER (CM) } \\ 24 & 0 & 1 & 5 & 20 \\ 24 & 0 & 1 & 6 & 35 \\ 24 & 0 & 1 & 7 & 25 \\ 24 & 0 & 1 & 8 & 19 \\ 25 & 0 & 1 & 5 & 19 \\ 25 & 0 & 1 & 6 & 28 \\ 25 & 0 & 1 & 7 & 40 \\ 25 & 0 & 1 & 8 & 23 \\ 26 & 0 & 1 & 5 & 14 \\ 26 & 0 & 1 & 6 & 15 \\ 26 & 0 & 1 & 7 & 20 \\ 26 & 0 & 1 & 8 & 14 \\ 27 & 0 & 1 & 5 & 27 \\ 27 & 0 & 1 & 6 & 20 \\ 27 & 0 & 1 & 7 & 22 \\ 27 & 0 & 1 & 8 & 28 \\ 28 & 0 & 1 & 5 & 20 \\ 28 & 0 & 1 & 6 & 22 \\ 28 & 0 & 1 & 7 & 20 \\ 28 & 0 & 1 & 8 & 22 \\ 29 & 0 & 1 & 5 & 13 \\ 29 & 0 & 1 & 6 & 18 \\ 29 & 0 & 1 & 7 & 18 \\ 29 & 0 & 1 & 8 & 14 \\ 30 & 0 & 1 & 5 & 17 \\ 30 & 0 & 1 & 6 & 21 \\ 30 & 0 & 1 & 7 & 15 \\ 30 & 0 & 1 & 8 & 20 \\ 60 & 0 & & & \end{array}$

Continued on next page. 


\begin{tabular}{|c|c|c|c|c|}
\hline FARM & NON BALSAMO & YEAR 1 & TREE & LIGHT (KLUX) \\
\hline 1 & 0 & 1 & 5 & 0.45 \\
\hline 1 & 0 & 1 & 6 & 0.95 \\
\hline 1 & 0 & 1 & 7 & 1.6 \\
\hline 1 & 0 & 1 & 8 & 7 \\
\hline 2 & 0 & 1 & 5 & 0.35 \\
\hline 2 & 0 & 1 & 6 & 0.4 \\
\hline 2 & 0 & 1 & 7 & 0.4 \\
\hline 2 & 0 & 1 & 8 & 0.26 \\
\hline 3 & 0 & 1 & 5 & 4.25 \\
\hline 3 & 0 & 1 & 6 & 6.46 \\
\hline 3 & 0 & 1 & 7 & 3.88 \\
\hline 3 & 0 & 1 & 8 & 15 \\
\hline 4 & 0 & 1 & 5 & 3.1 \\
\hline 4 & 0 & 1 & 6 & 0.89 \\
\hline 4 & 0 & 1 & 7 & 2.29 \\
\hline 4 & 0 & 1 & 8 & 1.14 \\
\hline 5 & 0 & 1 & 5 & 1.36 \\
\hline 5 & 0 & 1 & 6 & 1.2 \\
\hline 5 & 0 & 1 & 7 & 9 \\
\hline 5 & 0 & 1 & 8 & 1.4 \\
\hline 6 & 0 & 1 & 5 & 0.72 \\
\hline 6 & 0 & 1 & 6 & 1.1 \\
\hline 6 & 0 & 1 & 7 & 1.5 \\
\hline 6 & 0 & 1 & 8 & 1.2 \\
\hline 7 & 0 & 1 & 5 & 1.1 \\
\hline 7 & 0 & 1 & 6 & 6.7 \\
\hline 7 & 0 & 1 & 7 & 4.3 \\
\hline 7 & 0 & 1 & 8 & 0.7 \\
\hline 8 & 0 & 1 & 5 & 0.66 \\
\hline 8 & 0 & 1 & 6 & 0.75 \\
\hline 8 & 0 & 1 & 7 & 7.5 \\
\hline 8 & 0 & 1 & 8 & 3 \\
\hline
\end{tabular}

Continued on next page. 


\begin{tabular}{ccccc} 
FARM & NON BALSAMO & YEAR 1 & TREE & LIGHT (KLUX) \\
9 & 0 & 1 & 5 & 0.75 \\
9 & 0 & 1 & 6 & 0.8 \\
9 & 0 & 1 & 7 & 22.67 \\
9 & 0 & 1 & 8 & 1.02 \\
10 & 0 & 1 & 5 & 0.5 \\
10 & 0 & 1 & 6 & 0.8 \\
10 & 0 & 1 & 7 & 13 \\
10 & 0 & 1 & 8 & 1 \\
11 & 0 & 1 & 5 & 1.33 \\
11 & 0 & 1 & 6 & 15 \\
11 & 0 & 1 & 7 & 5 \\
11 & 0 & 1 & 8 & 20 \\
12 & 0 & 1 & 5 & 2.7 \\
12 & 0 & 1 & 6 & 5.5 \\
12 & 0 & 1 & 7 & 4.5 \\
12 & 0 & 1 & 8 & 2.3 \\
13 & 0 & 1 & 5 & 3.05 \\
13 & 0 & 1 & 6 & 3.6 \\
13 & 0 & 1 & 7 & 2.2 \\
13 & 0 & 1 & 8 & 2.4 \\
14 & 0 & 1 & 5 & 3.5 \\
14 & 0 & 1 & 6 & 1 \\
14 & 0 & 1 & 7 & 1.02 \\
14 & 0 & 1 & 8 & 0.9 \\
15 & 0 & 1 & 5 & 1.8 \\
15 & 0 & 1 & 6 & 2.2 \\
15 & 0 & 1 & 7 & 1.75 \\
15 & 0 & 1 & 8 & 0.69 \\
\hline 0 & 0 & & &
\end{tabular}

Continued on next page. 


\begin{tabular}{|c|c|c|c|c|}
\hline FARM & NON BALSAMO & YEAR 1 & TREE & LIGHT (KLUX) \\
\hline 16 & 0 & 1 & 5 & 1.23 \\
\hline 16 & 0 & 1 & 6 & 1.5 \\
\hline 16 & 0 & 1 & 7 & 3.14 \\
\hline 16 & 0 & 1 & 8 & 3.4 \\
\hline 17 & 0 & 1 & 5 & 6 \\
\hline 17 & 0 & 1 & 6 & 1.4 \\
\hline 17 & 0 & 1 & 7 & 2.42 \\
\hline 17 & 0 & 1 & 8 & 1 \\
\hline 18 & 0 & 1 & 5 & 1.5 \\
\hline 18 & 0 & 1 & 6 & 0.95 \\
\hline 18 & 0 & 1 & 7 & 0.94 \\
\hline 18 & 0 & 1 & 8 & 1.3 \\
\hline 19 & 0 & 1 & 5 & 0.9 \\
\hline 19 & 0 & 1 & 6 & 2.45 \\
\hline 19 & 0 & 1 & 7 & 3.3 \\
\hline 19 & 0 & 1 & 8 & 3.1 \\
\hline 20 & 0 & 1 & 5 & 2.85 \\
\hline 20 & 0 & 1 & 6 & 1.9 \\
\hline 20 & 0 & 1 & 7 & 2.35 \\
\hline 20 & 0 & 1 & 8 & 1.6 \\
\hline 21 & 0 & 1 & 5 & 7.5 \\
\hline 21 & 0 & 1 & 6 & 2.5 \\
\hline 21 & 0 & 1 & 7 & 13 \\
\hline 21 & 0 & 1 & 8 & 6.55 \\
\hline 22 & 0 & 1 & 5 & 3 \\
\hline 22 & 0 & 1 & 6 & 7.51 \\
\hline 22 & 0 & 1 & 7 & 1.75 \\
\hline 22 & 0 & 1 & 8 & 2.15 \\
\hline 23 & 0 & 1 & 5 & 5 \\
\hline 23 & 0 & 1 & 6 & 4.05 \\
\hline 23 & 0 & 1 & 7 & 2.2 \\
\hline 23 & 0 & 1 & 8 & 2.8 \\
\hline
\end{tabular}

Continued on next page. 


$\begin{array}{ccccc}\text { FARM } & \text { NON BALSAMO } & \text { YEAR } 1 & \text { TREE } & \text { LIGHT (KLUX) } \\ 24 & 0 & 1 & 5 & 0.5 \\ 24 & 0 & 1 & 6 & 0.8 \\ 24 & 0 & 1 & 7 & 0.93 \\ 24 & 0 & 1 & 8 & 0.91 \\ 25 & 0 & 1 & 5 & 19 \\ 25 & 0 & 1 & 6 & 0.61 \\ 25 & 0 & 1 & 7 & 1.5 \\ 25 & 0 & 1 & 8 & 0.67 \\ 26 & 0 & 1 & 5 & 1.05 \\ 26 & 0 & 1 & 6 & 3.5 \\ 26 & 0 & 1 & 7 & 1 \\ 26 & 0 & 1 & 8 & 1.5 \\ 27 & 0 & 1 & 5 & 8 \\ 27 & 0 & 1 & 6 & 6 \\ 27 & 0 & 1 & 7 & 6.06 \\ 27 & 0 & 1 & 8 & 0.9 \\ 28 & 0 & 1 & 5 & 1.45 \\ 28 & 0 & 1 & 6 & 20.32 \\ 28 & 0 & 1 & 7 & 0.43 \\ 28 & 0 & 1 & 8 & 0.67 \\ 29 & 0 & 1 & 5 & 20 \\ 29 & 0 & 1 & 6 & 3.07 \\ 29 & 0 & 1 & 7 & 23 \\ 29 & 0 & 1 & 8 & 7.25 \\ 30 & 0 & 1 & 5 & 2.99 \\ 30 & 0 & 1 & 6 & 2.05 \\ 30 & 0 & 1 & 7 & 1.9 \\ 30 & 0 & 1 & 8 & 1.85 \\ C 0 & 0 & & & \end{array}$

Continued on next page. 


\begin{tabular}{|c|c|c|c|}
\hline FARM & NON BALSAMO & YEAR 1 & BA NON BALSAMO YEAR 1 \\
\hline 1 & 0 & 1 & 17.60 \\
\hline 1 & 0 & 1 & 17.60 \\
\hline 1 & 0 & 1 & 17.60 \\
\hline 1 & 0 & 1 & 17.60 \\
\hline 2 & 0 & 1 & 27.55 \\
\hline 2 & 0 & 1 & 27.55 \\
\hline 2 & 0 & 1 & 27.55 \\
\hline 2 & 0 & 1 & 27.55 \\
\hline 3 & 0 & 1 & 22.96 \\
\hline 3 & 0 & 1 & 22.96 \\
\hline 3 & 0 & 1 & 22.96 \\
\hline 3 & 0 & 1 & 22.96 \\
\hline 4 & 0 & 1 & 18.37 \\
\hline 4 & 0 & 1 & 18.37 \\
\hline 4 & 0 & 1 & 18.37 \\
\hline 4 & 0 & 1 & 18.37 \\
\hline 5 & 0 & 1 & 11.48 \\
\hline 5 & 0 & 1 & 11.48 \\
\hline 5 & 0 & 1 & 11.48 \\
\hline 5 & 0 & 1 & 11.48 \\
\hline 6 & 0 & 1 & 24.49 \\
\hline 6 & 0 & 1 & 24.49 \\
\hline 6 & 0 & 1 & 24.49 \\
\hline 6 & 0 & 1 & 24.49 \\
\hline 7 & 0 & 1 & 18.37 \\
\hline 7 & 0 & 1 & 18.37 \\
\hline 7 & 0 & 1 & 18.37 \\
\hline 7 & 0 & 1 & 18.37 \\
\hline 8 & 0 & 1 & 27.55 \\
\hline 8 & 0 & 1 & 27.55 \\
\hline 8 & 0 & 1 & 27.55 \\
\hline 8 & 0 & 1 & 27.55 \\
\hline
\end{tabular}

Continued on next page. 


$\begin{array}{cccc}\text { FARM } & \text { NON BALSAMO } & \text { YEAR 1 } & \text { BA NON BALSAMO YEAR 1 } \\ 9 & 0 & 1 & 22.96 \\ 9 & 0 & 1 & 22.96 \\ 9 & 0 & 1 & 22.96 \\ 9 & 0 & 1 & 22.96 \\ 10 & 0 & 1 & 17.22 \\ 10 & 0 & 1 & 17.22 \\ 10 & 0 & 1 & 17.22 \\ 10 & 0 & 1 & 17.22 \\ 11 & 0 & 1 & 16.83 \\ 11 & 0 & 1 & 16.83 \\ 11 & 0 & 1 & 16.83 \\ 11 & 0 & 1 & 16.83 \\ 12 & 0 & 1 & 18.37 \\ 12 & 0 & 1 & 18.37 \\ 12 & 0 & 1 & 18.37 \\ 12 & 0 & 1 & 18.37 \\ 13 & 0 & 1 & 17.22 \\ 13 & 0 & 1 & 17.22 \\ 13 & 0 & 1 & 17.22 \\ 13 & 0 & 1 & 17.22 \\ 14 & 0 & 1 & 18.37 \\ 14 & 0 & 1 & 18.37 \\ 14 & 0 & 1 & 18.37 \\ 14 & 0 & 1 & 18.37 \\ 15 & 0 & 1 & 13.77 \\ 15 & 0 & 1 & 13.77 \\ 15 & 0 & 1 & 13.77 \\ 15 & 0 & 1 & 13.77 \\ 15 & 0 & & \end{array}$

Continued on next page. 


\begin{tabular}{|c|c|c|c|}
\hline FARM & NON BALSAMO & YEAR 1 & BA NON BALSAMO YEAR 1 \\
\hline 16 & 0 & 1 & 27.55 \\
\hline 16 & 0 & 1 & 27.55 \\
\hline 16 & 0 & 1 & 27.55 \\
\hline 16 & 0 & 1 & 27.55 \\
\hline 17 & 0 & 1 & 9.18 \\
\hline 17 & 0 & 1 & 9.18 \\
\hline 17 & 0 & 1 & 9.18 \\
\hline 17 & 0 & 1 & 9.18 \\
\hline 18 & 0 & 1 & 18.37 \\
\hline 18 & 0 & 1 & 18.37 \\
\hline 18 & 0 & 1 & 18.37 \\
\hline 18 & 0 & 1 & 18.37 \\
\hline 19 & 0 & 1 & 22.30 \\
\hline 19 & 0 & 1 & 22.30 \\
\hline 19 & 0 & 1 & 22.30 \\
\hline 19 & 0 & 1 & 22.30 \\
\hline 20 & 0 & 1 & 18.37 \\
\hline 20 & 0 & 1 & 18.37 \\
\hline 20 & 0 & 1 & 18.37 \\
\hline 20 & 0 & 1 & 18.37 \\
\hline 21 & 0 & 1 & 17.45 \\
\hline 21 & 0 & 1 & 17.45 \\
\hline 21 & 0 & 1 & 17.45 \\
\hline 21 & 0 & 1 & 17.45 \\
\hline 22 & 0 & 1 & 13.77 \\
\hline 22 & 0 & 1 & 13.77 \\
\hline 22 & 0 & 1 & 13.77 \\
\hline 22 & 0 & 1 & 13.77 \\
\hline 23 & 0 & 1 & 18.37 \\
\hline 23 & 0 & 1 & 18.37 \\
\hline 23 & 0 & 1 & 18.37 \\
\hline 23 & 0 & 1 & 18.37 \\
\hline
\end{tabular}

Continued on next page. 


$\begin{array}{cccc}\text { FARM } & \text { NON BALSAMO } & \text { YEAR 1 } & \text { BA NON BALSAMO YEAR 1 } \\ 24 & 0 & 1 & 16.83 \\ 24 & 0 & 1 & 16.83 \\ 24 & 0 & 1 & 16.83 \\ 24 & 0 & 1 & 16.83 \\ 25 & 0 & 1 & 19.51 \\ 25 & 0 & 1 & 19.51 \\ 25 & 0 & 1 & 19.51 \\ 25 & 0 & 1 & 19.51 \\ 26 & 0 & 1 & 16.07 \\ 26 & 0 & 1 & 16.07 \\ 26 & 0 & 1 & 16.07 \\ 26 & 0 & 1 & 16.07 \\ 27 & 0 & 1 & 9.18 \\ 27 & 0 & 1 & 9.18 \\ 27 & 0 & 1 & 9.18 \\ 27 & 0 & 1 & 9.18 \\ 28 & 0 & 1 & 24.10 \\ 28 & 0 & 1 & 24.10 \\ 28 & 0 & 1 & 24.10 \\ 28 & 0 & 1 & 24.10 \\ 29 & 0 & 1 & 18.37 \\ 29 & 0 & 1 & 18.37 \\ 29 & 0 & 1 & 18.37 \\ 29 & 0 & 1 & 18.37 \\ 30 & 0 & 1 & 22.96 \\ 30 & 0 & 1 & 22.96 \\ 30 & 0 & 1 & 22.96 \\ 30 & 0 & 1 & 22.96 \\ & 0 & & \end{array}$




\section{Table C.5.}

Complete data set of basal area in 30 coffee farms

\begin{tabular}{|c|c|}
\hline FARM & BASAL AREA \\
\hline 1 & 21.36 \\
\hline 2 & 30.61 \\
\hline 3 & 23.88 \\
\hline 4 & 20.66 \\
\hline 5 & 20.99 \\
\hline 6 & 24.79 \\
\hline 7 & 28.70 \\
\hline 8 & 26.02 \\
\hline 9 & 22.96 \\
\hline 10 & 19.13 \\
\hline 11 & 18.37 \\
\hline 12 & 20.99 \\
\hline 13 & 18.37 \\
\hline 14 & 18.37 \\
\hline 15 & 22.96 \\
\hline 16 & 26.02 \\
\hline 17 & 22.96 \\
\hline 18 & 17.45 \\
\hline 19 & 19.62 \\
\hline 20 & 17.05 \\
\hline 21 & 19.51 \\
\hline 22 & 11.94 \\
\hline 23 & 20.66 \\
\hline 24 & 17.22 \\
\hline 25 & 20.20 \\
\hline 26 & 21.43 \\
\hline 27 & 14.54 \\
\hline 28 & 23.42 \\
\hline 29 & 19.51 \\
\hline 30 & 21.81 \\
\hline
\end{tabular}




\section{Appendix D - Permissions for Figure 3.4 and Figure 4.7}

Received via email on 25 March 2012

Evan,

Following up on your email, you have my (Steve Anderson) permission to use any of my photos. If you need additional information please let me know.

Steve Anderson 
Figure 2.1

\title{
Library Web Material Usage Statement
}

\author{
Public Domain
}

Materials that are in the public domain (such as images from the Portrait Gallery or most of the maps in the PCL Map Collection), are not copyrighted and no permission is needed to copy them. You may download them and use them as you wish. We appreciate you giving this site credit with the phrase:

"Courtesy of the University of Texas Libraries, The University of Texas at Austin." 